\title{
NON-MEDICAL FACTORS IN THE BACKGROUND OF CESAREAN SECTIONS IN SOUTH-EAST HUNGARY
}

\author{
Ph.D. Thesis
}

Diána Dweik M.D.

Supervisor: Med. habil. Gyula Mészáros, Ph.D.

Department of Obstetrics and Gynecology

Albert Szent-Györgyi Medical Centre

Szeged, 2014 


\section{Publications related to the thesis}

I. Dweik D, Szimjanovszki I, Mészáros G, Pál A. Cesarean delivery on maternal request: Survey among obstetricians/gynecologists in south-east Hungary. (Császármetszés anyai kérésre - ahogyan a délkelet-magyarországi szülésznőgyógyászok látják.) Orv Hetil. 2013,33:1303-11.

II. Dweik D, Girasek E, Töreki A, Mészáros G, Pál A. Women's antenatal preferences for delivery route in a setting with high cesarean section rates and a medically dominated maternity system. Acta Obstet Gynecol Scand. 2014,93:408-15.

III. Dweik D, Girasek E, Töreki A, Mészáros G, Keresztúri A, Pál A. Non-medical determinants of cesarean section in a medically dominated maternity system. Acta Obstet Gynecol Scand. 2014,93:1025-1033. 


\section{Oral presentations and poster presentations related to the thesis}

\section{Oral presentations in Hungarian}

- Dweik D, Mészáros Gy. Császármetszés anyai kérésre? Mit gondolnak a dél-alföldi szülész-nőgyógyászok? Magyar Nőorvos Társaság XXIX. Nagygyülése. Debrecen, 2010. 05. 20-22.

- Dweik D, Mészáros Gy. Császármetszés anyai kérésre? Mit gondolnak a dél-alföldi szülésznők? XVIII. Országos Szülésznői Konferencia. Szeged, 2010. 06. 3-5.

- Dweik D, Mészáros Gy. Császármetszés anyai kérésre? Mit gondolnak a dél-alföldi szülész-nőgyógyászok és szülésznők? PhD Nap. Gyálarét, 2010. 06. 11.

- Dweik D, Mészáros Gy. Császármetszés anyai kérésre? Mit gondolnak a dél-alföldi szülésznők és szülész-nőgyógyászok? Magyar Nőorvos Társaság Dél-Magyarországi Szekciójának XXXI. Kongresszusa. Baja, 2010. 09. 10-11.

- Dweik D. A szüléstöl való félelem a szülés elött, alatt és után. Pszichoszomatika kurzus vizsgaelőadás. Szeged, 2011.05.11.

- Dweik D, Mészáros Gy. Császármetszés anyai kérésre? Mit gondolnak a dél-kelet magyarországi szülésznők, védőnők és szülész-nőgyógyászok? Magyar Pre- és Perinatológiai Pszichológiai és Orvostudományi Társaság XI. Kongresszusa. Budapest, 2011. 11. 4-5.

- Dweik D, Mészáros Gy. Császármetszés anyai kérésre? Mit gondolnak a dél-alföldi szülésznők és szülész-nőgyógyászok? Fiatal Nőorvosok VII. Kongresszusa. OrosházaGyopárosfürdő, 2011. 11. 17-19.

- Dweik D, Mészáros Gy. Császármetszés vs. hüvelyi szülés - hogyan képzelik el a szülést a szegedi várandósok? Országos Magatartástudományi Napok. Szeged, 2012. 05. $14-15$.

- Dweik D. Félelem a szüléstöl, szülési preferencia - Dél-magyarországi attitüdvizsgálat 47. Consilium Trimestre SZTE SzAKK Szülészeti és Nőgyógyászati Klinika. Szeged, 2012. 09.28.

- Dweik D. Szülési preferenciák, félelem a szüléstöl. Psychoszomatikus szülészetnőgyógyászat szakvizsga előkészítő kurzus. Szeged. 2013. 03. 4-5.

- Dweik D, Girasek E, Mészáros Gy. Befolyásolja-e az anyai szülési preferencia a szülés módját? - egy szegedi kérdöives vizsgálat tapasztalatai. Magyar Nőorvos 
Társaság Dél-Magyarországi Szekciójának XXXIV. Kongresszusa. Kecskemét, 2013.10. 4-5.

- Dweik D, Girasek E, Mészáros Gy. Hogyan szeretnének szülni a magyar várandósok? - egy szegedi kérdőíves vizsgálat tapasztalatai. Fiatal Nőorvosok IX. Kongresszusa. Velence 2013. 11. 7-9.

- Dweik D, Girasek E, Mészáros Gy. Nem orvosi szempontok a szülés módjának hátterében - egy szegedi kérdőíves vizsgálat tapasztalatai. Magyar Nőorvos Társaság XXX. Jubileumi Nagygyülése. Pécs, 2014. 05. 22-24.

\section{Oral presentations in English}

- Dweik D, Mészáros Gy. Cesarean Section on Demand - Attitudes of South-East Hungarian Midwives and Obstetricians and Gynecologists. 16th International Congress of the International Society of Psychosomatic Obstetrics and Gynecology. Venice, Italy 2010. 10. 27-30.

- Dweik D, Girasek E, Mészáros Gy. Birth preferences, fear of childbirth and birth outcomes - a South-East Hungarian follow-up survey. 17. International Congress of the International Society of Psychosomatic Obstetrics and Gynaecology. Berlin, 2013. 05. 22-24.

\section{Poster presentations}

- Dweik D, Mészáros Gy. Cesarean Section on Maternal Request - Attitudes of SouthEast Hungarian Obstetricians and Gyencologists. DKMT. Temesvár, 2011.05.30-30.

- Dweik D, Mészáros Gy. Cesarean Section on Maternal Request-Attitudes of SouthEast Hungarian Obstetricians and Gynecologists. Diczfalusy Award Lecture. Szeged, 2011.11.14-15.

- Dweik D, Mészáros Gy. Cesarean Section on Maternal Request - Attitudes of SouthEast Hungarian Obstetricians and Gynecologists.12th International Congress of Behavioral Medicine. Budapest, 2012.08.29-09. 01.

- Dweik D, Mészáros Gy. Caesarean section vs. vaginal delivery - Attitudes and Fears of South-East Hungarian Pregnant Women XX FIGO World Congress. Roma, 2012.10. 5-12. 


\section{List of Abbreviations}

$\mathrm{CS}=$ cesarean section

$\mathrm{CDMR}=$ cesarean delivery on maternal request

FOC $=$ fear of childbirth

VBAC $=$ vaginal birth after cesarean

$\mathrm{VD}=$ vaginal delivery

W-DEQ A = Wijma Delivery Expectancy/Experience Questionnaire A 


\section{Table of Contents}

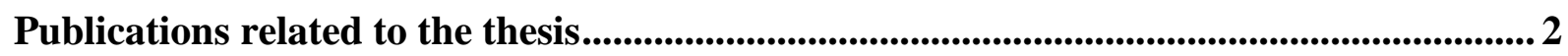

Oral presentations and poster presentations related to the thesis.......................................... 3

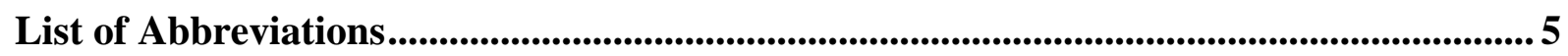

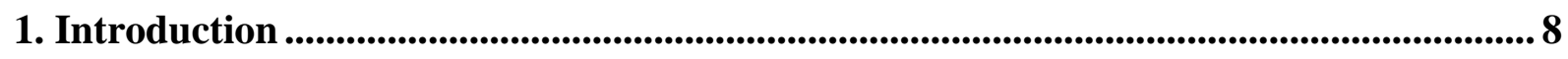

1.1. Cesarean section on demand: maternal request substituting for medical indications.............. 8

1.2. Maternal requests driven by fear of childbirth ............................................................... 10

1.3. Birth context in different countries - an international overview ........................................ 10

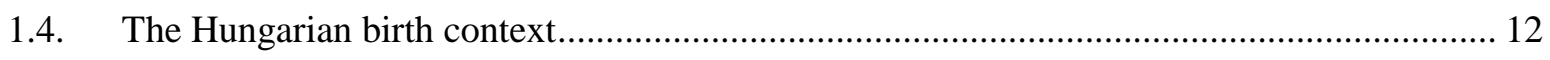

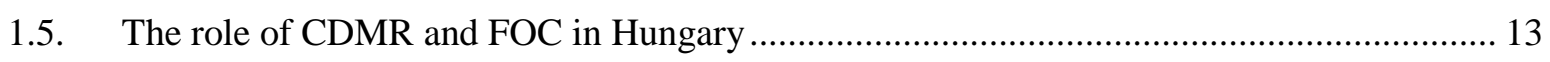

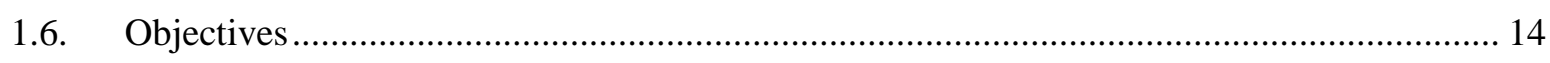

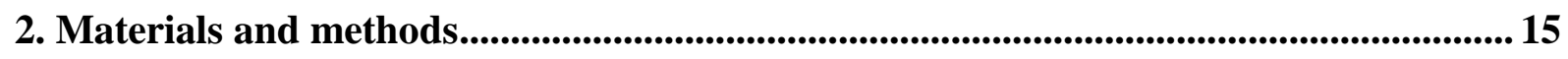

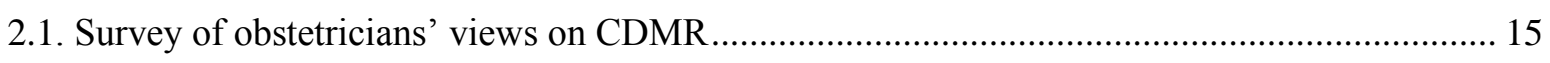

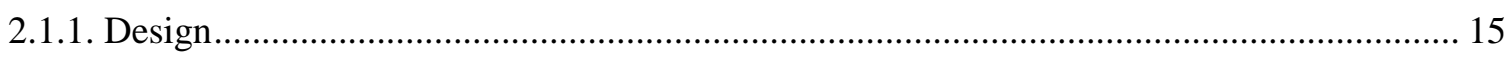

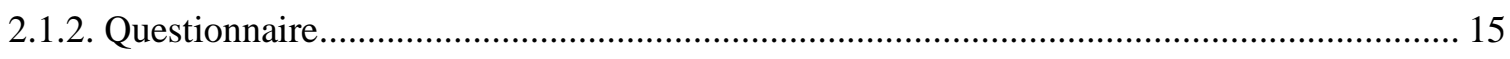

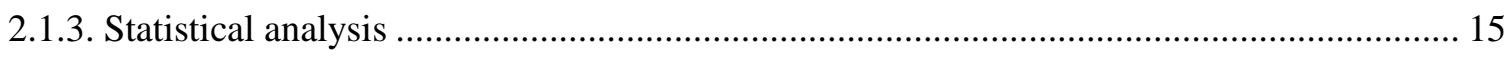

2.2. Survey of pregnant women's childbirth preference and delivery outcome ............................... 16

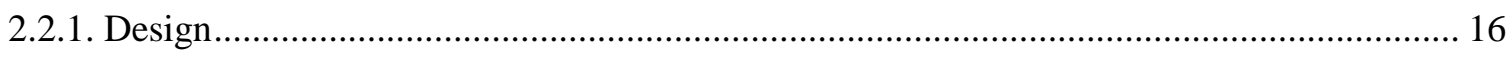

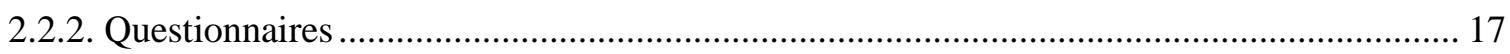

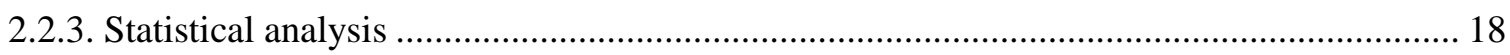

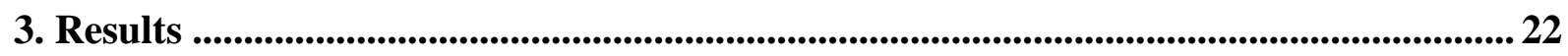

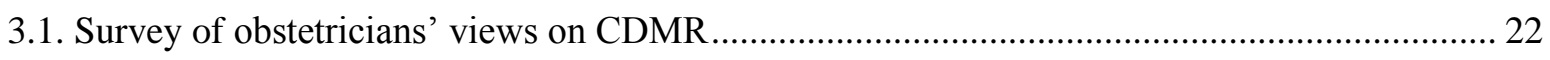

3.2. Pregnant women's childbirth preference and delivery outcome ............................................. 26

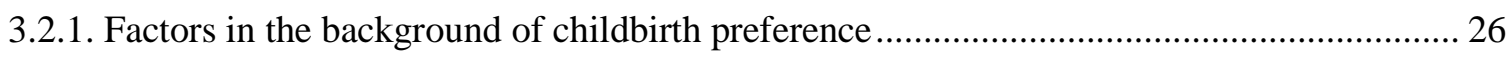

3.2.2. Non-medical factors in the background of mode of delivery ............................................ 30

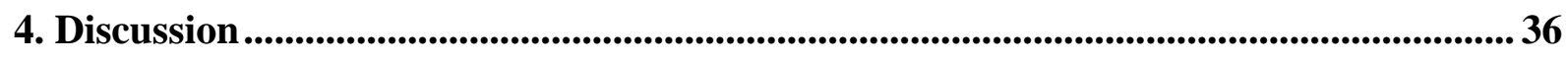

4.1. Ambivalent attitudes of south-east Hungarian obstetricians ................................................... 36

4.2. Determinants of childbirth preference and mode of delivery .................................................. 39

4.2.1. The majority of south-east Hungarian pregnant women prefer VD .................................. 39

4.2.2. The association between childbirth preference, delivery outcome and W-DEQ A scores.. 40

4.2.3. The role of socio-demographic factors and maternal attitudes in shaping childbirth

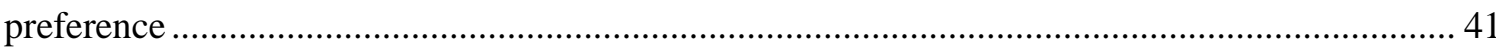

4.2.4. Maternal attitudes, childbirth preferences, socio-demographic characteristics and supplementary obstetric outcome data contributing to mode of delivery 


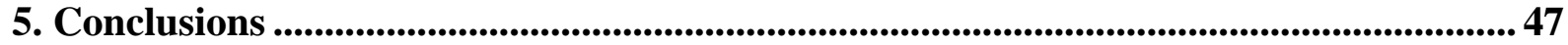

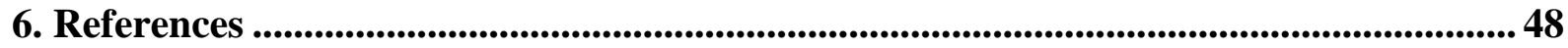

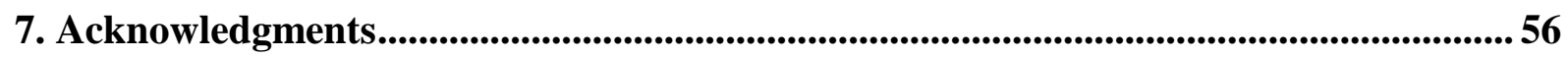

Brief summary in Hungarian (A Doktori Értekezés magyar nyelvű összefoglalása) ...... 57

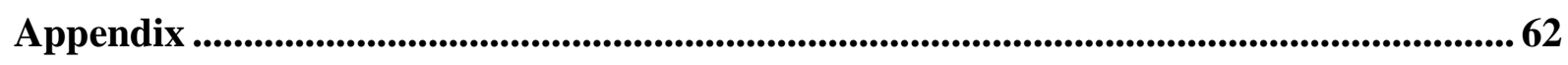

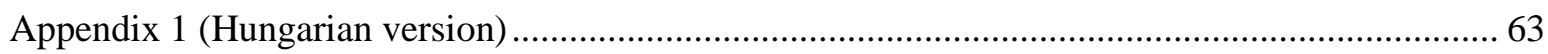

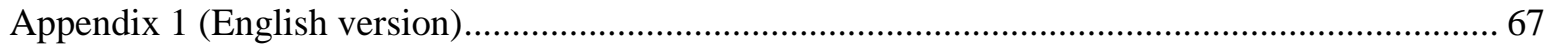

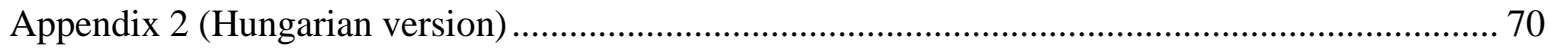

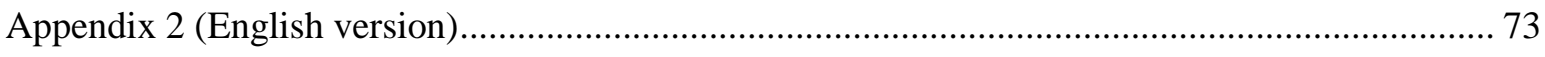

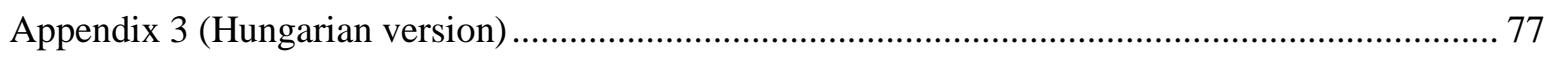

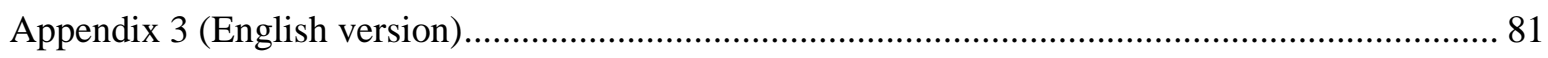

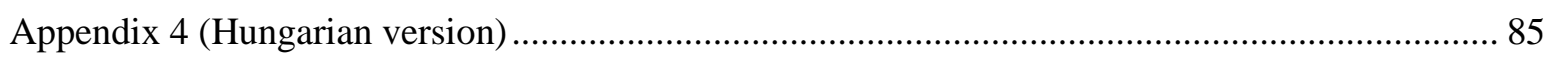

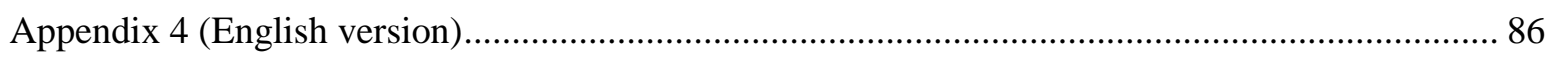




\section{Introduction}

Delivery has always been one of the most highlighted events of women's life everywhere in the world. Until the middle of the $20^{\text {th }}$ century it was an important turningpoint in a woman's and her newborn's life, since perinatal loss (maternal or fetal) was commonplace. Since then enormous changes have occurred in the assessment of childbirthrelated issues, primarily in high-income countries. By the end of the second Millennium healthy mother and newborn have almost become self-evident outcomes of pregnancy and delivery, as a consequence of general socio-economic well-being and the skyrocketing development of medicine. As adequate outcome has been taken for granted, the emphasis of expectations has shifted from 'result' to 'quality'. The issue of delivery circumstances has become one of the most important factors, by which this important event is being assessed. In the era of relatively safe cesarean sections (CS), two previously inconceivable questions emerged, i.e. which way women should and want to deliver their babies - vaginal or abdominal? This thesis is aimed to deal with these questions, based on the answers of southeast Hungarian obstetricians and pregnant women.

\subsection{Cesarean section on demand: maternal request substituting for medical indications}

Hungary has been showing just as high cesarean rates as have evolved in many middle or high resource countries in the $21^{\text {st }}$ century: in $201234.47 \%$ of all deliveries were cesarean sections (1). There has been a steeply rising tendency for CSs since the political transition in the late 1980s, when the rate was $10-11 \%$. This rate, being one of the highest among European countries, is seen by the pessimistic professionals to be only an intermediate stage of a steadily and steeply rising tendency (2). Domestic and international debates concerning the reasons for this epidemic have highlighted numerous contributors to this trend: less risky procedures due to medical development; remarkable demographic changes in the pregnant population; widening of the range of indications for CS that has shifted the formerly lifesaving character of the procedure toward a preventive spectrum; threatening medico-legal environment that has pushed obstetricians into defensive acts (2-4). Beside these factors, the possible role of openly expressed and irrefutable demands of pregnant women has also emerged $(4,5)$. 
The concept of performing 'prophylactic $\mathrm{CS}^{2}$ at term, or as fetal lung maturity is reached, originates back to 1985. Concluding the results of a medico legal case, the authors claimed that this option could enable obstetricians to avoid 'the very real risks associated with passive anticipation of vaginal delivery' $(6,7)$. At that time not much attention was paid to this provocative idea, but since the late 1990s the phenomenon has been an emerging matter of vivid debates all around the world (8-13), albeit, various new designations took the place of the original 'prophylactic CS': cesarean delivery on maternal request (CDMR), patient choice cesarean, cesarean on demand etc.; all ascribing a crucial role to maternal choice.

The definition of CDMR is CS performed electively on maternal request in term following a physiological singleton pregnancy in the absence of any reasonable medical indication (14). However, Kalish et al. called the attention to the entity of intrapartum elective cesarean delivery possibly contributing to the rising number of cesareans performed without medical indication in the U.S. (15). In their study, the option of CS was either offered by the obstetrician or requested by the women before it was medically indicated in a relatively large per cent (13\% and $8 \%$, respectively) of the intrapartum CS cases.

The concept of large quantities of CDMRs in the background of skyrocketing CS rates of many 'Western' countries launched a new generation of studies that investigated the attitudes, beliefs, preferences, needs and fears of expectant mothers. Many of these studies, however, instead of affirming the assumption that large numbers of women are in favor of CS, called the attention to other issues possibly contributing to rising CS rates such as fear of childbirth (FOC), inadequacy of the information giving process, convenience and financial incentives of physicians, and anomalies of different maternity care systems, including women's limited access to midwifery care or their fears of receiving substandard maternity care (16-22). The widespread notion of obstetricians' respect for patient autonomy was also challenged by some studies (19,21-24).

The importance of unveiling the real reasons in the background of worldwide rising rates of CS was highlighted by a World Health Organization Report in 2010. Its authors, based on their calculations, conclude that ' $\mathrm{CS}$ that are possibly, in the large majority at least, medically unnecessary appear to command a disproportionate share of global economic resources' (25). 


\subsection{Maternal requests driven by fear of childbirth}

FOC has been an emerging field of research into birth preferences, birth outcome and rising CS rates (16-17,26-31). It has most thoroughly been investigated in the Nordic states (29-33), where maternity care is known to be putting a greater emphasis on the attitudes, beliefs, fears and concerns of peripartum women, but lately, related studies have been performed among Australian, Dutch, Turkish and even Japanese women (27-28,34-35).

The definition of FOC is anxiety disorder or phobic fear manifesting in nightmares, physical complaints, and difficulties in concentrating on work or on family activities (36-37). It can emerge during pregnancy, delivery and labor or in the postpartum period. Moreover, there is a correlation between ante- and postnatal fear: pregnant women suffering from FOC have higher risk to experience labor and delivery in a negative way, which is often irrespective of mode of delivery (28,31,38-39). Therefore, these conditions compose a higher risk for post partum stress disorder or post partum depression (40). Antenatal FOC is often, but not necessarily, characterized by a request for CS as mode of delivery $(7,36)$. The most characteristic contents of FOC are fear of pain, previous traumatic (birth) experiences, feeling of incompetence for childbirth, and fear of becoming a parent (36). FOC has been shown to be responsible for more painful and prolonged labor and higher risk for emergency CS (1617); however, there are studies that have not confirmed the association between FOC and birth complications (26-28). These conflicting findings and the unlike average FOC levels measured in different populations suggest that the concept of FOC needs to be interpreted within the specific cultural context.

\subsection{Birth context in different countries - an international overview}

Most of the latest studies concerning birth preferences, FOC and CDMR call the attention to the importance of the context where maternity care is provided $(3,18-19)$. Different cultural conceptualization of childbirth is reflected in different maternity care policy and practice (27). Also the dominant practice of maternity care creates a cultural conception of childbirth both in women and their care providers (18).

The Dutch maternity system is famous for its relatively low rates of cesarean sections and high rates of home births, in comparison with other high income countries (41). It is the Dutch midwives responsibility to classify pregnant women to low or high risk pregnancy 
groups. Women in the former group are free to choose the place of birth: home or hospital. Home birth services are run by independent midwifery services (28). The Belgian maternity system, on the other hand, is characterized by a highly medicalized approach, and the vast majority of women consult an obstetrician in the first place (41).

The Nordic states are known of their 'low childbirth intervention rates': in Sweden CS rate was $17 \%$ in 2007, in Finland it was an around $15 \%$ in the first decade of the $21^{\text {st }}$ century $(18,42)$. The publically funded universal health care system does not allow women to freely choose their preferred maternity care models nor their mode of birth: midwives as primary caregivers attend all uncomplicated pregnancies in hospitals, and further remain involved in the delivery in case complications occur $(18,27,42-43)$. Still, on the basis of 'psychosocial indication', CS can be performed without firm medical grounding in Sweden (44); albeit women with a request for CS are referred to counseling services first. The primary aim of these services is to promote a positive birth experience regardless of mode of delivery (45).

Canadian obstetricians work primarily as consultants to family physicians and midwives. This latter group is autonomous, regulated, and the service provided by them is covered by Medicare, regardless of its location (46).

In Australia, maternity system is medically dominated and hospital centered with great emphasis on private care. The national CS rate was $30 \%$ in 2007, in private institutions this rate was $53 \%$ (27). In the same time, women's access to midwifery-led model of maternity care is limited, role of midwives is marginal.

In the U.S. CS rate showed a dramatic rise in the 1970s and 1980s and a moderate decline in the late 1980s, partly due to the breakdown of the prevalent view 'once a cesarean, always a cesarean'. Since 1996 the tendency of steeply increasing CS rates started again, reaching $31.1 \%$ in 2006 , having made the operation the most frequent major surgical procedure for women (47). This increase was due to the increasing numbers of primary CSs and the steep decline in the numbers of vaginal births after cesarean (VBAC) and vaginal breech deliveries $(4,23,48)$. This process launched a nation-wide debate around the possible contribution of CDMRs. The debate has lived on, in spite of the report, which acknowledges that 'no conclusive evidence exists as to whether this [CDMR] is the primary contributor to the increase' (14).

Brazil has one of the highest CS rate in the developing world mostly due to deliveries of women of higher socioeconomic level: in private institutions, this rate was close to $80 \%$ in 2008, the majority of which was shown to be unwanted and many of which was scheduled in advance (20-21). Until the mid-nineties the public health care system paid more for CSs than 
VDs. During this period physicians and hospitals realized that performing CSs is more profitable than conducting VDs, moreover it is convenient and safe. The present situation in Brazil developed due to the negligible amount of social control over the private sector, which allows physicians to attend several deliveries a month. Scheduling more deliveries on the same day helps them to 'gain some measure of control over their lives' (22). Furthermore, in the 1960s midwifery schools became incorporated into nursing education, which resulted in the decline of the once autonomous profession. Parallelly, an expansion of medical schools was seen (20).

After the overview of different maternity systems we need to take a closer look at the Hungarian birth setting, where our studies were performed.

\subsection{The Hungarian birth context}

There are many unique characteristics of the obstetric setting in Hungary: most importantly it is overwhelmingly hospital-based and dominated by obstetricians. The vast majority of deliveries take place at maternity wards of hospitals run by the state, and only a much smaller percent of them in private institutions. After two decades of scandals around out-of-hospital deliveries, home birth became a legal option in 2011 for a minority of healthy pregnant women who opt for a "natural" experience of childbirth. Most of the Hungarian obstetric departments provide primary care. Institutions providing tertiary care are backed by neonatal intensive care units: in general, they have higher numbers of deliveries and higher rates of CSs performed (2). They are supposed to be treating patients with complicated pregnancies (e.g. risk of preterm delivery, severe fetal congenital malformations); however, they also provide primary care.

According to the Textbook of Obstetrics and Gynecology (49) that was in official usage at the time of the beginning of our surveys, only specialists in obstetrics and gynecology were authorized to perform antenatal care and they had to be present at every single delivery regardless of whether it was complicated or not. Apart from the very few legally practicing home-birth services, and one maternity ward in the capital, there is no independent midwifery in Hungary. Therefore, physicians have control over and bear the legal responsibility for obstetric activity, which leads to a remarkable medical dominance. 
According to a new law, from the middle of 2014 midwives will be free to provide ante- and postnatal care; until now this task has been performed by qualified antenatal nurses under the supervision of obstetricians.

Although perinatal care system covers all citizens for free, still, a relatively large per cent of them, almost regardless of health or pregnancy conditions, decide to choose 'private' obstetrician from the very beginning of pregnancy who provides continuous antenatal and postnatal care and is promised to be present at the forthcoming labor and delivery that, in the majority of cases, takes place in one of the publicly funded hospitals. Beside their regular working hours, most of the specialized obstetricians run private praxis and attend their own patients' deliveries. Gaál et al. highlighted obstetric professionals describing the full-blown system of informal payments given by patients to mostly physicians for services ought to be free of charge; a phenomenon that interlaces, and partially contributes to the survival of, the whole Hungarian health care system (50-52).

The last important characteristic of the field of Hungarian obstetrics and gynecology is the gender of physicians. The past decade has shown a slight increase in the number of female obstetricians; however, traditionally it has been a male profession. Furthermore, most of the female obstetricians are too young or still have little professional experience to have a significant impact on decision-making.

\subsection{The role of CDMR and FOC in Hungary}

Officially, pregnant women in Hungary do not have the right to choose elective or intrapartum CS as mode of delivery in the absence of firm medical indications (53). Still, the topic of CSs performed for nonmedical reasons has been a revolving issue of domestic debates (both lay and professional) (2,54-55). However, the contribution of maternal choice to the rising Hungarian CS rate has never been assessed, since, due to the officially non-existing nature of the phenomenon, asking patients or obstetricians directly about whether a CS performed was justified, or looking for missing medical indications in patient files would come up against difficulties. Further difficulties of assessing the prevalence of CDMR were also addressed by two reviews in $2007(19,56)$, suggesting that even the most careful study design cannot guarantee the all-embracing accuracy of any findings regarding this subtle issue. Nevertheless, asking obstetricians and women about their preferences for birth needs to be a crucial part of assessing the contribution of patient choice to CS rates. 
Given the significant differences between the Hungarian and other birth contexts, it is also of interest to investigate how level of FOC may manifest itself in a maternity system where midwifery plays a secondary role and CS rates are higher. Until now, only one study group investigated specific contents of FOC on a sample of Hungarian couples. They highlighted the most important subjects of childbirth-related fear of women, but they did not quantify level of FOC (57).

\subsection{Objectives}

The aims of this thesis are the following:

1. The assessment of the personal opinion of south-east Hungarian obstetricians and gynecologists on CDMR and to reveal their attitudes toward cesarean section vs. vaginal delivery (VD). The reason why the first survey was conducted among obstetricians was that on behalf of the Hungarian maternity system they have the possibility to provide continuous care from conception to the postpartum period. This continuity opens the door to learning about women's beliefs regarding delivery (58). On the other hand, obstetricians' beliefs of the optimal way of giving birth, explicit or implicit they may be, have remarkable impact on patients' views (59). However, it was out of the scope of our survey to reveal the consistency of care providers' knowledge with current evidence. Although it seems to be crucial whether the respondents are aware of the evidence or believe the 'evidence' (46), from the viewpoint of the survey's aims it was a side issue.

2. The assessment of the prevalence of non high-risk pregnant women who, given the chance, would have preferred CS as mode of delivery or were ambivalent in their preference, and to find the difference between these women and those whose preference for vaginal delivery was consistent throughout pregnancy, according to their demographic characteristics, specific attitudes toward birth issues and level of FOC. We also wanted to find the most important factors, apart from medical indications, that determined the actual mode of delivery of women in one of the Hungarian tertiary referral obstetric units, including pregnant women's socio-demographic characteristics, their mid-pregnancy level of FOC, attitudes and preference for mode of childbirth. Our further aim was to enlighten the possible role of organizational issues (staffing, timing) related to the subsequent obstetric outcome. 


\section{Materials and methods}

The research introduced in this thesis was based on two questionnaire surveys and statistical analyses of the data derived. The applied methods of both surveys are discussed separately hereunder.

\subsection{Survey of obstetricians' views on CDMR}

\subsubsection{Design}

In March 2010 structured, anonymous questionnaires (Appendix 1) were passed to each of the 137 obstetricians and gynecologists in the South East Hungarian Region that had almost the same cesarean section rate in 2010 (33.03\%) as the entire country. Most obstetricians worked in hospital maternity wards. A minority of physicians provided antenatal care but was not on-call at delivery ward. The questionnaires were assigned to the 12 obstetric departments in the region (four of which provide tertiary as well as primary obstetric care) via mail. The questionnaires were completed by 102 physicians $(74.5 \%)$ who returned them by post or in person. The survey was approved by the Human Investigation Review Board, University of Szeged, Albert Szent-Györgyi Clinical Centre (No: 51/2010. Date: April 12, 2010).

\subsubsection{Questionnaire}

We used three types of questions the first of which was guesswork, e.g. 'What percentage of nulliparous women at $37^{\text {th }}$ gestational week with singleton normal pregnancy do you think would choose elective cesarean section instead of vaginal delivery in the absence of a firm medical indication, if she had the choice?' The answers to these questions might not be accurate but can be compared. The second type of questions were simple 'yes'/'no'/'cannot decide' questions, e.g. 'Do you think it would be important to have an explicit indication for maternal request cesareans in Hungary?' In the third set of questions a list of statements was given: respondents had to select statements that were concordant with their own strong beliefs.

\subsubsection{Statistical analysis}

The statistical program used was SPSS for Windows 15.0: chi-square test or Fisher's exact test, and independent sample t-test or Mann-Whitney U-test was used in data analysis. Significant differences were indicated when $\mathrm{p}$ values were below 0.05 . 


\subsection{Survey of pregnant women's childbirth preference and delivery outcome}

\subsubsection{Design}

The prospective follow-up study of pregnant women was a part of a broader observational longitudinal questionnaire survey investigating women's beliefs and attitudes from the second trimester of pregnancy to the end of postpartum period with special regard to their birth preferences and level of FOC. The survey was approved by the Human Investigation Review Board, University of Szeged, Albert Szent-Györgyi Clinical Centre (No: 114/2011. Date: Sept 12, 2011). Recruitment of participants took place between November 2011 and March 2012 at the time of routine ultrasound examination in Department of Obstetrics and Gynecology, University of Szeged, Hungary. All 516 women who were invited were in the second trimester between $18^{\text {th }}$ and $22^{\text {nd }}$ gestational weeks. Exclusion criteria were age under 18 years/legal incapacity, illiteracy, not speaking and/or writing Hungarian, bearing high-risk pregnancy (including multiple gestations) or being aware of any true condition that excluded the possibility of subsequent VD. After gaining information on the survey, 503 women gave written consent of participation in the study, and were asked to fill in the first questionnaires (T1). Most women chose to do it while waiting for the ultrasound examination, and only a minority of them chose to return it later on. A total of 488 (94.6\%) questionnaires were suitable for statistical analysis.

Eligible women who rejected to participate reported disinterest $(n=5)$, extreme anxiety about pregnancy because of previous adverse obstetric outcomes, e.g. two previous spontaneous abortions, having an autistic child $(n=4)$, research overload $(n=2)$, being too busy $(n=2)$.

\subsubsection{Prenatal collection of data}

A second questionnaire was completed between 35-37 weeks at the time of a routine cardiotocography examination (T2). Those living further from Szeged and having had this examination in another town received the questionnaire via e-mail or post. At this second time point, between February and July 2012, 427 questionnaires were gained. Reasons for loss to follow up were abortion $(n=4)$, premature labor $(n=14)$, stillbirth $(n=1)$, moving to and delivering in another town $(n=18)$, rejection $(n=12)$, delivering before getting the questionnaire $(n=12)$. A further 14 paired questionnaires were excluded from analysis due to anticipated elective CS because of medical indications learned since T1. Altogether $80.0 \%$ of all invited and $82.1 \%$ of all consenting women, who completed both questionnaires $(n=413)$, 
were included in this analysis. Obstetric background information was gained from case records.

\subsubsection{Postpartum collection of data}

Information on obstetric outcome of those delivering in the department $(n=446)$ was gained from patient files and via personal communication; of those who delivered in another hospital, seven women responded our query regarding factual data of their delivery via postal route or e-mail, thus, altogether $453(87.8 \%)$ women's questionnaires (T1) and obstetric outcome data were analyzed. Beside mode of delivery the following complementary obstetric outcome data were gained: time of day and day of week of delivery; age and gender of the participating obstetrician; if he/she was the patient's private obstetrician; if she/he had the power to indicate cesarean section.

\subsubsection{Questionnaires}

The antenatal questionnaires consisted of three main parts (A,B,C). Questionnaire A was about birth preference and attitudes toward childbirth-issues (Appendix 2). The first topic was addressed by the question: 'As you are heading toward the middle/end of your gestational period, you must have thought about your optimal way of giving birth. Which way would you prefer to deliver your baby, if the decision was up to you?' The two options given were VD and CS. The attitudes toward pregnancy and childbirth-issues were addressed by 33 statements each followed by a six-point Likert scale (ranging from $0=I$ do not agree at all, to $5=I$ absolutely agree). The items were intended to be representing eight distinct dimensions of possible maternal attitudes toward childbirth issues. They were formulated by the authors based on the review of current literature and the previous survey of (60-61) and informal discussions with south-east Hungarian obstetric caregivers. Pilot-testing of the items was performed on 30 pregnant women.

Questionnaire B was the Hungarian translation of Wijma Delivery Expectancy/Experience Questionnaire A (W-DEQ A, 32), a 33-item questionnaire that measures antenatal FOC (Appendix 3). Attainable scores are between 0 and 165, and the higher score on the scale is attained, the higher the level of FOC is. In countries where it has been validated, W-DEQ A score $>80$ indicate moderate FOC, and $>100$ indicate clinically significant FOC. The Hungarian translation of W-DEQ A was performed by the author of this thesis after approval and a copy of the English version was gained from the holder of the copyright (Prof. Klaas Wijma). It has neither been used nor validated in Hungary before the 
present study (validation of the Hungarian translation was not the aim of our survey), therefore we used crude W-DEQ A scores in the analysis.

In questionnaire $\mathrm{C}$ basic socio-demographic data of respondents were obtained in the second trimester and supplementary data in the third trimester (Appendix 4).

\subsubsection{Statistical analysis}

\subsubsection{Analysis of antepartum data}

Statistical analysis of data was performed by using IBM SPSS Statistics Version 20.0. To create variables that better represented the respondents' attitudes and level of FOC throughout pregnancy; we averaged paired variables of questionnaires A and B completed in mid-pregnancy and before delivery. This procedure was feasible because no significant difference was found between the paired attitude variables and fear scores by paired-sample ttest. Cronbach's alpha of the averaged attitude variables was acceptable at 0.735 (62). During the analysis, these attitude variables were grouped according to our initial hypothesis regarding distinct dimensions of attitudes. These dimensions were then confirmed by principal component analysis (Table 1).

From variables regarding preference for birth one combined dichotomous variable was created: respondents either determined in their preference for CS or showing uncertainty composed one group (Group 1) versus those consistent in their preference for VD (Group 2). The mean W-DEQ A scores of the two groups were compared by ANOVA (Analysis of Variance) method.

Birth preference was explained by binary logistic regression models built up by forward conditional variable selection method. The logistic regression method selects independent variables into the model if the particular predefined variable increases the goodness-of-fit of the model. Goodness-of-fit (Nagelkerke R-squared) is the proportion of heterogeneity of childbirth preference explained by the independent variables in the model. Its value might range from 0 to 1 , and the higher it is, the more explanatory power the model has. Positive contribution of an independent variable to a model is detected, when $\operatorname{Exp}(\mathrm{B})>1$, and the contribution is negative when $\operatorname{Exp}(\mathrm{B})<1$. The logistic regression method selected among the following independent variables: principal component variables created from averaged attitude variables, averaged W-DEQ A scores, and main demographic data. Three models 
were built: the first model was based on data from all 413 respondents, while the other two models represented nulliparous $(n=215)$ and parous $(n=198)$ women.

Table 1. Principal components built up of 33 attitude variables (using mean values of paired attitude variables of questionnaire $A$ )

\begin{tabular}{|c|c|c|}
\hline $\begin{array}{c}\text { Principal } \\
\text { components }\end{array}$ & Attitude variables & $\begin{array}{c}\text { component } \\
\text { weight }\end{array}$ \\
\hline 'Being in control' & $\begin{array}{l}\text { I feel that I know almost nothing about what will happen to me on the } \\
\text { day of my delivery. } \\
\text { It is hard for me to cope with uncertainty. } \\
\text { The concept of general anesthesia frightens me. } \\
\text { It does matter to me which day my baby will be born on. }\end{array}$ & $\begin{array}{l}0.609 \\
0.702 \\
0.621 \\
0.443\end{array}$ \\
\hline $\begin{array}{l}\text { 'Right to } \\
\text { autonomy' }\end{array}$ & $\begin{array}{l}\text { I believe that I have the right to make decisions regarding my body } \\
\text { and to choose the way I want to deliver my baby. } \\
\text { You cannot force a woman to be delivering vaginally. }\end{array}$ & $\begin{array}{l}0.809 \\
0.809\end{array}$ \\
\hline $\begin{array}{l}\text { 'In close contact } \\
\text { with the } \\
\text { newborn' }\end{array}$ & $\begin{array}{l}\text { I am looking forward to holding my baby in my arms right after } \\
\text { delivery. } \\
\text { It is very important for me to be able to take care of my baby as soon } \\
\text { as possible after delivery. } \\
\text { I would like to breastfeed. } \\
\text { I would like to experience the moment when my baby is born. }\end{array}$ & $\begin{array}{l}0.703 \\
0.611 \\
0.561\end{array}$ \\
\hline $\begin{array}{l}\text { 'Trust in the } \\
\text { natural way' }\end{array}$ & $\begin{array}{l}\text { I trust my body's implicit knowledge. } \\
\text { I would like to have a delivery as natural as possible. } \\
\text { I feel that everything will be alright with delivery. } \\
\text { I would be very disappointed if I had to deliver by CS. }\end{array}$ & $\begin{array}{l}0.810 \\
0.684 \\
0.688 \\
0.380\end{array}$ \\
\hline $\begin{array}{l}\text { 'Environmental } \\
\text { influence' }\end{array}$ & $\begin{array}{l}\text { I have heard many terrible birth stories of family members and } \\
\text { friends. } \\
\text { My doctor convinced me that CS is the most adequate way for me to } \\
\text { deliver my baby. } \\
\text { Acquaintances and friends of mine recommend CS. } \\
\text { My partner/my family members are worried about what could happen } \\
\text { to me and my baby during VD. }\end{array}$ & $\begin{array}{l}0.433 \\
0.775 \\
0.827 \\
0.828\end{array}$ \\
\hline $\begin{array}{l}\text { 'CS is more } \\
\text { beneficial than } \\
\text { VD' }\end{array}$ & $\begin{array}{l}\text { I believe that CS is the safer way for my baby to be delivered. } \\
\text { In my opinion, it is better for a child to be born vaginally. } \\
\text { I am worried about my sexual life being spoilt after VD. } \\
\text { I am worried that urinary incontinence will develop after VD. } \\
\text { CS is a simple and easy way of delivery. } \\
\text { I believe that being born vaginally is very important for the healthy } \\
\text { psychological development of my baby. }\end{array}$ & $\begin{array}{r}0.835 \\
-0.807 \\
0.515 \\
0.535 \\
0.707 \\
-0.721\end{array}$ \\
\hline $\begin{array}{l}\text { 'Expectations } \\
\text { toward maternity } \\
\text { care' }\end{array}$ & $\begin{array}{l}\text { I have had many bad experiences about health care. } \\
\text { I am sure that I will receive the best care during labor and delivery. } \\
\text { I fear that I will be defenseless during labor and delivery. } \\
\text { I absolutely trust the judgment of obstetricians. } \\
\text { I would like to discuss many issues with the doctor but I feel that he is } \\
\text { always short of time. }\end{array}$ & $\begin{array}{r}0.685 \\
-0.772 \\
0.571 \\
-0.804 \\
0.666\end{array}$ \\
\hline $\begin{array}{c}\text { 'VD, the object of } \\
\text { fear' }\end{array}$ & $\begin{array}{l}\text { I am worried that labor and delivery will be very exhausting. } \\
\text { I am worried that I will not be able to cope with labor pain. } \\
\text { I am worried that I will not be in control during labor and delivery. } \\
\text { I am worried that I will not be able to deliver my baby. }\end{array}$ & $\begin{array}{l}0.815 \\
0.903 \\
0.885 \\
0.723\end{array}$ \\
\hline
\end{tabular}

\footnotetext{
* principal component analysis
} 


\subsubsection{Analysis of peripartum data}

Information on obstetric outcome of those delivering in the department $(n=446)$ was gained through personal contact and from patient files. Of those who delivered in another hospital, seven women responded our query regarding factual data of their delivery via postal route or e-mail. Thus, altogether 453 (87.8\%) women's questionnaires and obstetric outcome data were analyzed. Beside mode of delivery the following supplementary obstetric outcome data were obtained: gestational age at delivery, time of day and day of week of delivery, age and gender of the attending obstetrician, if he/she was the patient's private obstetrician, and whether he/she had the power to decide upon CS.

Statistical analysis of data was performed by using IBM SPSS Statistics Version 20.0. Principal component analysis was used to group maternal attitudes toward childbirth issues, according to our initial hypothesis regarding distinct dimensions of attitudes. Eight principal components were extracted from 32 of the 33 attitude variables by this method (Table 2). Cronbach's alpha of the averaged attitude variables was acceptable at 0.694 (62). From the variable regarding childbirth preference one dichotomous variable was created: respondents either not answering the question or expressing ambiguity and those with explicit preference for CS composed one group versus women preferring VD. Bivariate correlation between childbirth preference, W-DEQ A score and mode of delivery was shown by chi $^{2}$-test and independent-sample t-test. Mode of delivery was then explained by binary logistic regression models built up by forward conditional variable selection method. Goodness-of-fit (Nagelkerke R-squared) value is the proportion of heterogeneity of mode of delivery explained by the independent variables in the model. The logistic regression method selected among the following independent variables: childbirth preference, principal component variables created from attitude variables, W-DEQ A score, main socio-demographic and obstetric history data and supplementary obstetric outcome data. 
Table 2. Principal components built up of 32 attitude variables

\begin{tabular}{|c|c|c|}
\hline Principal components & Attitude variables & $\begin{array}{c}\text { Component } \\
\text { weight* }\end{array}$ \\
\hline \multirow{3}{*}{ 'Being in control' } & \multirow{3}{*}{$\begin{array}{l}\text { I feel that I know almost nothing about what will happen to me on the } \\
\text { day of my delivery. } \\
\text { It is hard for me to cope with uncertainty. } \\
\text { The concept of general anesthesia frightens me. }\end{array}$} & 0.600 \\
\hline & & 0.715 \\
\hline & & 0.636 \\
\hline \multirow[t]{2}{*}{ 'Right to autonomy' } & \multirow{2}{*}{$\begin{array}{l}\text { I believe that I have the right to make decisions regarding my body } \\
\text { and to choose the way I want to deliver my baby. } \\
\text { You cannot force a woman to be delivering vaginally. }\end{array}$} & 0.779 \\
\hline & & 0.779 \\
\hline \multirow{4}{*}{$\begin{array}{l}\text { 'In close contact with } \\
\text { the newborn' }\end{array}$} & \multirow{4}{*}{$\begin{array}{l}\text { I am looking forward to holding my baby in my arms right after } \\
\text { delivery. } \\
\text { It is very important for me to be able to take care of my baby as soon } \\
\text { as possible after delivery. } \\
\text { I would like to breastfeed. } \\
\text { I would like to experience the moment when my baby is born. }\end{array}$} & 0.645 \\
\hline & & 0.707 \\
\hline & & 0.586 \\
\hline & & 0.591 \\
\hline \multirow{4}{*}{$\begin{array}{l}\text { 'Trust in the natural } \\
\text { way' }\end{array}$} & \multirow{4}{*}{$\begin{array}{l}\text { I trust my body's implicit knowledge. } \\
\text { I would like to have a delivery as natural as possible. } \\
\text { I feel that everything will be alright with delivery. } \\
\text { I would be very disappointed if I had to deliver by CS. }\end{array}$} & 0.772 \\
\hline & & 0.661 \\
\hline & & 0.675 \\
\hline & & 0.334 \\
\hline \multirow{4}{*}{$\begin{array}{l}\text { 'Environmental } \\
\text { influence' }\end{array}$} & \multirow{4}{*}{$\begin{array}{l}\text { I have heard many terrible birth stories of family members and } \\
\text { friends. } \\
\text { My doctor convinced me that CS is the most adequate way for me to } \\
\text { deliver my baby. } \\
\text { Acquaintances and friends of mine recommend CS. } \\
\text { My partner/my family members are worried about what could happen } \\
\text { to me and my baby during VD. }\end{array}$} & 0.265 \\
\hline & & 0.742 \\
\hline & & 0.782 \\
\hline & & 0.786 \\
\hline \multirow{6}{*}{$\begin{array}{c}\text { 'CS is more } \\
\text { beneficial than VD' }\end{array}$} & \multirow{6}{*}{$\begin{array}{l}\text { I believe that CS is the safer way for my baby to be delivered. } \\
\text { In my opinion, it is better for a child to be born vaginally. } \\
\text { I am worried about my sexual life being spoilt after VD. } \\
\text { I am worried that urinary incontinence will develop after VD. } \\
\text { CS is a simple and easy way of delivery. } \\
\text { I believe that being born vaginally is very important for the healthy } \\
\text { psychological development of my baby. }\end{array}$} & 0.804 \\
\hline & & -0.775 \\
\hline & & 0.564 \\
\hline & & 0.470 \\
\hline & & 0.674 \\
\hline & & -0.720 \\
\hline \multirow{5}{*}{$\begin{array}{l}\text { 'Expectations toward } \\
\text { maternity care' }\end{array}$} & \multirow{5}{*}{$\begin{array}{l}\text { I have had many bad experiences about health care. } \\
\text { I am sure that I will receive the best care during labor and delivery. } \\
\text { I fear that I will be defenseless during labor and delivery. } \\
\text { I absolutely trust the judgment of obstetricians. } \\
\text { I would like to discuss many issues with the doctor but I feel that he is } \\
\text { always short of time. }\end{array}$} & 0.669 \\
\hline & & -0.738 \\
\hline & & 0.568 \\
\hline & & -0.740 \\
\hline & & 0.619 \\
\hline \multirow{4}{*}{$\begin{array}{c}\text { 'VD, the object of } \\
\text { fear' }\end{array}$} & \multirow{4}{*}{$\begin{array}{l}\text { I am worried that labor and delivery will be very exhausting. } \\
\text { I am worried that I will not be able to cope with labor pain. } \\
\text { I am worried that I will not be in control during labor and delivery. } \\
\text { I am worried that I will not be able to deliver my baby. }\end{array}$} & 0.770 \\
\hline & & 0.848 \\
\hline & & 0.865 \\
\hline & & 0.697 \\
\hline
\end{tabular}

*principal component analysis 


\section{Results}

\subsection{Survey of obstetricians' views on CDMR}

Background data of those completing the questionnaire are shown in Table 3. The ideal CS rate in Hungary would have been 26.5\% ( $\mathrm{SD}=8.76$ ), according to south-east Hungarian obstetricians, but it would have been higher according to respondents in favor of a legal CDMR 'indication' compared with those against it $(29.1 \%$ vs. $24.25 \%$, respectively; $p=$ 0.017). The mean rate of CDMR of all CSs performed in Hungary was estimated to be $10.15 \%$ ( $\mathrm{SD}=10.81$ ), but this rate was higher according to female compared with male obstetricians $(17.5 \%$ vs. $8.9 \%$; $p=0.015)$. Female obstetricians also estimated the percentage of women (nulliparous, over $37^{\text {th }}$ gestational weeks with physiologic pregnancy) preferring CDMR vs. vaginal delivery to be significantly higher than their male counterparts $(40.4 \%$ vs. $25 \%$, respectively; $p=0.012$ ). Average estimated percentage of women in favor of CDMR was $26.8 \%$ ( $\mathrm{SD}=20.16 \%$ ). We could not detect any other demographic characteristics to have an impact on respondents' estimations.

Table 3. Background data of obstetricians $(n=102)$

\begin{tabular}{ccc}
\hline & $\boldsymbol{n}$ & $\boldsymbol{\%}$ \\
Years in practice & 5 & 4.9 \\
$0-5$ & 20 & 19.6 \\
$6-15$ & 20 & 19.6 \\
$16-25$ & 33 & 32.4 \\
$26-35$ & 23 & 22.5 \\
$36 \leq$ & 1 & 1 \\
$\quad$ no response & & \\
Type of department & 59 & 57.8 \\
$\quad$ tertiary & 43 & 42.2 \\
urban hospital & & \\
Main professional field & 83 & 81.3 \\
obstetrics and gynecology & 11 & 10.8 \\
$\quad$ gynecology & 6 & 5.9 \\
$\quad$ obstetrics & 2 & 2 \\
no response & & \\
Authorized to decide upon CS & 79 & 77.5 \\
$\quad$ yes & 23 & 22.5 \\
no & & \\
Gender & 87 & 85.3 \\
$\quad$ male & 14 & 13.7 \\
$\quad$ female & 1 & 1 \\
\hline no response & & \\
& &
\end{tabular}


According to obstetricians, the most important maternal motivations in the background of a request for CDMR were fear of painful and long lasting labor and worry about the wellbeing of the newborn (Table 4). Maternal need for making the most of patient autonomy was also found to be an important motivation. On the other hand, the least important maternal motivations, according to caregivers, were mistrust in health care personnel, previous negative experience regarding health care and pressure on behalf of the private obstetrician. We found no difference between groups of respondents with regard to assessment of maternal motivations.

Table 4. Most important maternal motivations in the background of a maternal wish for CDMR, according to obstetricians $(n=102)$

\begin{tabular}{lcc}
\hline & $\boldsymbol{n}$ & $\boldsymbol{\%}$ \\
\hline Fear of labor pain. & 84 & 82.4 \\
Fear of long-lasting labor. & 61 & 59.8 \\
\hline Finds CS safer than vaginal delivery for the child's health. & 56 & 54.9 \\
\hline Complications in obstetrical and/or family history. & 51 & 50 \\
Thinks she has the right to dispose of her body, e.g. to decide the mode of delivery in & & \\
possession of adequate information. & 44 & 43.1 \\
Fear of damage to or losing pelvic muscle integrity, leading to incontinence or sexual life & 38 & 37.3 \\
disturbance. & 36 & 35.3 \\
\hline Fear of not being able to deliver her baby. & 32 & 31.4 \\
Timing of delivery is easier with CS. & 28 & 27.5 \\
\hline Finds CS safer than vaginal delivery for the mother's health. & 27 & 26.5 \\
Has biased or not adequate information on labor process. & 22 & 21.6 \\
\hline Finds CS a trendy mode of delivery. & 19 & 18.6 \\
\hline Fear of being at the mercy of other people. & 11 & 10.8 \\
\hline Has difficulty tolerating uncertainty, prefers keeping events under absolute control. & 10 & 9.8 \\
Fear of losing control during the labor process. & 10 & 9.8 \\
Has no trust in her body. & & 8.8 \\
Consultations with private obstetrician convinced her that CS is the most adequate mode of & 9 & 5.9 \\
delivery for her. & 6 & 4.9 \\
\hline Previous negative experience regarding health care. & 5 & \\
Mistrust in health care personnel. & & \\
\hline
\end{tabular}

More than half of obstetricians rejected the possibility of an explicit indication for performing CDMR in Hungary. On the other hand, almost one-third of them expressed a need for free maternal choice with regard to mode of delivery (Table 5). Respondents from departments providing tertiary care were more likely to accept the notion of CDMR, compared with those working in urban hospitals: only one-fifth of those supporting this theoretical indication worked in urban hospitals. If there was an existing indication for CDMR in Hungary, eight out of 10 respondents would have felt ready to perform it; furthermore, 12 of them (11.8\% of all respondents) would have even offered the choice of this form of 
delivery to their patients. Obstetricians from tertiary obstetric units were more likely to show willingness to perform a CDMR. Considering only those obstetricians who answered clearly both questions regarding the need for an official CDMR indication and the willingness to perform CDMR $(n=85)$, more than half $(n=39)$ of those saying there is no need for such an indication ( $n=55$ ) would have performed CDMR in a permissive legislative environment. In addition, four-fifth of respondents who found it important not to be regarded as simple technical personnel would have been willing to perform CDMR.

Table 5. Distribution of obstetricians according to their answers to questions regarding a theoretical CDMR indication

$\begin{array}{ccc} & \begin{array}{c}\text { work in } \\ \text { urban } \\ \text { hospital } \\ \text { obstetrician- }\end{array} & \begin{array}{c}\text { work in } \\ \text { tertiary } \\ \text { obstetric } \\ \text { unit } \\ \text { gynecologists }(n=102)\end{array} \\ \begin{array}{ccc}(n=43) \\ n\end{array} \quad \% & n & n\end{array}$

'Do you think it would be necessary to establish an explicit indication for performing CDMR in Hungary (e.g. 'CS on maternal request')?'

\begin{tabular}{lcccc} 
yes & 31 & 30.4 & 6 & 25 \\
no & 57 & 55.9 & 33 & 24 \\
no idea/no response & 14 & 13.7 & $(4)$ & $(10)$ \\
sig.* & & & \multicolumn{2}{c}{$p=0.001$}
\end{tabular}

'Would you be ready to perform and/or suggest CDMR to patients in case the legislation was more permissive in this field?'

$\begin{array}{lcccc}\text { would suggest and perform CDMR } & 12 & 11.8 & 2 & 10 \\ \text { would perform CDMR but would not suggest it } & 69 & 67.6 & 28 & 41 \\ \text { would not perform CDMR } & 17 & 16.7 & 12 & 5 \\ \text { no idea/no response } & 4 & 3.9 & (2) & \text { (2) }\end{array}$

$\begin{array}{ll}\text { sig.* } & p=0.012\end{array}$

$*$ chi $^{2}$-test

Choosing according to their deepest convictions, statements picked by more than half of respondents were without exception in favor of vaginal delivery (Table 6). The least 'popular' statement was about the lack of time needed to achieve an informed consent in case of CDMR. Differences between attitudes of respondent groups according to their opinion on legalized CDMR and their theoretical willingness to perform it can be seen in Table 6 . Significantly larger proportion of respondents expressing explicit willingness to perform CDMR agreed the statements regarding the role of epidemiological changes, lawsuits threatening physicians, easier timing, preserving pelvic floor integrity and the beneficial effect 
of elective $\mathrm{CS}$ on the fetus, compared with the group theoretically rejecting to perform CDMR.

Table 6. Strong beliefs of obstetricians regarding the central issues of obstetrics, according to their attitudes toward a theoretic indication for CDMR

\begin{tabular}{|c|c|c|c|c|c|c|}
\hline $\begin{array}{l}\text { strongly agree } \\
(n=102)\end{array}$ & $\begin{array}{c}\text { in favor } \\
\text { of CDMR } \\
\text { indication } \\
(n=31)\end{array}$ & $\begin{array}{c}\text { against } \\
\text { CDMR } \\
\text { indication } \\
(n=57)\end{array}$ & & $\begin{array}{c}\text { willing to } \\
\text { perform } \\
\text { CDMR } \\
(n=81)\end{array}$ & $\begin{array}{c}\text { not } \\
\text { willing to } \\
\text { perform } \\
\text { CDMR } \\
(n=17)\end{array}$ & \\
\hline$\%$ & $n$ & $n$ & sig.* & $n$ & $n$ & sig.* \\
\hline
\end{tabular}

Pregnancy is not an illness, and vaginal delivery is the natural way of giving birth.
65
63.7
$44 \quad p<0.001$
47
$16 p=0.005$

Recovery is faster after vaginal delivery, thus it is easier for the mother to concentrate totally on the newborn.
64
62.7
12
46
$p<0.001 \quad 48$
$14 \quad p=0.073$

CS might lead to severe complications in the course of subsequent pregnancies and deliveries.
$61 \quad 59.8$
$11 \quad 39 \quad p=0.003$
$14 \quad p=0.026$

I expect my patients to trust my professional skills and judgment and not to regard me merely as a technician or a supplier.
61
59.8
13
$37 p=0.038$
11
$p=0.677$

Hormonal changes during labor are important for the maturation of fetal lungs.

$\begin{array}{llllllll}55 & 53.9 & 13 & 32 & p=0.203 & 43 & 9 & p=0.991\end{array}$

Electively performed CS does not guarantee to escape lawsuits.

$\begin{array}{llllllll}49 & 48 & 12 & 28 & p=0.349 & 39 & 8 & p=0.935\end{array}$

I believe vaginal delivery is safer than elective cesarean for the mother.

$\begin{array}{llllllll}48 & 47.1 & 10 & 30 & p=0.067 & 34 & 11 & p=0.087\end{array}$

Due to the recent epidemiological changes vaginal delivery at the end of a pregnancy is not self-evident any more.

$$
48
$$

19

$21 \quad p=0.028 \quad 40$

$7 \quad p=0.538$

The current trend of lawsuits threatening physicians working in surgical fields, especially obstetricians, leads to the fact that electively performed CS potentially bears smaller threat on my professional

existence compared with vaginal delivery.

$$
\begin{array}{lll}
47 & 46.1 & 19
\end{array}
$$

24

$p=0.085$

40

$5 \quad p=0.133$

Breast feeding is less complicated after vaginal delivery.

Timing of delivery is easier with CS.

$\begin{array}{llllllll}35 & 34.3 & 18 & 13 & p=0.001 & 32 & 2 & p=0.029\end{array}$

I insist on my freedom of judgment that my profession endowed me with.

$\begin{array}{llcccccc}33 & 32.4 & 7 & 20 & p=0.224 & 25 & 6 & p=0.721\end{array}$

I believe elective cesarean is safer than vaginal delivery for the fetus.

$\begin{array}{llllllll}29 & 28.4 & 12 & 13 & p=0.114 & 28 & 1 & p=0.018\end{array}$

I believe CS is more favorable for conserving the integrity and function (i.e. continence, sexual life) of the pelvic floor muscles.

$$
\begin{array}{llllllll}
27 & 26.7 & 14 & 12 & p=0.021 & 25 & 1 & p=0.036
\end{array}
$$

I believe a pregnant woman has the right to dispose of her body, e.g. to decide upon the mode of delivery - in possession of the information needed.

$$
\begin{array}{llllllll}
22 & 21.6 & 17 & 1 & p<0.001 & 21 & 0 & p=0.019
\end{array}
$$

Being born vaginally is an important step in the psychic development of a child.

$$
\begin{array}{llllllll}
22 & 21.6 & 2 & 19 & p=0.005 & 14 & 7 & p=0.047
\end{array}
$$

Due to the latest technical development elective cesarean has become almost as safe as vaginal delivery.

$$
\begin{array}{llllllll}
21 & 20.6 & 10 & 7 & p=0.023 & 19 & 1 & p=0.182
\end{array}
$$

In the long run and in parous women even CS cannot guarantee the conservation of the integrity of the pelvic floor muscles; on the other hand, exercises aiming to keep pelvic floor muscles fit (launched before and right after delivery) are beneficial.
19
18.6
3
$11 p=0.362$
13
$5 \quad p=0.298$ 
Due to the rising number of cesareans physicians and midwives have been lacking adequate skills in vaginal delivery, thus cesarean delivery has become relatively safer.
14
13.7
3
10
$p=0.368$
$2 \quad p=1$

If I performed CDMR without medical indication I would be afraid to be contributing to the negative public opinion towards the representatives of my profession.

\begin{tabular}{|c|c|c|c|c|c|c|c|}
\hline 13 & 12.7 & 0 & 8 & $p=0.046$ & 8 & 4 & $p=0.213$ \\
\hline believe vaginal $\mathrm{d}$ & s saf & 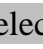 & er & the fetus. & & & \\
\hline 12 & 11.8 & 3 & 8 & $p=0.74$ & 5 & 7 & $p=0.001$ \\
\hline
\end{tabular}

I believe it is my personal responsibility to economize on the sources of national economy: all in all vaginal delivery is cheaper than $\mathrm{CS}$.

$\begin{array}{llllllll}11 & 10.8 & 1 & 8 & p=0.151 & 7 & 2 & p=0.653\end{array}$

Episodes of depression are more likely to develop in those who underwent CS.

$\begin{array}{llllllll}9 & 8.8 & 1 & 5 & p=0.418 & 3 & 3 & p=0.063\end{array}$

I believe elective cesarean is safer than vaginal delivery for the mother .
8
$7.8 \quad 5$
$2 p=0.091$
7
$1 \quad p=1$

The number of my patients would reduce if pregnant women did not have a voice in their mode of delivery.

7

6.9

$5 \quad 2 \quad p=0.090$

7

$0 \quad p=0.349$

I do not have enough time to provide patients with extensive information about all the potential complications of CS, and that would be an elemental requirement of performing CDMR.

$\begin{array}{llllllll}2 & 2 & 0 & 2 & p=0.538 & 17 & 0 & p=1\end{array}$

*chi ${ }^{2}$-test or Fisher's exact test

\subsection{Pregnant women's childbirth preference and delivery outcome}

\subsubsection{Factors in the background of childbirth preference}

Respondents' most important demographic characteristics and expectations regarding delivery are shown in Table 7 . Nulliparous were $52 \%$ of respondents $(n=215)$. The majority of the women were married or cohabiting, and were expecting to be escorted by partner, relative or friend during labor. Most of them were urban residents and graduated from high school. Around two-thirds of women were planning to be seen by 'private' obstetrician, while only a minority was planning to be seen by private midwife. Parous women were significantly older, were more often married and had more often complications in obstetric history than their nulliparous counterparts (data not shown). 
Table 7. Main demographic characteristics and obstetric history data of respondents (n = 413) derived from mid-pregnancy (T1) questionnaire $C$ (except where late pregnancy is indicated, $\mathbf{T 2}$ )

\begin{tabular}{|c|c|c|}
\hline & $n$ & $\%$ \\
\hline \multicolumn{3}{|l|}{ Age (years) } \\
\hline $18-25$ & 79 & 19.1 \\
\hline $26-30$ & 153 & 37 \\
\hline $31-35$ & 130 & 31.5 \\
\hline $36 \leq$ & 51 & 12.3 \\
\hline \multicolumn{3}{|l|}{ Civil status } \\
\hline married & 241 & 58.4 \\
\hline cohabiting & 160 & 38.7 \\
\hline living separately from partner & 12 & 2.9 \\
\hline \multicolumn{3}{|l|}{ Place of residence } \\
\hline urban residence & 309 & 74.8 \\
\hline non-urban residence & 104 & 25.2 \\
\hline \multicolumn{3}{|l|}{ Level of education } \\
\hline 11 years $\geq$ & 82 & 19.9 \\
\hline 11 years $<$ & 331 & 80.1 \\
\hline \multicolumn{3}{|l|}{ Self-rated financial status } \\
\hline below average & 86 & 20.8 \\
\hline average & 270 & 65.4 \\
\hline above average & 57 & 13.8 \\
\hline \multicolumn{3}{|l|}{ Planned pregnancy } \\
\hline yes & 351 & 85 \\
\hline no & 62 & 15 \\
\hline \multicolumn{3}{|l|}{ Decision-to-conception interval } \\
\hline six months $\geq$ & 288 & 69.7 \\
\hline six months< & 125 & 30.3 \\
\hline \multicolumn{3}{|l|}{ Mode of fertilization } \\
\hline spontaneous & 404 & 97.8 \\
\hline insemination, IVF & 9 & 2.2 \\
\hline \multicolumn{3}{|c|}{ Tobacco habits during pregnancy } \\
\hline non-users & 388 & 93.9 \\
\hline users & 25 & 6.1 \\
\hline \multicolumn{3}{|c|}{ Planning to be seen by private obstetrician at delivery* } \\
\hline yes & 276 & 66.8 \\
\hline no & 137 & 33.2 \\
\hline \multicolumn{3}{|c|}{ Planning to be seen by private midwife at delivery* } \\
\hline yes & 60 & 14.5 \\
\hline no & 353 & 85.5 \\
\hline \multicolumn{3}{|l|}{ Previous CS } \\
\hline no & 366 & 88.6 \\
\hline yes & 47 & 11.4 \\
\hline \multicolumn{3}{|c|}{ Complication(s) in obstetric history (apart from CS)** } \\
\hline yes & 43 & 10.4 \\
\hline no & 370 & 89.6 \\
\hline \multicolumn{3}{|c|}{ Expects to be unaccompanied at delivery* } \\
\hline no & 373 & 90.3 \\
\hline yes & 40 & 9.7 \\
\hline \multicolumn{3}{|c|}{$\begin{array}{l}\text { *asked in late pregnancy (T2), ** previous assisted VD, } \\
\text { or/and infertility, or/and premature labor, or/and stillbirth, } \\
\text { or/and at least two of the following conditions: } \\
\text { miscarriage, extra uterine gravidity, missed abortion, } \\
\text { induced abortion due to medical reasons }\end{array}$} \\
\hline
\end{tabular}


Mid-pregnancy preference for CS was stated by $6.5 \%(n=28)$ of all women. At term this was $7.5 \%(n=31)$. Three and five respondents, respectively, showed uncertain preference. There was no significant difference between nulliparous and parous women's birth preference. The distribution of combined childbirth preferences is shown in Table 8 . Almost $90 \%$ of respondents were consistent in preferring VD. More than half of respondents from Group 1 were parous who underwent previous CS (26/48). More than half of women with previous CS (26/47), but less than $10 \%$ of nulliparous women and only three parous women without previous CS were in Group 1.

Table 8. Combined preference for childbirth among nulliparous and parous women (Group 1: preference for CS, unstable preference or uncertainty; Group 2: consistent preference for $V D$ )

\begin{tabular}{lcccccc}
\hline & \multicolumn{2}{c}{$\begin{array}{c}\text { Nulliparous } \\
(\boldsymbol{n}=\mathbf{2 1 5})\end{array}$} & \multicolumn{2}{c}{$\begin{array}{c}\text { Parous } \\
(\boldsymbol{n}=\mathbf{1 9 8})\end{array}$} & \multicolumn{2}{c}{ Total } \\
& $\boldsymbol{n}=\mathbf{4 1 3})$ \\
$\begin{array}{l}\text { Group 1 } \\
(\boldsymbol{n}=\mathbf{4 8})\end{array}$ & 19 & 8.8 & 29 & 14.6 & 48 & 11.6 \\
$\begin{array}{l}\text { Group 2 } \\
(\boldsymbol{n}=\mathbf{3 6 5})\end{array}$ & 196 & 91.2 & 169 & 85.4 & 365 & 88.4 \\
sig.* & \multicolumn{3}{c}{$\mathrm{p}=0.066$} \\
\hline *hi ${ }^{2}$-test
\end{tabular}

W-DEQ A scores were significantly higher in both trimesters in Group 1 compared with Group 2, and this difference remained significant when the averaged W-DEQ A scores were used (Table 9).

Table 9. Mean W-DEQ A scores of respondents of Group 1 (respondents with preference for CS, unstable or uncertain preference) and Group 2 (respondents with consistent preference for $\mathrm{VD}$ )

\begin{tabular}{llccc}
\hline & & $\begin{array}{c}\text { mid- } \\
\text { pregnancy } \\
\text { (T1) }\end{array}$ & $\begin{array}{c}\text { late } \\
\text { pregnancy }\end{array}$ & \\
& & (T2) & average \\
Group 1 & Mean & 62.50 & 63.71 & 63.10 \\
$(\boldsymbol{n}=\mathbf{4 8})$ & SD & 21.94 & 23.18 & 20.86 \\
Group 2 & Mean & 49.75 & 50.24 & 49.99 \\
$(\boldsymbol{n}=\mathbf{3 6 5})$ & SD & 20.36 & 21.85 & 19.61 \\
Total & Mean & 51.23 & 51.81 & 51.52 \\
$(\boldsymbol{n}=\mathbf{4 1 3})$ & SD & 20.93 & 22.40 & 20.17 \\
sig. $*$ & & $p=0.038$ & $p=0.037$ & $p=0.043$ \\
\hline *ANOVA method & & &
\end{tabular}


Three variables contributed independently to the first logistic regression model aimed to explain preference for CS and/or uncertain preference (Table 10). Positive impact of principal component ' $\mathrm{CS}$ is more beneficial than VD' and variable 'previous $\mathrm{CS}$ ' was detected, while principal component 'Trust in the natural way' contributed negatively to the multivariate model. In the third step the goodness-of-fit was 0.619 . The model of nulliparous respondents showed slightly lower goodness-of-fit (0.599). Three variables had a significant impact on childbirth preference: principal component ' $\mathrm{CS}$ is more beneficial than VD' showed considerably strong positive impact $(\operatorname{Exp}(B)=13.606)$, and principal component 'Environmental influence' also contributed positively while principal component 'Being in control' contributed negatively to the model describing preference for CS and/or uncertain preference. The highest goodness-of-fit value (0.716) was in the model for parous women: each variable in the model had strong positive contribution to preference for CS and/or uncertain preference, with the strongest impact of previous CS. 
Table 10. Three multiple logistic regression models built up by forward conditional variable selection method explaining preference for CS or uncertainty regarding preferred mode of delivery

\begin{tabular}{|c|c|c|c|c|c|c|}
\hline \multicolumn{7}{|c|}{ Total $(n=413)$} \\
\hline sig. & & $\begin{array}{l}0.000 \\
0.560\end{array}$ & & 0.000 & & 0.000 \\
\hline variables & sig. & $\operatorname{Exp}(B)$ & sig. & $\operatorname{Exp}(\mathbf{B})$ & sig. & $\operatorname{Exp}(B)$ \\
\hline Principal component 'CS is more & 0.000 & 9.160 & 0.000 & 7.234 & 0.000 & 5.561 \\
\hline Previous CS & & & 0.000 & 6.112 & 0.039 & 6.166 \\
\hline $\begin{array}{l}\text { Principal component 'Trust in the } \\
\text { natural way' }\end{array}$ & & & & & 0.000 & .606 \\
\hline \multicolumn{7}{|c|}{ Nulliparous $(n=215)$} \\
\hline sig. & & 0.000 & & 0.000 & & 0.000 \\
\hline Nagelkerke & & 0.503 & & 0.557 & & 0.599 \\
\hline variables & sig. & $\operatorname{Exp}(B)$ & sig. & $\operatorname{Exp}(\mathbf{B})$ & sig. & $\operatorname{Exp}(B)$ \\
\hline $\begin{array}{l}\text { Principal component 'CS is more } \\
\text { beneficial than VD' }\end{array}$ & 0.000 & 11.717 & 0.000 & 18.854 & 0.000 & 13.606 \\
\hline Principal component 'Being in control' & & & 0.017 & .364 & 0.004 & .220 \\
\hline $\begin{array}{l}\text { Principal component 'Environmental } \\
\text { influence' }\end{array}$ & & & & & 0.025 & 2.574 \\
\hline \multicolumn{7}{|c|}{ Parous $(n=198)$} \\
\hline & & 0.000 & & 0.000 & & 0.000 \\
\hline Nagelkerke R-squared & & 0.622 & & 0.691 & & 0.716 \\
\hline variable & sig. & $\operatorname{Exp}(B)$ & sig. & $\operatorname{Exp}(\mathbf{B})$ & sig. & $\operatorname{Exp}(\mathbf{B})$ \\
\hline $\begin{array}{l}\text { Principal component 'CS is more } \\
\text { beneficial than VD' }\end{array}$ & 0.000 & 7.576 & 0.000 & 4.631 & 0.000 & 4.912 \\
\hline Previous CS & & & 0.001 & 11.063 & 0.001 & 12.996 \\
\hline $\begin{array}{l}\text { Principal component 'Expectations } \\
\text { toward maternity care' }\end{array}$ & & & & & & \\
\hline \multicolumn{7}{|c|}{$\begin{array}{l}\text { Logistic regression, forward (Conditional) method. Dependent variable: Childbirth preference } 0= \\
\text { VD, } 1 \text { = CS or uncertain preference. Independent variables: principal component 'Being in control'; } \\
\text { principal component 'Right to autonomy'; principal component 'In close contact with the newborn'; } \\
\text { principal component 'Trust in the natural way'; principal component 'Environmental influence'; } \\
\text { principal component 'CS is more beneficial than VD'; principal component 'Expectations toward } \\
\text { maternity care'; principal component 'VD, the object of fear'; mean W-DEQ A score; parity; } \\
\text { expecting to be seen by private obstetrician or not; expecting to be seen by private midwife or not; } \\
\text { level of education (in years); place of residence; self-rated financial status; tobacco habits; age (in } \\
\text { years); civil status; planned pregnancy; decision-to-conception interval; mode of fertilization; } \\
\text { previous CS; other complications in obstetric history; expecting to be unaccompanied at delivery. }\end{array}$} \\
\hline
\end{tabular}

\subsubsection{Non-medical factors in the background of mode of delivery}

Most important socio-demographic and obstetric history data of nulliparous and parous respondents derived in mid-pregnancy are shown in Table 11. 
Table 11. Main demographic characteristics and most important obstetric history data of nulliparous and parous respondents in mid-pregnancy

\begin{tabular}{|c|c|c|c|c|c|}
\hline & \multicolumn{2}{|c|}{$\begin{array}{c}\text { Nulliparous } \\
n=237\end{array}$} & \multicolumn{2}{|c|}{$\begin{array}{l}\text { Parous } \\
n=216\end{array}$} & \multirow[t]{2}{*}{ sig." } \\
\hline & $n$ & $\%$ & $n$ & $\%$ & \\
\hline \multicolumn{6}{|l|}{ Age (years) } \\
\hline $18-25$ & 62 & 26.2 & 22 & 10.2 & \multirow{4}{*}{$p<0.001$} \\
\hline $26-30$ & 105 & 44.3 & 61 & 28.2 & \\
\hline $31-35$ & 51 & 21.5 & 94 & 43.5 & \\
\hline $36 \leq$ & 19 & 8 & 39 & 18.1 & \\
\hline \multicolumn{6}{|l|}{ Civil status } \\
\hline married & 110 & 46.4 & 148 & 68.5 & \multirow{3}{*}{$p<0.001$} \\
\hline cohabiting & 120 & 50.6 & 62 & 28.7 & \\
\hline $\begin{array}{l}\text { living separately from } \\
\text { partner }\end{array}$ & 7 & 3 & 6 & 2.8 & \\
\hline \multicolumn{6}{|l|}{ Place of residence } \\
\hline urban residence & 173 & 73 & 161 & 74.5 & \multirow{2}{*}{$p=0.710$} \\
\hline non-urban residence & 64 & 27 & 55 & 25.5 & \\
\hline \multicolumn{6}{|l|}{ Level of education } \\
\hline$\leq 11$ years & 41 & 17.3 & 47 & 21.8 & \multirow{2}{*}{$p=0.231$} \\
\hline$>11$ years & 196 & 82.7 & 169 & 78.2 & \\
\hline \multicolumn{6}{|c|}{ Self-rated financial status } \\
\hline below average & 52 & 21.9 & 42 & 19.4 & \multirow{3}{*}{$p=0.770$} \\
\hline average & 153 & 64.6 & 146 & 67.6 & \\
\hline \multicolumn{5}{|l|}{$\begin{array}{l}\text { Planned } \\
\text { pregnancy }\end{array}$} & \\
\hline yes & 206 & 86.9 & 179 & 82.9 & \multirow{2}{*}{$p=0.228$} \\
\hline no & 31 & 13.1 & 37 & 17.1 & \\
\hline \multicolumn{6}{|c|}{ Decision-to-conception interval } \\
\hline$\leq 6$ months & 156 & 65.8 & 150 & 69.4 & \multirow{2}{*}{$p=0.411$} \\
\hline$>6$ months & 81 & 34.2 & 66 & 30.6 & \\
\hline \multicolumn{6}{|l|}{ Mode of fertilization } \\
\hline spontaneous & 230 & 97 & 214 & 99.1 & \multirow{2}{*}{$p=0.180^{* *}$} \\
\hline assisted & 7 & 3 & 2 & 0.9 & \\
\hline \multicolumn{6}{|c|}{ Tobacco habits during pregnancy } \\
\hline non-users & 218 & 92 & 205 & 94.9 & $p=0.211$ \\
\hline \multicolumn{6}{|l|}{$\begin{array}{l}\text { Complications in } \\
\text { obstetric history }^{* * *}\end{array}$} \\
\hline yes & 20 & 8.4 & 34 & 15.7 & \multirow{2}{*}{$p=0.017$} \\
\hline no & 217 & 91.6 & 182 & 84.3 & \\
\hline
\end{tabular}


Parous women were older, had more obstetric complications previously and were more likely to be married than their nulliparous counterparts. Almost one-fourth of parous women had previous CS $(n=51,23.6 \%)$. Table 12 shows mid-pregnancy childbirth preferences and W-DEQ A scores of nulliparous and parous respondents. Altogether nine out of 10 respondents $(n=410,90.5 \%)$ would have chosen VD given the choice. Nulliparous women had higher W-DEQ A scores than their parous counterparts.

Table 12. Mid-pregnancy preference for childbirth and W-DEQ A scores of nulliparous and parous women

\begin{tabular}{|c|c|c|c|c|c|}
\hline & \multicolumn{2}{|c|}{$\begin{array}{c}\text { Nulliparous } \\
n=\mathbf{2 3 7}\end{array}$} & \multicolumn{2}{|c|}{$\begin{array}{l}\text { Parous } \\
n=216\end{array}$} & \multirow[t]{2}{*}{ sig. } \\
\hline & $n /$ mean & $\% / \mathrm{SD}$ & $n /$ mean & $\% / \mathrm{SD}$ & \\
\hline \multicolumn{6}{|l|}{ Childbirth preference } \\
\hline VD & 220 & 92.8 & 190 & 88 & \\
\hline $\mathrm{CS}$ & 12 & 5.1 & 23 & 10.6 & $p=0.075^{*}$ \\
\hline undecided/no response & 5 & 2.1 & 3 & 1.4 & \\
\hline W-DEQ A score & 54.9 & 20.2 & 46.2 & 21.1 & $p<0.001^{* *}$ \\
\hline
\end{tabular}

With regard to obstetric outcome, no deliveries took place beyond $42^{\text {nd }}$ gestational week, but there was preterm delivery in $4.4 \%$ of the cases $(n=20)$. Eight nulliparous women $(1.8 \%)$ had assisted VD, while one-third of respondents $(n=151)$, but significantly more nulliparous $(n=95 ; 40.1 \%)$ than parous $(n=56 ; 25.9 \%)$ women had CS $(p=0.001)$. Of those not delivering vaginally, 15 (9.9\%) went through elective CS, 93 (61.6\%) had intrapartum CS, and $43(28.5 \%)$ had non-elective operation without effectively starting to labor. The rate of VBAC in this sample was 10/51 (albeit two of these women had already gone through VBAC at the end of their previous pregnancies). Almost three-fourth (41/56) of parous women, who delivered by CS this time, had CS previously. Table 13 shows subsequent mode of delivery and how it was related to mid-pregnancy childbirth preference and W-DEQ A score. Significant correlation was detected only in case of parous women: two-thirds of those delivering by CS preferred VD previously, whereas those delivering vaginally had lower WDEQ A scores. 
Table 13. Mode of delivery of nulliparous and parous respondents related to their midpregnancy preference for childbirth and W-DEQ A scores

\begin{tabular}{|c|c|c|c|c|c|}
\hline \multirow[b]{3}{*}{ Nulliparous $(n=237)$} & \multicolumn{2}{|c|}{ VD or assisted VD } & \multicolumn{2}{|c|}{ CS } & \multirow[t]{2}{*}{ sig. } \\
\hline & $n /$ mean & $\% / \mathrm{SD}$ & $n /$ mean & $\% / \mathrm{SD}$ & \\
\hline & \multicolumn{2}{|c|}{$n=142$} & \multicolumn{2}{|c|}{$n=95$} & \\
\hline \multicolumn{6}{|l|}{ Childbirth preference } \\
\hline VD & 134 & 94.4 & 86 & 90.5 & \multirow{2}{*}{$p=0.262^{*}$} \\
\hline CS/undecided/no response & 8 & 5.6 & 9 & 9.5 & \\
\hline W-DEQ A score & 54.3 & 20.1 & 55.7 & 20.5 & $p=0.583^{* *}$ \\
\hline Parous $(n=216)$ & \multicolumn{2}{|c|}{$n=160$} & \multicolumn{2}{|c|}{$n=56$} & \\
\hline \multicolumn{6}{|l|}{ Childbirth preference } \\
\hline VD & 153 & 95.6 & 37 & 66.1 & \multirow{2}{*}{$p<0.001^{*}$} \\
\hline CS/undecided/no response & 7 & 4.4 & 19 & 33.9 & \\
\hline W-DEQ A score & 43.8 & 21.5 & 52.9 & 18.5 & $p=0.005^{* *}$ \\
\hline
\end{tabular}

Supplementary obstetric outcome data regarding the time of delivery and the attending obstetrician are shown in Table 14. No significant difference was detected between nulliparous and parous respondents by bivariate analysis except the day of week of delivery. Most deliveries took place during working hours, and there were almost twice as many deliveries on Friday than on Saturday, with an increasing trend of deliveries towards the last weekday in case of parous women. Only one-third of deliveries were attended by the obstetrician on duty.

Binary logistic regression models explaining delivery outcome with childbirth preference, W-DEQ A score and factors depicted in Tables 11,12 and 14 are shown in Table 15. Three variables contributed independently to the binary logistic regression model of nulliparous respondents aimed to explain delivery by CS. A negative contribution of the principal component 'Being in control' and a positive impact of a longer decision-toconception interval and the attending obstetrician's power to decide upon CS was detected. In the third step the goodness-of-fit was 0.11 . The model for parous respondents showed much higher goodness-of-fit (0.43). The variables that had a significant positive impact were principal components ' $\mathrm{CS}$ is more beneficial than VD' and 'Environmental influence' and the age of the attending obstetrician, while age of the respondent contributed negatively to the model describing delivery by CS. 
Table 14. Supplementary obstetric outcome data regarding time of delivery and the attending obstetrician

\begin{tabular}{|c|c|c|c|c|c|}
\hline & \multicolumn{2}{|c|}{$\begin{array}{c}\text { Nulliparous } \\
n=\mathbf{2 3 7}\end{array}$} & \multicolumn{2}{|c|}{$\begin{array}{l}\text { Parous } \\
n=216\end{array}$} & \multirow[t]{2}{*}{ sig." } \\
\hline & $n$ & $\%$ & $n$ & $\%$ & \\
\hline \multicolumn{6}{|l|}{ Time of day } \\
\hline 7 a.m. to 3 p.m. & 111 & 46.8 & 87 & 40.3 & \multirow{3}{*}{$p=0.155$} \\
\hline 3 p.m. to 11 p.m. & 71 & 30.0 & 62 & 28.7 & \\
\hline 11 p.m. to 7 a.m. & 55 & 23.2 & 67 & 31.0 & \\
\hline \multicolumn{6}{|l|}{ Day of week } \\
\hline Monday & 41 & 17.3 & 21 & 9.7 & \multirow{7}{*}{$p=0.020$} \\
\hline Tuesday & 46 & 19.4 & 28 & 13.0 & \\
\hline Wednesday & 26 & 11.0 & 34 & 15.7 & \\
\hline Thursday & 26 & 11.0 & 40 & 18.5 & \\
\hline Friday & 40 & 16.9 & 44 & 20.4 & \\
\hline Saturday & 27 & 11.4 & 21 & 9.7 & \\
\hline Sunday & 31 & 13.1 & 28 & 13.0 & \\
\hline \multicolumn{6}{|c|}{$\begin{array}{l}\text { Patient's own obstetrician at } \\
\text { delivery }\end{array}$} \\
\hline yes & 160 & 67.5 & 145 & 67.1 & \multirow{2}{*}{$p=0.931$} \\
\hline no & 77 & 32.5 & 71 & 32.9 & \\
\hline \multicolumn{6}{|c|}{$\begin{array}{l}\text { The attending obstetrician's } \\
\text { power to decide upon delivery }\end{array}$} \\
\hline yes & 152 & 64.1 & 132 & 61.1 & \multirow{2}{*}{$p=0.506$} \\
\hline no & 85 & 35.9 & 84 & 38.9 & \\
\hline \multicolumn{6}{|c|}{$\begin{array}{l}\text { Gender of the attending } \\
\text { obstetrician }\end{array}$} \\
\hline male & 148 & 62.4 & 141 & 65.3 & \multirow{2}{*}{$p=0.531$} \\
\hline female & 89 & 37.6 & 75 & 34.7 & \\
\hline \multicolumn{6}{|c|}{ Age of the attending obstetrician } \\
\hline $20 \mathrm{~s}$ & 22 & 9.3 & 30 & 13.9 & \multirow{6}{*}{$p=0.061$} \\
\hline $30 \mathrm{~s}$ & 140 & 59.1 & 108 & 50.0 & \\
\hline $40 \mathrm{~s}$ & 34 & 14.3 & 46 & 21.3 & \\
\hline $50 \mathrm{~s}$ & 16 & 6.8 & 9 & 4.2 & \\
\hline $60 \mathrm{~s}$ & 24 & 10.1 & 19 & 8.8 & \\
\hline $70 \mathrm{~s}$ & 1 & 0.4 & 4 & 1.9 & \\
\hline
\end{tabular}


Table 15. Multiple logistic regression models built up by forward conditional variable selection method explaining mode of delivery

\begin{tabular}{|c|c|c|c|c|c|c|c|c|}
\hline \multicolumn{7}{|c|}{ Nulliparous $(n=237)$} & & \\
\hline Sig. & & 0.000 & & 0.000 & & 0.000 & & \\
\hline Nagelkerke R-squared & & 0.051 & & 0.084 & & 0.110 & & \\
\hline variables & sig. & $\operatorname{Exp}(B)$ & sig. & $\operatorname{Exp}(B)$ & sig. & $\operatorname{Exp}(B)$ & & \\
\hline The obstetrician's power to decide upon CS & 0.003 & 2.295 & 0.004 & 2.229 & 0.008 & 2.125 & & \\
\hline Decision-to-conception interval & & & 0.013 & 2.023 & 0.014 & 2.022 & & \\
\hline Principal component 'Being in control' & & & & & 0.029 & 0.714 & & \\
\hline \multicolumn{9}{|c|}{ Parous $(n=216)$} \\
\hline Sig. & & 0.000 & & 0.000 & & 0.000 & & 0.000 \\
\hline Nagelkerke R-squared & & 0.336 & & 0.382 & & 0.409 & & 0.430 \\
\hline variables & sig. & $\operatorname{Exp}(B)$ & sig. & $\operatorname{Exp}(B)$ & sig. & $\operatorname{Exp}(B)$ & sig. & $\operatorname{Exp}(B)$ \\
\hline Principal component ' $\mathrm{CS}$ is more beneficial than VD' & 0.000 & 3.176 & 0.000 & 3.260 & 0.000 & 3.492 & 0.000 & 2.527 \\
\hline Age of the attending obstetrician & & & 0.003 & 1.576 & 0.001 & 1.694 & 0.004 & 1.598 \\
\hline Age (in years) & & & & & 0.022 & 0.905 & 0.023 & 0.905 \\
\hline Principal component 'Environmental influence' & & & & & & & 0.040 & 1.613 \\
\hline \multicolumn{9}{|c|}{$\begin{array}{l}\text { Logistic regression, forward conditional method. Dependent variable: mode of delivery } 0=\text { VD or assisted VD; } 1=\mathrm{CS} \text {. Independent variables: } \\
\text { Principal component 'Being in control'; Principal component 'Right to autonomy'; Principal component 'In close contact with the newborn'; Principal } \\
\text { component 'Trust in the natural way'; Principal component 'Environmental influence'; Principal component 'CS is more beneficial than VD'; } \\
\text { Principal component 'Expectations toward maternity care'; Principal component 'VD, the object of fear'; W-DEQ A score; level of education (in } \\
\text { years); place of residence; self-rated financial status; tobacco habits; age (in years); civil status; planned pregnancy; decision-to-conception interval; } \\
\text { mode of fertilization; complications in obstetric history; childbirth preference; gestational age; time of day of delivery; day of week of delivery; } \\
\text { patient's own obstetrician attending delivery; obstetrician's power to decide upon CS; gender of the attending obstetrician; age of the attending } \\
\text { obstetrician }\end{array}$} \\
\hline
\end{tabular}




\section{Discussion}

\subsection{Ambivalent attitudes of south-east Hungarian obstetricians}

The ideal Hungarian CS rate would only slightly be lower than what actually was in $2010(33.03 \%, 1)$, according to south-east Hungarian obstetricians, but it would be still two times higher than what was appointed by the World Health Organization consensus conference in 1985 (63). It stated that no additional reduction in perinatal (both maternal and neonatal) morbidity and mortality could be warranted by CS rates exceeding $10-15 \%$. Tolerant attitude of obstetricians toward the proportion of CSs is apparent and certainly has an impact on the societal acceptance of the phenomenon.

Remarkable difference was found between female and male obstetricians with regard to the estimation of Hungarian CDMR rates and women preferring CS vs. VD. Males were more conservative in these ratings, while female obstetricians' ratings suggested that there were more procedures performed without firm medical indication. This finding is possibly due to differences in communication: female obstetricians, usually younger, might be approached by women in a more sensitive and less rational way, which can open the door to a dialogue about feelings or anxiety in relation with perinatal issues. In contrast, male obstetricians, in particular older ones, tend to communicate in a more 'paternalistic' manner, patients unconsciously line up to. Beside the indisputable benefits of the latter communication style, it is also apparent that it does not facilitate an open conversation about irrational emotions, fears or requests (64). Therefore it is possible that they meet fewer women, who express concern about the forthcoming delivery, and this can be an explanation for why they seem to be more convinced about the medical grounding of CSs.

More than half of the respondents turned the option of a legalized CDMR down; however, almost one-third of them would have supported such an option, indicating that south-east Hungarian obstetricians' opinion is not equivocal in this question. The more liberal attitude of physicians from tertiary institutions can be explained by the fact that they work in an environment where CSs are more common, basically due to higher rates of women with non-physiologic pregnancies, thus their sensitivity to higher CS rates is not so explicit, compared with that of their counterparts working in urban hospitals. Another possibility is that in a large town setting they may be receiving significantly more maternal requests, which inevitably makes them come up with possible solutions. However, this assumption needs to 
be confirmed by further investigation that compares birth preferences of women planning to deliver in different levels of hospitals.

Beside fear of long-lasting and painful labor and worry about the well-being of the child, making the best of patient autonomy was one of the most important maternal motivations, according to respondents. On the other hand, the majority of them excluded the possible role of health care personnel - direct or indirect this role may be. The fundamental contribution of patient pressure to rising CS rates is questioned by many studies $(5,19,24,43$, 65). The understatement of the role of health care personnel recalls the words of Savage et al. applied for British consultants: 'We gained the impression that obstetricians felt disempowered and unable to change things in the face of factors outside their control [...]' (65). A similar phenomenon of transferring responsibility has been observed by Weaver et al.: when asking obstetricians about the main reasons for rising cesarean rates in the U.K., the most frequent response was 'maternal request', although the respondents 'reported few requests themselves' (5). They also noted that although all women interviewed in their study, having considered, or having been asked to consider CS during pregnancy 'expressed an overriding concern for the baby to be born safe and well', not even one talked about a 'right to choose caesarean section' (5). The term CDMR implicitly suggests that if a woman wants to deliver this way so eagerly, she can - but with this decision she has to bear all the responsibility for the complications that might occur. This hypothetical interpretation was also confirmed by the EUROBS study group, who found a significant trend 'between obstetricians' self-reported feeling that their clinical practice was influenced, occasionally or often, by fear of litigation and the willingness to perform a caesarean delivery at the patient's request' (3).

In the Netherlands, it was found that the main reason for obstetricians willing to perform CDMR was respect for patient autonomy (66). In our study, however, only onefourth of obstetricians theoretically willing to perform CDMR, agreed the statement regarding respect for patient autonomy, and this was far not the most frequently supported 'pro' CS statement (i.e. statements that might explain the willingness to perform CDMR) by the 'willing to perform CDMR' group of respondents. Moreover, a larger proportion of them agreed the 'pro CS' statements regarding the role of epidemiological changes, lawsuits threatening physicians, easier timing, preserving pelvic floor integrity and the beneficial effect of elective CS on the fetus, compared with the group theoretically rejecting to perform CDMR. These findings clearly suggest that respect for patient autonomy was far not the most important motivation for them. Considering that almost $60 \%$ of all obstetricians chose the 
statement that confronted the paternalistic model with the service provider model of communication, while only seven $(6.9 \%)$ physicians admitted that it was important for their patients to have a voice in their mode of delivery, it is possible that south-east Hungarian obstetricians would not plead patient pressure, a frequently alluded determinant of rising CS rates in other parts of the world (67-69).

Many authors raise the question whether pregnant women's decisions could be found in the background of CDMRs, or rather, physician's paternalism (70), convenience $(2,71)$, financial interests $(20-21,72-73)$ or interventionist attitudes (74). One previous Hungarian and a Colombian study have shown that physician convenience does play a role in the timing of CSs $(2,71)$. It was found in Brazil that despite the lack of significant difference in pregnant women's preferences toward the mode of delivery, women receiving private care had a twice as high risk as those in public care to end up delivering by CS (21). Another Brazilian study, besides emphasizing the role of financial incentives, highlighted the boom of medical schools at the expense of decline of midwifery schools as an important contributor to the trend of rising CS rates (20). South-east Brazilian skyrocketing CS rates were partly attributed to the close relationship between doctors and privately insured patients, since only electively scheduled CS could ensure that the patient's own physician would attend the delivery (72). Even a study from England detected an association between elective CS and patient affluence (73) suggesting that the role of financial incentives is not negligible.

One study about ethics in prenatal diagnostics expressed concern about the interventionist views of people who are most involved in counseling (74). On the other hand, Green and Baston showed that patients' attitudes have also shifted towards greater willingness to accept obstetric interventions since the late 1980s; however, they pose that it may be the 'ethos of women's choice' that allows caregivers to intervene more possibly when facing a patient who shows willingness to accept it, even if they are not convinced that it is clinically necessary (75).

Declerque et al. proposed these procedures to be called 'no indicated risk', pleading to the lack of true documentation regarding any medical risk factors or complications of labor or delivery. They argued that the lack of (true) documentation was not necessarily equal to explicit maternal request (76). However, it is possible that true medical indications supporting an intervention are lacking, still, firm diagnoses are listed in the patient file (such as prolonged labor, acute fetal compromise, feto-pelvic disproportion, malpresentation, etc.). This practice was called ‘socially permitted justification' by Gomes et al. (72). 
The way an obstetrician counsels patients is widely rooted in his/her convictions about obstetrical questions $(59,74)$. Respect for patient autonomy and medical paternalism have traditionally been seen as conflicting terms (64). It is likely that patients with a certain attitude find doctors whose practice fit their expectations: women who insist on delivering by CDMR do not necessarily look for a 'good' doctor, who always has the right answers to the occurring problems, but for the 'proper' one who is willing to perform the operation on them without any question. The contradiction between the theoretical willingness of the majority of obstetricians in this study to perform CDMR and the dismissive opinion of more than half of them on the legalization of it in Hungary, along with their insistence on their professional superiority to be acknowledged by their patients is thought-provoking, though. The resistance of more than half of physicians to an explicit indication for CDMR might have been explained by the traditionally paternalistic doctor-patient relationship that still dominates the obstetric profession. It may also have reflected the official position of the Hungarian College of Obstetrics and Gynecology on CDMR, issued in 2003 (53); however, their practice did not necessarily follow theory. These findings highlighted a segment of the complex reality of $21^{\text {st }}$ century obstetrics, including obstetricians' challenge to make their professional standards and experience consistent with circumstances of financing, and the expectations of their patients and the society.

\subsection{Determinants of childbirth preference and mode of delivery}

This survey aimed to unfold determinants of maternal childbirth preference and nonmedical factors contributing to different modes of delivery in one of the five university obstetric departments in Hungary. We followed-up 411 pregnant women throughout pregnancy in order to unveil important factors in the background of preference for CS or uncertain childbirth preference. We also analyzed 453 non high-risk pregnant women's sociodemographic features, childbirth-related attitudes, fears and preferences and the circumstances among which subsequent deliveries took place and their association with delivery outcome.

\subsubsection{The majority of south-east Hungarian pregnant women prefer VD}

Our second survey of pregnant women is a contribution to the ever growing body of evidence, that, given the chance, only small numbers of pregnant women would choose primary operative delivery in the absence of medical indications $(33,43,77-80)$, since nine out of 10 respondents expressed preference for VD as mode of delivery in mid-pregnancy. 
Vaginal delivery has traditionally been the standard for pregnant women for many millennia - having no other options before the $20^{\text {th }}$ century. In order to address maternal uncertainty and possible changes in preference through time (81), we decided to compose two groups of respondents in both analyses. Those who were either determined in their preference for CS or uncertain in their preference, deviated from the 'norm', which was represented by those who were consistent in their preference for VD (Group 2 in the first analysis) or expressed explicit preference for VD in mid-pregnancy (in the second analysis). This survey, for the first time in Hungary, demonstrated that there were no extremely high numbers of pregnant women with preference for CS, since around $90 \%$ of both samples preferred VD as mode of delivery.

\subsubsection{The association between childbirth preference, delivery outcome and W-DEQ A} scores

In the first analysis of pregnant women bivariate analysis revealed the same association between mean W-DEQ A scores and preference for CS or ambivalent birth preference as a Finnish study did (33); however, neither principal component 'VD, the object of fear', nor W-DEQ A scores contributed to any of our regression models. This means that level of FOC was not an important contributor to childbirth preference in this case.

In the second analysis nulliparous women tended to have higher W-DEQ A scores than their parous counterparts, which is equivocal with the international findings (26-28). However, neither their W-DEQ A score, nor their preference for delivery predicted delivery outcome. Although bivariate analysis revealed a correlation between both preference for childbirth and W-DEQ A score and delivery outcome in case of parous women, neither of these factors entered the logistic regression models, suggesting that women's fears or childbirth preference were not independent predictors of the actual delivery outcome.

There has been an ongoing debate on whether high level of antenatal FOC or antenatal preference for CS can be related to obstetric complications such as emergency CS or ventouse/forceps delivery. Ryding et al. in a Swedish sample of women found that FOC measured in third trimester was associated with emergency CS due to imminent fetal asphyxia (16). The same association was detected by Laursen et al. in a Danish cohort of healthy nulliparous women; however, the link was dystocia or protracted labor, but not fetal distress (17). Antenatal preference for CS, maternal age and previous CS independently predicted elective and emergency CS in an unselected Swedish sample (82). In contrast, Johnson and 
Slade found nulliparity, presence of medical risk factors, previous CS and maternal anticipation of CS, but not antenatal FOC to be predictive of emergency CS in an unselected UK sample (26). Although Fenwick et al. found an association between antenatal FOC and emergency CS in healthy pregnant Australian women, after adjustment for nulliparity and fetal compromise the association disappeared (27). The latter authors suggest that in countries where activity of midwifery and obstetrics bring about a relative equilibrium, the needs and fears of women can materialize in their pure reality. On the other hand, in maternity care models where power inequality among professionals is obvious and private obstetric care complicates the scene, the effect of women's attitudes may be played down by other factors. They also conclude that differently conceptualized childbirth and its effect on maternity care policies might be found in the background of different CS rates of countries, rather than individual maternal factors such as FOC (27). Nonetheless, Sluijs et al. could not reveal any correlation between FOC and delivery outcome in a Dutch cohort of healthy women with low-risk pregnancies (28).

Nevertheless, comparison with other studies investigating the association between level of FOC and subsequent delivery outcome might have been hampered by the fact that questionnaires in most of these studies were completed in the last trimester, while our questionnaires were completed in mid-pregnancy. Moreover, the Hungarian translation of WDEQ A has not yet been validated. Therefore we refrain from any comparisons of average WDEQ A scores with the results of other studies.

4.2.3. The role of socio-demographic factors and maternal attitudes in shaping childbirth preference

The first logistic regression analysis did not reveal any differences between participants' main demographic characteristics according to their childbirth preference, apart from previous CS. More than half of maternal preference for CS or uncertainty regarding preferred mode of delivery (represented by Group 1) could be ascribed to women having undergone previous CS. Furthermore, more than half of women with previous CS, while less than $10 \%$ of nulliparous women and only three parous women without previous CS were in Group 1.

The role of previous CS in the alteration of maternal preference for birth has been highlighted by several studies from different countries $(43,77-78,80,83)$. With regard to maternal motivations, Gamble and Creedy found that women with previous CS, who reported 
being disappointed with their previous delivery experience, were more likely to prefer CS in their subsequent pregnancy, compared with those who were satisfied with the previous delivery (78). Thus, it seems to be likely that preference for CS is not based on satisfaction with the previous experience of CS. Furthermore, it is possible that CS does not provide women with the sense of personal fulfillment, what VD potentially does (84). Therefore, we need to suspect other motivations or attitudes in the background of maternal preference for CS in case of previous CS.

Although investigating the indications of our respondents' previous CSs was out of the scope of this survey, it is known from a retrospective analysis performed in 2006 in our department, that the most remarkable contribution to the rising CS rate in 10 years was due to indications 'prolonged first stage of labor' and 'fetal compromise' (85). Experience of CS performed for prolonged first stage of labor might convince a woman that she is not able to deliver her baby, whereas, the diagnosis of fetal compromise can label VD as 'dangerous'. According to our results, these cognitive interpretations of perinatal events, along with mistrust in the power of nature, strongly determine the birth preference of not just many parous women with previous CS, but also that of a small but not negligible portion of nulliparous women. The difference is that while these strong beliefs of women with previous CS are based on their own previous delivery experience (principal component 'Expectations toward maternity care'), their nulliparous counterparts primarily recline on information gained from relatives, friends, acquaintances or even obstetric professionals (principal component 'Environmental influence'). Munro et al. called the attention to the impact of persuasive social influences on nulliparous women: in spite of the small numbers of women preferring CS, the influence of emotive birth stories (positively tinged CSs and negatively set VDs) on women who miss their own experience is not negligible (86). Fenwick et al. describe this 'vicarious trauma' as a result of a cognitive process (87).

Disclosing the reasons for why certain women prefer CS implicates hints about what prevents others from opting for abdominal delivery. We found two principal attitude components which contributed in a negative way to the multiple regression models: the principal component 'Being in control' for the nulliparous respondents and the principal component 'Trust in the natural way' for the total sample. Nulliparous women consistent in their preference for VD were more likely to be insisting on their own sense of control. This finding is just the opposite of what one of the interviewees of a qualitative study said about her experience of elective CS: 'although I wasn't in control myself, I knew that there were 
people around me to look after me' (84). This sentence depicts how personal control can be shifted to medical personnel in case of CS, which is an act possibly less problematic for nulliparous women in favor of CS, according to our results.

The above mentioned results call the attention to the appropriate and sufficient amount of information given to pregnant and postpartum women. Gamble and Creedy questioned the well-informed preferences of women in their study who opted for elective CS (78). They showed that only few of them were aware of any risks of the procedure for either themselves or for the baby. On the contrary, almost all of them were able to mention any perceived or suspected advantages of the operation (78). Chen and Hancock showed that many women who underwent cesarean section lacked the sufficient amount of information about their delivery options in subsequent pregnancies. The authors emphasized that not being aware of the recent scientific evidence of drawbacks and benefits of either trial of labor or repeat cesarean prevented these women from rethinking their preference (88).

Green and Baston found an increased antenatal anxiety about pain during labor and a reduced belief in the ability to cope with labor, parallel with an increased willingness to accept obstetric interventions, which was interpreted as a possible consequence of increased use of birth technology (75). In our survey, women consistent in their preference for VD were more likely to be convinced that birth is not necessarily about medical technology. Nevertheless, Hungarian CS rates seem to be high enough to gradually erode women's basic belief in the power of nature and to make them develop a certain tolerance toward CS, by depicting it as 'safe and simple'.

\subsubsection{Maternal attitudes, childbirth preferences, socio-demographic characteristics} and supplementary obstetric outcome data contributing to mode of delivery

Although higher W-DEQ A scores and mid-pregnancy maternal childbirth preference did not contribute to the logistic regression models explaining obstetric outcome in our sample of women, some maternal attitudes did enter the models. While principal component 'Environmental influence' referred to an extrinsic pressure on parous women not to be involved in VD, principal component ' $\mathrm{CS}$ is more beneficial than VD' certified an intrinsic belief that CS was the more advantageous and less dangerous of the two options. On the other hand, higher score reached by nulliparous women at principal component 'Being in control' seemed to be 'protective' against CS. The complementary phenomenon was described by Haines et al.: Australian and Swedish women in the 'Take it as it comes' group were not 
afraid of delivery, but had no firm preference of birth, therefore were more likely to accept obstetric interventions when those were phrased around the well-being of the child (89).

In our survey, one of the most important objective predictors of subsequent delivery by CS detected in mid-pregnancy was decision-to-conception interval longer than six months in case of nulliparous respondents. Growing decision-to-conception interval can enhance the 'precious baby' concept of both women and obstetricians. Kingdon et al. claim that the concept of maternal choice regarding mode of birth is challenged by many different factors: personal preference is not that important in view of safety concerns (24). Obstetricians, on the other hand, are likely to approach 'precious' pregnancies in a defensive way in order to avoid malpractice litigation. Walker et al., who investigated thresholds of patients and their caregivers toward fetal risk, found that both groups of respondents had low tolerance for fetal risk associated with VD (90). Women in medicalized model of care were less tolerant compared with those involved in lower intervention model; as the authors put it 'these women may have lowered their expectations for vaginal birth' (90). It seems that health care provider type does play a role in the perception of benefits or risks of different types of delivery, thus different groups of women are exposed to different kind of information with emphasis put on different facts $(46,91-92)$. Alternatively, from the aspect of attitudes toward birth technology, different, self-selecting populations of pregnant women resort different forms of maternity care (92). Either way it develops, the phenomenon of over-estimation of risks in pregnancy seems to drive both women and obstetricians to engage in even more risky procedures (93).

The possible role of convenience and financial incentives of obstetricians emerged especially in countries with high CS rates. Potter et al. found that the huge difference between CS rates of private and public obstetric patients in Brazil could not be explained by the difference in their preference of delivery, since it was not significant. They offered three explanations instead: private doctors were truly convinced that CS was more beneficial for patients; they were not receptive enough to find out what their patients really wanted, and simply assumed it was elective CS. The third possible explanation was that scheduled CSs provided better time management than unpredictable VDs for busy obstetricians (22). Entirely different aspect of private practice was highlighted by Abenhaim et al., who found that Canadian on-call obstetricians compared with the patients' own doctors were more likely to rush to the operating theatre in case of suspected fetal compromise. The explanation for the finding given by the authors was the protective role of good doctor-patient relationship against malpractice lawsuits (94). Gyarmati et al. investigated whether timing of deliveries or 
the age of the attending obstetrician contribute to the CS rates in one of the hospitals in Budapest, capital of Hungary. They found that CSs were more frequent on workdays and before major holidays, in June and December, but the other, personal factor did not contribute to the rising CS rates (2). All above mentioned phenomena are good examples of non-medical factors influencing medical willingness to intervene.

In contrast with these findings, neither private practice, nor timing contributed significantly to the model describing mode of subsequent delivery in multivariate analysis. Two factors related to the attending obstetricians, however, played an important role, namely their power to decide upon CS in case of nulliparous and their age in case of parous women. It is not likely that Hungarian obstetricians are not susceptive of the patients' preferences, given the continuous personal care provided throughout pregnancy in the majority of the cases. Although having the power to decide upon CS can provide better time management for a professional, it also means that he/she bears all responsibility in an obstetric situation to deliver the 'perfect outcome', which might lead to defensive acts. Older age and more experience of the attending obstetrician can also lead to certain cautiousness in doubtful cases.

In case of parous women one surprising factor needs to be highlighted that prevented them from delivering by CS: older age. Older maternal age has been a traditional argument for rising CS rates (82), but in this survey we detected the opposite role of it. It seems that the biological effect of ageing on the body of women was balanced by other, most probably cultural factors.

The majority of women in this study consistently preferred VD antenatally; however, one-third of them delivered by CS. 'The number of women preferring or requesting a CS is far fewer than the number of women receiving the procedure', referred Gamble et al. to the conclusion of their previous review of the literature of CS on maternal request, doubting that the available research establishes women's requests' true role in high CS rates (19). Potter et al. found that there were large numbers of Brazilian private patients who underwent unwanted CS (21). Seven years later they showed that the proportion of certain medical indications (e.g. malpresentations) reported by private patients who underwent CS was higher than that in the public sector. They highlighted that liberal attitude toward CS 'could reduce rather than increase the chances women have to achieve their preferred type of delivery' (22).

Since around one-third of respondents delivered by CS, which is the same CS rate as the national one, the authors assume that these results are generalizable to the entire pregnant 
population in the country. In order to minimize the effect of medical factors, we excluded women known to be high-risk already at mid-pregnancy, and those who were well-informed about anticipating CS for medical reasons (with the exception of women with previous CS). The relative weakness of the logistic regression model explaining delivery outcome of nulliparous women suggested that other factors not investigated in this study (most likely medical ones) have a comparably larger contribution to the subsequent delivery outcome in their case. On the other hand, the relative strength of the model for parous women highlighted that in their case medical factors can easily become overshadowed by other aspects. 


\section{Conclusions}

Most south-east Hungarian obstetricians agreed that there was no need in Hungary for a legalized indication that would allow obstetricians to perform CS without firm medical reasons, but almost one-third of them would have welcomed such an option. However, the majority of the respondents felt ready to perform such an operation in case it was a legal option. Respect for patient autonomy was not a central issue for most of the respondents; therefore, we suspect other factors in the background of the finding that more than threequarters of them would be ready to perform CDMR in case it was legalized.

The majority of respondents in the survey of pregnant women consistently preferred to give birth vaginally. Higher level of fear of childbirth was not identified among the important predisposing factors of an ambivalent or dismissive attitude toward vaginal delivery by multivariate analysis. Certain attitudes, however, did differentiate between pregnant women with distinct preferences for childbirth. Previous CS was also found to be an important contributor to preference for CS or uncertain preference, which was equivocal to the findings of several studies in this field. Although we detected small numbers of women with explicit and consistent preference for CS throughout pregnancy, the possible normalizing effect of high Hungarian CS rate on nulliparous women's cognitive appraisal regarding childbirth issues needs to be considered.

Although nine out of 10 non high-risk pregnant women preferred VD to CS in midpregnancy, one-third of the women ended up having CS. Multivariate analysis did not prove women's mid-pregnancy level of fear of childbirth or preferences to be contributing to delivery outcome; instead, younger maternal age and longer decision-to-conception interval turned out to be important determinants of CS. Among supplementary delivery outcome data timing of delivery did not, while factors related to the attending obstetrician, did contribute to mode of delivery. These findings further contribute to the already existing evidence that in countries with high CS rates the role of non-medical factors, more positively related to obstetricians than to pregnant women's preferences or fears, need to be emphasized. A shift from the present Hungarian maternity care model toward a balance between medical and midwifery approach could provide women with the entire spectrum of information on maternity issues, which would improve patient autonomy and possibly lower the domestic CS rate. 


\section{References}

1. Tauffer Database. National Institute for Quality- and Organizational Development in Healthcare and Medicine (http://193.225.50.35/webgy/regbe/belepes.php), cited July 11, 2014.

2. Gyarmati B, Nagy P, Tiba J. Trends in prevalence of caesarean section in Uzsoki Hospital between $1^{\text {st }}$ January, 1999 and $30^{\text {th }}$ June, 2009. Analysis of some suspected factors. (A császármetszések gyakoriságának változása és néhány feltételezett ok elemzése az Uzsoki utcai kórházban 1999. január 1. és 2009. június 30. között.) Magy Nőorv L. 2009;72:269-272.

3. Habiba M, Kaminski M, Da Fré M, Marsal K, Bleker O, Librero J, Grandjean H, Gratia P, Guaschino S, Heyl W, Taylor D, Cuttini M. Caesarean section on request: a comparison of obstetricians' attitudes in eight European countries. BJOG. 2006;113:647-656.

4. Coleman VH, Lawrence H, Schulkin J. Rising cesarean delivery rates. The impact of cesarean delivery on maternal request. Obstet Gynecol Surv. 2009;64:115-119.

5. Weaver JJ, Statham H, Richards M. Are there „unnecessary” cesarean sections? Perceptions of women and obstetricians about cesarean sections for nonclinical indications. Birth. 2007;34:37-41.

6. Feldman GB, Freiman JA. Prophylactic cesarean at term? N Eng J Med. 1985;312: 1264-1267.

7. Wax JR, Cartin A, Pinette MG, Blackstone J. Patient choice cesarean: an evidencebased review. Obstet Gynecol. 2004;59:601-616.

8. Druzin ML, El-Sayed YY. Cesarean delivery on maternal request. Wise use of finite resources? A view from the trenches. Semin Perinatol. 2006;30,305-308.

9. Ecker JL. Once a pregnancy, always a cesarean? Rationale and feasibility of a randomized controlled trial. Am J Obstet Gynecol. 2004;190,314-318.

10. Bergeron V. The ethics of cesarean section on maternal request: A feminist critique of the American College of Obstetricians and Gynecologists' position on patient-choice surgery. Bioethics. 2007;21:478-487.

11. Nilstun T, Habiba M, Lingman G, Saracci R, Da Frè M, Cuttini M, EUROBS study group. Cesarean delivery on maternal request: Can the ethical problem be solved by the principlist approach? BMC Med Ethics. 2008;9:11. 
12. Minkoff H, Powderly KR, Chervenak F, McCullough LB. Ethical dimensions of elective primary cesarean delivery. Obstet Gynecol. 2004;103:387-392.

13. Keeton K, Zikmund-Fisher BJ, Ubel PA, Fenner DE, Fagerlin A. The accuracy of predicting parity as a prerequisite for cesarean delivery on maternal request. Obstet Gynecol. 2008;112:285-289.

14. NIH State-of-the-Science Conference Statement on Cesarean Delivery on Maternal Request. NIH Consens Sci. Statements. 2006;23:1-29.

15. Kalish RB, McCullogh L, Gupta M, Thaler HT, Chervenak FA. Intrapartum elective cesarean delivery: A previously unrecognized clinical entity. Obstet Gynecol. 2004;103:1137-1141.

16. Ryding EL, Wijma B, Wijma K, Rydhström H. Fear of childbirth during pregnancy may increase the risk of emergency cesarean section. Acta Obstet Gynecol Scand. 1998;77:542-547.

17. Laursen M, Johansen C, Hedegaard M. Fear of childbirth and risk for birth complications in nulliparous women in the Danish National Birth Cohort. BJOG. 2009; 116:1350-1355.

18. Haines HM, Rubertsson C, Pallant JF, Hildingsson I. Women's attitudes and beliefs of childbirth and association with birth preference: A comparison of a Swedish and an Australian sample in mid-pregnancy. Midwifery. 2012;28:e850-856.

19. Gamble J, Creedy DK, McCourt C, Weaver J, Beake S. A critique of the literature on women's request for cesarean section. Birth. 2007;34:331-340.

20. Rebelo F, Da Rocha CMM, Cortes TR, Dutra CL, Kac G. High cesarean prevalence in a national population-based study in Brazil: the role of private practice. Acta Obstet Gynecol Scand. 2010;89:903-908.

21. Potter JE, Berquó E, Perpétuo IH, Leal OF, Hopkins K, Souza MR, Formiga MC. Unwanted caesarean sections among public and private patients in Brazil: prospective study. BMJ. 2001;323:1155-1158.

22. Potter JE, Hopkins K, Faúndes A, Perpétuo I. Women's autonomy and scheduled cesarean sections in Brazil: a cautionary tale. Birth. 2008;35:33-40.

23. Leeman LM, Plante LA. Patient-choice vaginal delivery? Ann Fam Med. 2006;4:265268.

24. Kingdon C, Neilson J, Singleton V, Gyte G, Hart A, Gabbay M, Lavender T. Choice and birth method: mixed-method study of caesarean delivery for maternal request. BJOG. 2009;116:886-895. 
25. Gibbons L, Belizán JM, Lauer JA, Betrán AP, Merialdi M, Althabe F. The global numbers and costs of additionally needed and unnecessary caesarean sections performed per year: Overuse as a barrier to universal coverage. World Health Report (2010) Background paper No. 30

26. Johnson R, Slade P. Does fear of childbirth during pregnancy predict emergency caesarean section? BJOG. 2002;109:1213-1221.

27. Fenwick J, Gamble J, Nathan E, Bayes S, Hauck Y. Pre- and postpartum levels of childbirth fear and the relationship to birth outcomes in a cohort of Australian women. J Clin Nurs. 2009;18:667-677.

28. Sluijs AM, Cleiren MP, Scherjon SA, Wijma K. No relationship between fear of childbirth and pregnancy-/delivery-outcome in a low-risk Dutch pregnancy cohort delivering at home or in hospital. J Psychosom Obstet Gynecol. 2012;33:99-105.

29. Waldenström U, Hildingsson I, Ryding EL. Antenatal fear of childbirth and its association with subsequent caesarean section and experience of childbirth. BJOG. 2006;113:638-646.

30. Nieminen K, Stephansson O, Ryding EL. Women's fear of childbirth and preference for cesarean section - a cross-sectional study at various stages of pregnancy in Sweden. Acta Obstet Gynecol Scand. 2009;88:807-813.

31. Nilsson C, Lundgren I, Karlström A, Hildingsson I. Self reported fear of childbirth and its association with women's birth experience and mode of delivery: a longitudinal population-based study. Women Birth. 2012;25:114-121.

32. Wijma K, Wijma B, Zar M. Psychometric aspects of the W-DEQ; a new questionnaire for the measurement of fear of childbirth. J Psychosom Obstet Gynaecol. 1998;19:8497.

33. Rouhe H, Salmela-Aro K, Halmesmäki E, Saisto T. Fear of childbirth according to parity, gestational age, and obstetric history. BJOG. 2009;116:67-73.

34. Korukcu O, Kukulu K, Firat MZ. The reliability and validity of the Turkish version of the Wijma Delivery Expectancy/Experience Questionnaire (W-DEQ) with pregnant women. J Psychiatr Ment Health Nurs. 2012;19:193-202.

35. Takegata M, Haruna M, Matsuzaki M, Shiraishi M, Murayama R, Okano T, Severinsson E. Translation and validation of the Japanese version of the Wijma Delivery Expectancy/Experience Questionnaire version A. Nurs Health Sci. 2013;15:326-32. 
36. Saisto T, Halmesmäki E. Fear of childbirth: a neglected dilemma. Acta Obstet Gynecol Scand. 2003;82:201-208.

37. Wijma K. Why focus on 'fear of childbirth'? J Psychosom Obstet Gynaecol. 2003;24:141-143.

38. Zar M, Wijma K, Wijma B. Pre- and postpartum fear of childbirth in nulliparous and parous women. Scand J Behav Ther. 2001;30:75-84.

39. Alehagen S, Wijma B, Wijma K. Fear of childbirth before, during, and after childbirth. Acta Obstet Gynecol Scand. 2006;85:56-62.

40. Söderquist J, Wijma B, Thorbert G, Wijma K. Risk factors in pregnancy for posttraumatic stress and depression after childbirth. BJOG. 2009;116:672-680.

41. Christiaens W, Bracke P. Assessment of social psychological determinants of satisfaction with childbirth in a cross-national perspective. BMC Pregnancy Childbirth. 2007;7:26.

42. Hemminki E, Klemetti R, Gissler M. Cesarean section rates among health professionals in Finland, 1990-2006. Acta Obstet Gynecol Scand. 2009;88:1138-1144.

43. Karlström A, Nystedt A, Johansson M, Hildingsson I. Behind the myth - few women prefer caesarean section in the absence of medical or obstetrical factors. Midwifery. 2011;27:620-627.

44. Stjernholm YV, Petersson K, Eneroth E. Changed indications for cesarean sections. Acta Obstet Gynecol Scand. 2010;89:49-53.

45. Karlström A, Nystedt A, Hildingsson I. A comparative study of the experience of childbirth between women who preferred and had a caesarean section and women who preferred and had a vaginal birth. Sex Reprod Healthc. 2011;2:93-99.

46. Reime B, Klein MC, Kelly A, Duxbury N, Saxell L, Liston R, Prompers FJ, Entjes RS, Wong V. Do maternity care provider groups have different attitudes towards birth? BJOG. 2004;111:1388-1393.

47. Menacker F, Declercq E, MacDorman MF. Cesarean delivery: background, trends, and epidemiology. Semin Perinatol. 2006;30:235-241.

48. Ford J, Grewal J, Mikolajczyk R, Meikle S, Zhang J. Primary cesarean delivery among parous women in the United States, 1990-2003. Obstet Gynecol. 2008;112:1235-1241.

49. Papp Z. A szülészet-nőgyógyászat tankönyve. Budapest: Medicina, 2009. 
50. Gaal P, Belli PC, McKee M, Szócska M. Informal payments for health care: definitions, distinctions, and dilemmas. J Health Polit Policy Law. 2006;31:251-93.

51. Gaal P, Evetovits T, McKee M. Informal payment for health care: evidence from Hungary. Health Policy. 2006;77:86-102.

52. Baji P, Gulácsi L. Situation unchanged. Results of a representative questionnaire survey on Hungarian people's habits and attitudes toward informal payments. (A helyzet változatlan. Egy reprezentatív kérdöíves felmérés eredményei a magyar lakosság hálapénz-fizetési szokásairól és a hálapénz megítéléséről.) Egészségügyi Gazdasági Szemle. 2012;50:30-36.

53. The official position of the Hungarian College of Obstetrics and Gynecology regarding the proportion of caesarean sections and the prevention of further rise in caesarean section rate. (A Szülészeti és Nőgyógyászati Szakmai Kollégium 2003. február 28-i állásfoglalása a császármetszések arányának alakulásával és a további emelkedés kívánatos megelőzésével kapcsolatban.) Magy Nőorv L. 2003;66:191-192.

54. Ugocsai Gy. When performing a cesarean section is permissible? (Mikor szabad császármetszést végezni?) Nőgyógyászati és Szülészeti Továbbképző Szemle. 2003;1:8-16.

55. Berkő P. Absolute and relative indications and co-indications for caesarean sections. (Gondolatok a császármetszés javallatairól és a frekvencia csökkentésének lehetőségéröl.) Magy Nőorv L. 2007;70:269-280.

56. McCourt C, Weaver J, Statham H, Beake S, Gamble J, Creedy DK. Elective cesarean section and decision-making: A critical review of the literature. Birth. 2007;34:65-71.

57. Szeverényi P, Póka R, Hetey M, Török Z. Contents of childbirth-related fear among couples wishing the partner's presence at delivery. J Psychosom Obstet Gynecol. 1998;19:38-43.

58. Karlström A, Engström-Olofsson R, Nystedt A, Thomas J, Hildingsson I. Swedish caregivers' attitudes towards caesarean section on maternal request. Women Birth. 2009;22:57-63.

59. Johanson R, Burr R, Leighton N, Jones $\mathrm{P}$. Informed choice? Evidence of the persuasive power of professionals. J Pub Health Med. 2000;22:439-440.

60. Dweik D, Mészáros Gy. Cesarean section on maternal request? Survey among southeast Hungarian midwives. (Császármetszés anyai kérésre? Mi a dél-kelet magyarországi szülésznők véleménye?) Bábák, szülésznők. 2011;10:9-13. 
61. Dweik D, Szimjanovszki I, Mészáros G, Pál A. Cesarean delivery on maternal request: Survey among obstetricians/gynecologists in south-east Hungary. (Császármetszés anyai kérésre - ahogyan a délkelet-magyarországi szülész-nőgyógyászok látják.) Orv Hetil. 2013,33:1303-11.

62. Field A. Discovering Statistics Using SPSS. London: SAGE Publications, 2005.

63. World Health Organisation. Appropriate technology for birth. Lancet. 1985;2:436437.

64. Emanuel EJ, Emanuel LL. Four models of the physician-patient relationship. JAMA. 1992;267:2221-2226.

65. Savage W, Francome C. British consultants' attitudes to caesareans. J Obstet Gynaecol. 2007;27:354-359.

66. Kwee A, Cohlen BJ, Kanhai HHH, Bruinse HW, Visser GH. Caesarean section on request: a survey in the Netherlands. Eur J Obstet Gynaecol Repr Biol. 2004;113:186190.

67. Mould TA, Chong S, Spencer JA, Gallivan S. Women's involvement with the decision preceding their caesarean section and their degree of satisfaction. BJOG. 1996;103:1074-1077.

68. Robson SJ, Tan WS, Adeyemi A, Dear KB. Estimating the rate of cesarean section by maternal request: anonymous survey of obstetricians in Australia. Birth. 2009;36:208212.

69. Cotzias CS, Paterson-Brown S, Fisk NM. Obstetricians say yes to maternal request for elective caesarean section: a survey of current opinion. Eur J Obstet Gynecol Repr Biol. 2001;97,15-16.

70. Graham WJ, Hundley W, McCheyne AL, Hall MH, Gurney E, Milne J. An investigation of women's involvement in the decision to deliver by caesarean section. BJOG. 1999;106:213-220.

71. Gómez OL, Carrasquilla G. Factors associated with unjustified Cesarean section in four hospitals in Cali, Colombia. Int J Qual Health Care. 1999;11:385-389.

72. Gomes UA, Silva AAM, Bettiol H, Barbieri MA. Risk factors for the increasing caesarean section rate in Southeast Brazil. A comparison of two birth cohorts, 19781979 and 1994. Int J Epidemiol. 1999;28:687-694.

73. Alves B, Sheikh A. Investigating the relationship between affluence and elective caesarean sections. BJOG. 2005;11:994-996. 
74. Al-Mufti R, McCarthy A, Fisk NM. Survey of obstetricians' personal preference and discretionary practice. Eur J Obstet Gynaecol Repr Biol. 1997;73:1-4.

75. Green JM, Baston HA. Have women become more willing to accept obstetric interventions and does this relate to mode of birth? Data from a prospective study. Birth. 2007;34:6-13.

76. Declercq E, Menacker F, MacDorman M. Rise in "no indicated risk" primary caesareans in the United States, 1991-2001: cross sectional analysis. BMJ. 2005;330,71-72.

77. Mazzoni A, Althabe F, Liu NH, Bonotti AM, Gibbons L, Sánchez AJ, Belizán JM. Women's preference for caesarean section: a systematic review and meta-analysis of observational studies. BJOG. 2011;118:391-399.

78. Gamble JA, Creedy DK. Women's preference for a cesarean section: incidence and associated factors. Birth. 2001;28:101-110.

79. Ecker JL. Elective cesarean delivery on maternal request. JAMA. 2013;309:19301936.

80. Torloni MR, Betrán AP, Montilla P, Scolaro E, Seuc A, Mazzoni A, Althabe F, Merzagora F, Donzelli GP, Merialdi M. Do Italian women prefer cesarean section? Results from a survey on mode of delivery preferences. BMC Pregnancy Childbirth. $2013 ; 13: 78$

81. Kingdon C, Baker L, Lavender T. Systematic review of nulliparous women's views of planned cesarean birth: the missing component in the debate about a term cephalic trial. Birth. 2006;33:229-237.

82. Hildingsson I. How much influence do women in Sweden have on caesarean section? A follow-up study of women's preferences in early pregnancy. Midwifery. 2008;24:46-54.

83. Kudish B, Mehta S, Kruger M, Russell E, Sokol RJ. Delivery route preferences of urban women of low socioeconomic status. Int J Gynaecol Obstet. 2010;111:28-31.

84. Fenwick J, Staff L, Gamble J, Creedy DK, Bayes S. Why do women request caesarean section in a normal, healthy first pregnancy? Midwifery. 2010;26:394-400.

85. Szabó D, Kozinszky Z, Orvos H, Németh G, Pál A. Changes in attitude in the decision making regarding Caesarean sections at our department. (Szemléletváltás a császármetszések indikációjában klinikánkon.) Magy Nőorv L. 2006;69:11-16. 
86. Munro S, Kornelsen J, Hutton E. Decision making in patient-initiated elective cesarean delivery: the influence of birth stories. J Midwifery Womens Health. 2009;54:373-379.

87. Fenwick J, Gamble J, Hauck Y. Reframing birth: a consequence of caesarean section for a self-selected group of Western Australian women. J Adv Nurs. 2006;56:121-132.

88. Chen MM, Hancock H. Women's knowledge of options for birth after Caesarean Section. Women Birth. 2012;25:e19-e26.

89. Haines HM, Rubertsson C, Pallant JF, Hildingsson I. The influence of women's fear, attitudes and beliefs on mode and experience of birth. BMC Pregnancy Childbirth. 2012;12:55.

90. Walker SP, McCarthy EA, Ugoni A, Lee A, Lim S, Permezel M. Cesarean delivery or vaginal birth. A survey of patient and clinician thresholds. Obstet Gynecol. 2007;109:67-72.

91. Monari F, di Mario S, Fachinetti F, Basevi V. Obstetricians' and midwives' attitudes toward cesarean section. Birth. 2008;35:129-135.

92. Klein MC, Kaczorowski J, Hearps SJ, Tomkinson J, Baradaran N, Hall WA, McNiven P, Brant R, Grant J, Dore S, Brasset-Latulippe A, Fraser WD. Birth technology and maternal roles in birth: knowledge and attitudes of Canadian women approaching childbirth for the first time. J Obstet Gynaecol Can. 2011;33:598-608.

93. Robinson M, Pennell CE, Mclean NJ, Oddy WH, Newnham JP. The over-estimation of risk in pregnancy. J Psychosom Obstet Gynecol. 2011; 32:53-58.

94. Abenhaim HA, Benjamin A, Koby RD, Kinch RA, Kramer MS. Comparison of obstetric outcomes between on-call and patients' own obstetricians. CMAJ. 2007; 177:352-373. 


\section{Acknowledgments}

I would like to hereby express my honest thanks to Professors György Bártfai and Attila Pál, without whom it was not possible to launch my scientific work: they provided me the time, the space and the financial background to execute my surveys.

I owe hearty thanks to my supervisor, Gyula Mészáros, whose unbelievable tolerance and exhaustless patience helped me in following my incuriosity.

I would like to express my sincere gratitude to my statistician, Edmond Girasek, who brought life into my data. Without his invaluable work, my publications would still be manuscripts in a drawer.

I am particularly grateful to my respondents: colleagues and women, for not only restlessly completing my questionnaires, but also, many times, even getting them lively with personal confessions. These encounters really made my day. I am very grateful to all those clinical workers who tolerated my presence while collecting data.

I also owe thanks to all domestic and foreign professionals (doctors, midwives, nurses, antenatal nurses, etc.) I met during my life for all the though-provoking conversations that set me in my way.

Every day of my life I will need to thank my husband, Sándor Tordai for his patience and brilliance, and my loving children, Tegze, Zenke, Maja, Léna for their teachings. I owe thanks to my parents, Salaheddin Dweik and Katalin Seres, for the stamina and the protagonism in me. 


\section{Brief summary in Hungarian (A Doktori Értekezés magyar nyelvű összefoglalása)}

A dél-kelet magyarországi császármetszések hátterében álló nem orvosi tényezők

\section{Bevezetés és célkitűzés}

A világ sok más országához hasonlóan a magyarországi császármetszések aránya is meredeken emelkedik a nyolcvanas évek vége óta: míg 1989-ben csupán 11\% volt, addig 2012-ben 34,5\%-ra nőtt ez az arány. A látványos növekedés hátterében az anyai kérésre végzett császármetszések szerepe is felmerült, annak ellenére, hogy hazánkban nincs olyan hivatalos indikáció, amely alapján egy ilyen beavatkozás legálisan elvégezhető lenne. Anyai kérésre végzett császármetszésről beszélünk, ha fiziológiás, egyszeres terhességet követően, terminusban elektív császármetszés történik, megalapozott orvosi indikáció nélkül, csupán a terhes asszony kérése alapján. A jelenségnek már a puszta létezése is heves viták tárgyát képezte az utóbbi közel két évtizedben, és a mai napig nemzetközi publikációk sokasága foglalkozik a kérdéssel, melynek interdiszciplináris jelentőségét mutatja, hogy a szük értelemben vett orvos-szakmai korlátokat szétfeszítve közgazdász, egészségpolitikus, pszichológus, szociológus, sőt orvosi etikával, orvosi kommunikációval foglalkozó szakemberek a fent említett publikációk jelentős hányadának szerzői.

A jelenség nem hivatalos jellege miatt az anyai kérésre végzett császármetszések számának pontos meghatározása lehetetlen, bármilyen kutatás célja legfeljebb a nagyságrendre vonatkozó hozzávetőleges becslés lehet. A jelen disszertáció alapjául szolgáló kutatások célkitüzése a két, hazánkban leginkább érintett populáció - a szülész-nőgyógyászok és a várandós nők - a kérdéshez kapcsolódó véleményének, hozzáállásának feltérképezése volt. A szülész-nőgyógyászok véleménye azért jelentős, mert amennyiben valóban tömeges jelenséggé vált az anyai császármetszés preferencia, úgy azt minden bizonnyal ők érik leghamarabb tetten. Másfelől, mivel a jelenség megvalósulásához önmagában az anyai kérés nem elég, hanem fontos eleme a beavatkozást elvégző szakember is, fontosnak tartottuk a szülész-nőgyógyászok esetleges, a kérdéssel kapcsolatos megengedő attitüdjének feltárását is. A várandós asszonyok körében végzett kutatás elsősorban az anyai szülési preferenciát vizsgálta, különös tekintettel a császármetszésre irányuló illetve bizonytalan preferenciával bírók motivációira. Ezen kutatás másik fő kérdése az volt, hogy a terhesek által a második 
trimeszter közepén megfogalmazott szülési preferenciát, illetve erőteljesebb szüléstől való félelmet milyen mértékben tükrözi a majdani szülés módja.

\section{Anyag és módszer}

A kutatásokat kérdőíves módszerrel végeztük. A Bács-Kiskun, Békés, Csongrád megyei szülészeti intézményekben dolgozó szülészorvosok (102/137) 2010 márciusában töltötték ki a strukturált, anonim kérdőíveket, melyek főbb kérdései a következők voltak: az ideális magyarországi császármetszés-frekvencia, az anyai kérésre végzett császármetszések aránya az összes császármetszésen belül, a császármetszést preferáló egészséges várandósok aránya, a terhesek hüvelyi szüléstől való elzárkózásának hátterében álló lehetséges motivációk. További kérdések voltak a következők: szükség lenne-e hazánkban a jelenség liberálisabb szabályozására, és amennyiben legális lenne az anyai kérésre végzett császármetszés, válaszadóink ajánlanák- illetve elvégeznék-e. Az adatelemzéshez használt statisztikai módszerek a következők voltak: chi² -próba, független mintás T-próba, MannWhitney-féle U teszt, Fisher-féle egzakt teszt.

A 2011 és 2012 fordulóján a Szegedi Tudományegyetem Szülészeti és Nőgyógyászati Klinikáján rutin ultrahang vizsgálaton megforduló, a részvételi kritériumoknak megfelelő, szegedi és Szeged környékén élő várandósok (487/516) egy peripartum követéses vizsgálatban vettek részt. A részvétel feltételei a következők voltak: nagykorúság/cselekvőképesség, a magyar nyelv ismerete, alacsony- vagy közepes kockázatú, egyszeres terhesség viselése, és hogy ne legyen a hüvelyi szülést kizáró ismert ok. Ezen kutatás antepartum időszakban kitöltött kérdőívei illetve a szülésre vonatkozó, kórlapokból és személyes találkozás során nyert adatok szolgáltatták a disszertáció második felének adatait. A kérdőívek főbb kérdései a szülési preferenciára, a szüléssel kapcsolatos attitűdökre, és a válaszadók fóbb szocio-demográfiai adataira vonatkoztak, továbbá a várandósok mindkét vizsgált trimeszterben kitöltötték a Wijma Delivery Expectancy/Experience A (W-DEQ A) kérdőív magyarra fordított változatát, amely a szüléstől való félelem erősségét mérte.

A várandósok első vizsgálatában 413 páros - a terhesség közepén és végén kitöltött kérdőív adatait dolgoztuk fel abból a célból, hogy megállapítsuk, hogy milyen arányban van jelen a terhesség folyamán a hüvelyi szüléstől, mint alapértelmezett szülési módtól eltérő anyai preferencia, illetve, hogy miben különböznek a következetesen hüvelyi úton szülni kívánó terhesek azoktól, akik legalább az egyik kérdőívben császármetszésre irányuló preferenciát vagy bizonytalanság jelét mutatták. A második vizsgálatban a második 
trimeszterben kitöltött kérdőívekből származó adatokat (szülési preferencia, W-DEQ A pontszám, attitüdváltozókból képzett főkomponensek és szocio-demográfiai adatok) és a szülés körülményeit (személyi és időzítés) vetettük össze a szülés módjával $(n=453)$. Ez utóbbi adatok forrásául a kórlapok és a megszültekkel való személyes találkozás szolgáltak. A várandósok vizsgálataiban az adatelemzéshez használt statisztikai módszerek a következők voltak: chi ${ }^{2}$-próba, Fisher-féle egzakt teszt, független mintás T-próba, ANOVA-módszer, főkomponens analízis, 59elt5959ve logisztikus regresszió analízis.

\section{Eredmények}

A szülész-nőgyógyászok körében végzett felmérésben a válaszadók szerint a terminusban lévő, egyszeres, fiziológiás terhességet viselő várandósok több mint negyede szívesebben szülne császármetszéssel, mint hüvelyi úton. Legfontosabb motivációként az elhúzódó és fájdalmas szüléstől és a születendő gyermek egészségének károsodásától való anyai félelmet jelölték meg. A szülészorvosok több mint fele $(55,9 \%)$ elutasította annak elméleti lehetőségét, hogy hazánkban legálissá váljon a megalapozott orvosi indikáció hiányában, pusztán az anya kérésére végzett császármetszés intézménye, 30,4\%-uk szerint azonban szükség lenne olyan indikációra, amely ezt a beavatkozást legálissá tenné. Mindazonáltal, ha a törvényi szabályozás erre lehetőséget teremtene, $81(79,4 \%)$ szülészorvos kész lenne elvégezni a beavatkozást, közülük 12-en (11,8\%) fel is ajánlanák pácienseiknek ezt a lehetőséget.

A várandósok szülési preferenciáit vizsgáló kutatásban a válaszadók $88,4 \%$-a $(n=$ 365) következetesen (a vizsgálat mindkét időpontjában) a hüvelyi szülés mellett tette le a voksát. A terhesség közepén 28 (6,5\%), végén 31 (7,5\%) fö jelzett császármetszésre irányuló preferenciát. A császármetszést legalább az egyik időpontban preferálók és a bizonytalanok döntésének hátterében az előzetes császármetszést, a hüvelyi szüléssel kapcsolatos 59elt5959ve, valamint a császármetszéssel kapcsolatos pozitív anyai vélekedéseket, és a természetes folyamatokba vetett bizalom hiányát sikerült kimutatni logisztikus regressziós módszerrel. Egyéb szocio-demográfiai jellemzők, attitüd-főkomponensek illetve a szüléstől való félelem mértéke nem járultak hozzá jelentős mértékben a hüvelyi szüléssel szembeni anyai averzióhoz.

A második, várandósokkal kapcsolatos vizsgálatban tízből kilenc középidős terhes hüvelyi úton szeretett volna szülni, ezzel szemben a szülés az esetek egy-harmadában császármetszéssel történt; az először szülők 40,1\%-a, az előzetes császármetszésen átesettek 
négy-ötöde (41/51) szült ilyen módon. Többváltozós módszert alkalmazva sem a magasabb pontszám a szüléstől való félelmet mérő skálán, sem az anyai szülési preferencia nem bizonyult meghatározó tényezőnek a szülési kimenetel tekintetében. Ezzel szemben az elhatározástól a megfoganásig eltelt hosszabb idő, fiatalabb anyai, idősebb szülészorvosi életkor, a szülésnél jelen lévő orvos császármetszés-indikációs jogköre és bizonyos anyai attitüdök (lemondás az események feletti kontrollról, a császármetszés biztonságosságába vetett hit, a környezet felöl érkező, az anyát a császármetszés irányába terelő hatások erőssége) jelentettek kockázatot a császármetszéssel való szülés szempontjából.

\section{Megbeszélés}

A szülész-nőgyógyászok több mint felének anyai kérésre végzett császármetszéssel kapcsolatos elutasító véleményének hátterében a paternalisztikus orvos-beteg kapcsolat hagyományait, valamint a Szülészeti és Nőgyógyászati Szakmai Kollégium e kérdésben tett 2003-as állásfoglalásának hatását lehet sejteni. Ezen elzárkózás ugyanakkor ellentétben áll az ilyen beavatkozások elvégzésére irányuló feltételes hajlandósággal, amelyet a válaszadók négy-ötöde mutat.

A disszertáció alapjául szolgáló két kérdőíves vizsgálat eredményeit összevetve úgy tünik, a szülészorvosok túlbecsülték a császármetszéssel szívesebben szülő várandósok arányát, és a hüvelyi szüléstől elzárkózók legfontosabb motivációja sem a hosszú és fájdalmas vajúdás elkerülése illetve az önrendelkezéshez való jog megélése. A Szeged környéki terhesek körében végzett kutatásból kiderült, hogy a nem magas kockázatú, egyszeres terhességet viselő várandósok túlnyomó többsége következetesen hüvelyi úton szeretne szülni. Az ettől eltérő preferenciával 60elt terhesek több, mint fele előzetes császármetszésen esett át, kisebb hányada először szülő volt. Választásuk hátterében - az előzetes császármetszés tényén túl - a természetes folyamatokban megrendült bizalom állt, valamint az a meggyőződés, hogy a császármetszés a hüvelyi szülésnél egészségesebb, veszélytelenebb. A várandósok, és különösen a császármetszésen átesett és a még nem szült nők bizonyítékokon alapuló információkkal való ellátottsága elsősorban a szülészeti szakemberek felelőssége. A magas császármetszés-ráta anyai attitűd-formáló szerepe valószínüsíthető.

A terhesek körében végzett kutatás második fele rávilágított arra, hogy amíg a terhesség közepén kilencből tíz asszony hüvelyi szülést választott volna, ha arra lehetősége adódik, addig a válaszadók egy-harmada végül császármetszéssel hozta világra gyermekét. A 
mütétes szülés hátterében meghúzódó nem orvosi tényezőként az elhatározástól a megfoganásig eltelt hosszabb időt, a szülésnél jelen levő orvos császármetszés-indikációs jogkörét, illetve a személyes kontroll csökkent jelentőségét sikerült azonosítani először szülők esetében. Többedszer szülők esetében ezek a tényezők a várandós attitüdjét a hüvelyi szüléstől elterelő környezeti hatások, az az anyai meggyőződés, hogy a császármetszés a hüvelyi szülésnél egészségesebb, veszélytelenebb, az idősebb orvosi, és a fiatalabb anyai életkor voltak. Az először szülők esetében sem elhanyagolható, de elsősorban a multiparák esetében jelentős mértékü a nem orvosi faktorok szerepe a szülés módjának alakulásában. A terhesség közepén megfogalmazott anyai császármetszés-preferencia azonban nem független prediktora szülésnek. 
Appendix 


\section{Appendix 1 (Hungarian version)}

I. Ön szerint mi lenne ma Magyarországon az ideális császármetszés-frekvencia?

$$
\ldots \ldots . . \%
$$

II. Mit gondol, ma Magyarországon a terhességük 37. hetét betöltött, egyszeres terhességet viselő primiparák körülbelül hány százaléka gondolja azt, hogy ha lenne választása, szívesebben szülne elektíven - anyai ill. magzati indikáció híján - elvégzett császármetszés útján, mint hüvelyen keresztül?

........\%

III. Mit gondol, egy ilyen választás hátterében milyen - tudatos vagy tudattalan - anyai motivációk állhatnak?

Kérem, karikázza be ahhoz az indokláshoz tartozó betüjelet, amely Ön szerint lényeges szerepet játszhat abban, hogy egy egyszeres terhességet viselő, terminusban lévő primipara szívesebben szülne császármetszéssel, mint hüvelyen keresztül! Több választ is megjelölhet.

a. Félelem a szülési fájdalomtól.

b. Félelem a szüléshez társuló kontrollvesztéstöl.

c. Félelem a hosszas vajúdástól.

d. Félelem a kiszolgáltatottságtól.

e. Nem bízik a saját testében.

f. Attól fél, hogy nem képes megszülni a gyermekét.

g. Negatív tapasztalatok az egészségügyi ellátással kapcsolatban.

h. Bizalmatlanság az egészségügyi személyzettel szemben.

i. Egyoldalú/nem kielégítő az információkkal való ellátottsága.

j. Terhelő a szülészeti vagy családi anamnézise.

k. Anyai szempontból biztonságosabbnak gondolja a császármetszést, mint a hüvelyi szülést.

1. Gyermeke szempontjából biztonságosabbnak gondolja a császármetszést, mint a hüvelyi szülést.

m. Medencefenéki izmainak integritásának, ezáltal funkciójának (kontinencia, vita sex) károsodásától, elveszítésétől fél.

n. Nehezen türi a bizonytalanságot, feltétlen kontrollt szeretne gyakorolni az események felett.

o. Kényelmesebb és tervezhetőbb így számára a szülés időpontja. 
p. Az orvosával való konzultációk során megbizonyosodott arról, hogy számára a császármetszéssel való szülés felel meg a leginkább

q. Úgy gondolja, joga van a saját teste felett rendelkezni: a kellő információk birtokában jogában áll eldönteni, milyen módon szeretne szülni.

r. „Trendy” dolog császármetszéssel szülni.

s. Egyéb (ha praxisában tapasztalt a fentieken túli motivációt, kérem írja le!):

IV. Ön szerint ma Magyarországon az összes császármetszésnek valójában hány százalékát tehetik ki az anyai vagy magzati érdek megléte híján, pusztán anyai kérésre elvégzett beavatkozások?

.......\%

V. Ön szerint a magyarországi szülészeti gyakorlatban szükség lenne-e olyan császármetszés indikációra, mely ezt az entitást hivatalos szintre emelné: pl. „császármetszés anyai kérés alapján"?
a. Igen
b. Nem
c. Nem tudom eldönteni.

VI. Ön, mint gyakorló szülész-nőgyógyász ajánlaná-e várandósának ill. vállalná-e ilyen beavatkozás elvégzését, amennyiben a törvényi szabályozás erre lehetőséget biztosítana?
a. Igen, ajánlanám.
b. Nem ajánlanám, de vállalnám.
c. Nem ajánlanám, és nem is vállalnám.
d. Nem tudom eldönteni.

VII. Kérem, gondolja végig, mi minden áll az előző kérdésre adott válasza hátterében! Alaposan olvassa végig az alábbi állításokat, és karikázza be az azon állításokhoz tartozó betüjelet, amelyekkel alapvetően egyetért! Több állítást is megjelölhet!

a. A hüvelyi szüléssel összehasonlítva anyai szempontból biztonságosabbnak gondolom az elektív császármetszést.

b. A hüvelyi szüléssel összehasonlítva magzati szempontból biztonságosabbnak gondolom az elektív császármetszést.

c. A hüvelyi szülést anyai szempontból biztonságosabbnak gondolom az elektív császármetszésnél. 
d. A hüvelyi szülést magzati szempontból biztonságosabbnak tartom, mint egy elektív császármetszést.

e. A mai technikai fejlettségi szint mellett szinte ugyanolyan biztonsági fokon lehet világra segíteni egy magzatot császármetszéssel, mint hüvelyen keresztül.

f. A császármetszések növekvő száma miatt hiányzik az orvosok és szülésznők megfelelő gyakorlata a hüvelyi szülésvezetésben, így relatíve egyre biztonságosabb lesz a császármetszéssel való szülés.

g. A későbbi terhességek, szülések során súlyos komplikációkat okozhat egy megelőző császármetszés.

h. A magzati tüdőéréshez szükségesek a megindult vajúdás során létrejövő hormonális változások.

i. A szoptatás zökkenőmentesebb hüvelyi szülést követően.

j. Gyorsabb a felépülés hüvelyi szülés után, így az édesanya hamarabb tudja gyermekére koncentrálni energiáit.

k. A medencefenéki izmok integritásának, ezáltal funkciójának (kontinencia, vita sex) megőrzése szempontjából előnyösebbnek tartom az elektív császármetszést.

1. Hosszú távon ill. több szülést követően a császármetszés nem garantálja a medencefenéki izmok integritásának megőrzését, viszont hasznosak a medencefenéki izomzat karbantartását célzó gyakorlatok, melyeket már a szülés elött és rögtön a szülés után meg lehet kezdeni.

m. Kényelmesebb és tervezhetőbb a szülés időpontja, ha elektív császármetszést végzünk.

n. Szerintem a terhesnek joga van a saját teste felett rendelkezni: a kellő információk birtokában jogában áll eldönteni, milyen módon szeretne szülni.

o. Ebben a kérdésben is ragaszkodom ahhoz a döntési szabadsághoz, mellyel a szakmám gyakorlása ruház fel.

p. Elvárom a betegeimtől, hogy megbízzanak szakmai tudásomban, ítélőképességemben, és ne csak egy szolgáltatót/technikust lássanak bennem.

q. A pacientúrám megsínylené, ha a várandósaimnak nem lehetne beleszólása a szülésüket érintö kérdésekbe.

r. A jelenleg a manuális szakmákat, de különösen a szülészet-nőgyógyászatot övező perfenyegetettség közepette orvosi egzisztenciámat potenciálisan kevésbé veszélyezteti egy elektíven elvégzett császármetszés, mint egy hüvelyi szülés levezetése.

s. Az elektíven elvégzett császármetszés sem jelent garanciát a perek elkerülésére.

t. A gyermek lelki fejlődésének lényeges állomása a hüvelyi születés megélése.

u. A szülést követő depresszív állapotok gyakoribbak császármetszésen átesett nők körében. 
v. A terhesség nem betegség, a hüvelyi szülés pedig a dolgok természetes módja.

w. A várandósok között egyre nagyobb arányban vannak először szülők, a primiparák átlagéletkora egyre magasabb, egyre gyakoribb az asszisztált reprodukciós technikák igénybevételével fogant terhesség, az újszülöttek egyre nagyobb átlagos súllyal jönnek a világra - mindezek miatt ma már nem olyan magától értetődő folyománya egy terhességnek a hüvelyi szülés.

x. Félnék, hogy ha anyai kérésre, orvosi indikáció híján végeznék császármetszést, azzal hozzájárulnék a szakmám képviselőiröl kialakított negatív közvélekedéshez.

y. Nincs időm a császármetszés összes lehetséges szövődményéről teljes körü felvilágosítást adni, ami a feltétele lenne egy ilyen beavatkozás elvégzésének.

z. Személyes felelösségemnek érzem, hogy a nemzetgazdaság forrásaival takarékosan bánjak: a hüvelyi szülés mindent összevetve olcsóbb a császármetszésnél.

aa. Egyéb (ha felmerül Önben bármi más indok - pro vagy kontra - kérem, írja le!):

\section{Kérem, adja meg az alábbi, demográfiai jellegü adatokat!}

1. Neme:
a. férfi
b. nő

2. A szülész-nőgyógyász szakmában eltöltött éveinek száma:
a. 0-5 év
b. 6-15 év
c. $16-25$ év
d. 26-35 év
e. 36 vagy annál több év

3. Szakmai profilja:
a. Elsősorban szülészet
b. Elsősorban nőgyógyászat, de foglalkozom terhesgondozással is.
c. Elsősorban nőgyógyászat, terhesgondozással nem foglalkozom.
d. Szülészeti és nőgyógyászati tevékenységet nagyjából egyenlő mértékben folytatok.

4. Munkahelyének besorolása:
a. Városi kórház
b. Súlyponti intézmény

5. Van-e jogosultsága császármetszést indikálni?
a. Igen, van.
b. Nem, nincs. 


\section{Appendix 1 (English version)}

I. In your opinion, what would be the optimal CS rate in Hungary? ........\%

II. In your opinion, what is the percentage of Hungarian primiparous women (singleton pregnancy, $\geq 37^{\text {th }}$ gestational week, no maternal or fetal complications) who would prefer elective cesarean section to vaginal delivery, if they had the choice?<smiles>C1CCCCC1</smiles>

III. In your opinion, what kind of maternal motivations (conscious or unconscious) lie in the background of such maternal choice?

Please choose the sentences that, in your opinion, contribute significantly to a nulliparous woman's preference for CS vs. vaginal delivery. Feel free to choose more than one sentence.

a. Fear of labor pain.

b. Fear of losing control during the labor process.

c. Fear of long-lasting labor.

d. Fear of being at the mercy of other people.

e. Does not trust her own body.

f. Fear of not being able to deliver her baby.

g. Previous negative experience regarding health care.

h. Mistrust in health care personnel.

i. Has biased or not adequate information on labor process.

j. Complications in obstetric and/or family history.

k. Finds CS safer than vaginal delivery for the mother's health.

1. Finds CS safer than vaginal delivery for the child's health.

$\mathrm{m}$. Fear of damage to or losing pelvic muscle integrity, leading to incontinence or disturbed sexual life.

n. Has difficulty tolerating uncertainty, prefers keeping events under absolute control.

o. Timing of delivery is easier with CS.

p. Consultations with private obstetrician convinced her that CS is the most adequate mode of delivery for her.

q. Thinks she has the right to decide about her body, e.g. to decide about the way of delivery in possession of adequate information.

r. Finds CS a trendy mode of delivery.

If you can cite any other maternal motivations in the background of preference for abdominal delivery, not mentioned above, please write it here:

IV. In your opinion, what percentage of all CSs in Hungary is performed merely due to maternal request, without any firm maternal or fetal indications?

$\%$ 
V. Do you think it would be necessary to establish an explicit indication for performing CDMR in Hungary (e.g. 'CS on maternal request')?'
a. Yes
b. No
c. Cannot decide

VI. Would you be ready to perform and/or suggest CDMR to patients in case the legislation was more permissive in this field?'

a. Yes, I would suggest it.

b. I would not suggest it, but would be ready to perform it.

c. No, I would neither suggest nor perform it.

d. I cannot decide.

VII. Please, give explanations to your answer! Carefully read through the following statements, and choose the ones you basically agree with. Feel free to choose more than one sentence.

a. I believe elective cesarean is safer than vaginal delivery for the mother.

b. I believe elective cesarean is safer than vaginal delivery for the fetus.

c. I believe vaginal delivery is safer than elective cesarean for the mother.

d. I believe vaginal delivery is safer than elective cesarean for the fetus.

e. Due to the latest technical development, elective cesarean has become almost as safe as vaginal delivery.

f. Due to the rising number of cesareans, physicians and midwives have been lacking adequate skills in vaginal delivery, thus, cesarean delivery has become relatively safer.

g. CS might lead to severe complications in the course of subsequent pregnancies and deliveries.

h. Hormonal changes during labor are important for the maturation of fetal lungs.

i. Breast feeding is less complicated after vaginal delivery.

j. Recovery is faster after vaginal delivery, thus, it is easier for the mother to concentrate totally on the newborn.

k. I believe CS is more favorable for preserving the integrity and function (i.e. continence, sexual life) of the pelvic floor muscles.

1. In the long run and in parous women even CS cannot guarantee to preserve the integrity of the pelvic floor muscles; on the other hand, exercises aiming to keep pelvic floor muscles fit (launched before and right after delivery) are beneficial.

m. Timing of delivery is easier with CS.

n. I believe a pregnant woman has the right to decide about her body, e.g. to decide upon the mode of delivery - in possession of the information needed.

o. I insist on my freedom of judgment that my profession endowed me with.

p. I expect my patients to trust my professional skills and judgment and not to regard me merely as a technician or a supplier.

q. The number of my patients would reduce if pregnant women did not have a voice in their mode of delivery.

r. The current trend of lawsuits threatening physicians working in surgical fields, especially obstetricians, leads to the fact that electively performed CS potentially bears smaller threat on my professional existence compared with vaginal delivery.

s. Electively performed CS does not guarantee to escape lawsuits.

t. Being born vaginally is an important step in the psychic development of a child.

u. Episodes of depression are more likely to develop in those who underwent CS.

v. Pregnancy is not an illness, and vaginal delivery is the natural way of giving birth. 
w. Due to the recent epidemiological changes vaginal delivery at the end of a pregnancy is not self-evident any more.

$x$. If I performed CDMR without medical indication I would be afraid to be contributing to the negative public opinion towards the representatives of my profession.

y. I do not have enough time to provide patients with extensive information about all the potential complications of CS, and that would be an elemental requirement of performing CDMR.

z. I believe it is my personal responsibility to economize on the sources of national economy: all in all vaginal delivery is cheaper than CS.

If you have any other explanations, not mentioned above, please write them here:

Please answer the following questions!

1. Years in practice
a. $0-5$
b. $6-15$
c. $16-25$
d. 26-35
e. more than 36

2. Type of department
a. tertiary
b. urban hospital

3. Main professional field
a. obstetrics and gynecology
b. gynecology
c. obstetrics

4. Authorized to decide upon CS
a. yes
b. no

5. Gender
a. male
b. female 


\section{Appendix 2 (Hungarian version)}

1. A terhessége feléhez közeledve már bizonyára elgondolkodott azon, hogy az Ön számára milyen lehet az ideális szülés. Ha szabadon megválaszthatná, milyen módon szeretne szülni?

a. Spontán, hüvelyi úton.

b. Császármetszéssel.

2. Kérem, egy mondatban indokolja fenti választását!

3. Kérem, alaposan olvassa el az alábbi, szüléssel kapcsolatos állításokat, és jelölje be 6 fokozatú skálán, hogy milyen mértékben ért egyet velük! (A skálán a 0 pont azt jelenti, hogy egyáltalán nem ért egyet az állítással, míg az 5 azt jelzi, hogy teljes mértékben egyetért azzal.)

a. Úgy érzem, minden rendben 70elt a szüléskor.
0
1
2
3
45

Egyáltalán nem.

Teljes mértékben.

b. Félek, hogy nem fogom tudni elviselni a szülési fájdalmat.
o
1
2
3

Egyáltalán nem.
4
Teljes mértékben.

c. Félek, hogy nem fogok tudni uralkodni magamon.
o
1
2
3
4

Teljes mértékben.

Egyáltalán nem.

d. Félek, hogy nagyon kimerítő 70elt a szülés.
o
2
3

Egyáltalán nem.

45

Teljes mértékben.

e. Félek a kiszolgáltatottság érzésétől.
o 1
2
3

\section{5}

Egyáltalán nem.

Teljes mértékben.

f. Félek, hogy nem leszek képes megszülni a gyermekemet.
o
1
2
3
45

Egyáltalán nem.

Teljes mértékben.

g. Szeretném megélni, milyen érzés, amikor megszületik a kisbabám.
$\mathbf{0}$
2
3
45

Egyáltalán nem.

Teljes mértékben.

h. Sok 70elt7070ve tapasztalatom van az egészségügyi ellátással kapcsolatban.
Egyáltalán nem.
$\begin{array}{lll}1 & 2 & 3\end{array}$
$\begin{array}{cc}4 & 5 \\ \text { Teljes mértékben. }\end{array}$

(1.

i. Biztos vagyok abban, hogy a legjobb kezekben leszek.
0
1
2
34

Egyáltalán nem.

j. Úgy érzem, szinte semmit sem tudok arról, hogy mi fog velem történni a szülés napján.
0
1
2
$\begin{array}{lll}3 & 4 & 5\end{array}$

Egyáltalán nem értek egyet.

Teljes mértékben egyetértek.

Teljes mértékben. 
k. A családban, az ismerőseimtől sok borzasztó szüléstörténetet hallottam.
0 1
2
$\begin{array}{lc}\mathbf{4} & \mathbf{5} \\ \text { Teljes mértékben. }\end{array}$

Egyáltalán nem.

1. Nagyon várom már azt a pillanatot, amikor szülést követően magamhoz ölelhetem a kisbabámat.
o
1
2
3
45

Egyáltalán nem.

Teljes mértékben.

m. Félek az altatástól.
$\begin{array}{ll}0 & 1\end{array}$
2
3
45

Egyáltalán nem.

Teljes mértékben.

n. Gyermekem szempontjából biztonságosabbnak gondolom a császármetszést, mint a hüvelyi szülést.
o 1
2
3
34

Egyáltalán nem.

o. Félek, hogy a szexuális életem tönkremegy hüvelyi szülés után.
0
1
2
3
45

Egyáltalán nem.

Teljes mértékben.

p. Félek, hogy a szülés után gondot jelent majd a vizelet tartása.

$\begin{array}{cccccc}0 & 1 & 2 & 3 & 4 & 5 \\ \text { Egyáltalán nem. } & & & & & \text { Teljes mértékben. }\end{array}$

q. Szerintem összességében 71el egy gyermeknek, ha hüvelyi úton születik meg.
o 1
2
Teljes mértékben.

Egyáltalán nem.

r. Rosszul türöm a bizonytalanságot.
o
1
2
3

Egyáltalán nem.

Teljes mértékben.

s. Hiszek abban, hogy a testem tudja a dolgát.
o
2

Egyáltalán nem.

45

Teljes mértékben.

t. Nekem nem mindegy, hogy melyik napon születik meg a gyermekem.
o
1
2
45

Egyáltalán nem értek egyet.

u. Az orvosommal való konzultációk során megbizonyosodtam arról, hogy számomra a császármetszéssel való szülés felel meg leginkább.
0
12
45

Egyáltalán nem.

Teljes mértékben.

v. Úgy gondolom, jogom van a saját testem felett rendelkezni, és eldönteni, hogy hogyan akarok szülni.
0 1
2
3
5

Egyáltalán nem.

w. A császármetszés a szülés sima és egyszerű útja.
1
Teljes mértékben. 
Egyáltalán nem.

Teljes mértékben.

x. Gyermekem egészséges lelki fejlődése szempontjából nagyon fontosnak tartom a hüvelyi születés megélését.
0
1
2
3
45

Egyáltalán nem.

Teljes mértékben.

y. Nagyon szeretnék szoptatni.
0
1
2
3
45

Egyáltalán nem.

Teljes mértékben.

z. Ismerőseim, barátaim a császármetszést javasolják.
0 1
23
45

Egyáltalán nem.

Teljes mértékben.

aa. Minél természetesebb szülést szeretnék.
o 1
2
3
45
Teljes mértékben.

Egyáltalán nem.

bb. Nekem nagyon fontos, hogy minél hamarabb el tudjam látni a babámat.
$\mathbf{0}$
1
2
3
4
5

Egyáltalán nem.

Teljes mértékben.

cc. Maximálisan megbízom az orvosok ítélőképességében.
$\mathbf{0}$
1
2
3
45

Egyáltalán nem.

Teljes mértékben.

dd. Nem bízhatom a véletlenre, hogy egészséges 72elt-e a babám.
01
2
34
45

Egyáltalán nem értek egyet.

Teljes mértékben egyetértek.

ee. Nem lehet valakit akarata ellenére hüvelyi szülésre kényszeríteni.
o
1
2
3
4
5

Egyáltalán nem értek egyet. Teljes mértékben egyetértek.

ff. Sok mindent szeretnék megbeszélni az orvosommal, de úgy érzem, nincs rám elég ideje.
$0 \quad 1$
12
45

Egyáltalán nem értek egyet.

Teljes mértékben egyetértek.

gg. Nagyon rosszul érezném 72elt72, ha császármetszéssel kellene világra hozni a babámat.

$\begin{array}{cccccc}0 & 1 & 2 & 3 & 4 & 5 \\ \text { Egyáltalán nem. } & & & & & \\ \text { Teljes mértékben. }\end{array}$

hh. A párom/ a családom nagyon 72elt engem és a babát a hüvelyi szüléstől.
o
1
2
3
4
5

Egyáltalán nem.

Teljes mértékben. 


\section{Appendix 2 (English version)}

1. As you are heading toward the middle/end of your gestational period, you must have thought about your optimal way of giving birth. Which way would you prefer to deliver your baby, if the decision was up to you?
a. vaginal delivery

b. cesarean section

2. Please, give a brief explanation!

3. Please, carefully read through the following statements and mark the degree of your agreement on a six-point scale after each item! (Zero means you totally disagree, and five means you totally agree with a certain sentence.)

a. I feel that everything will be alright with delivery.
$0 \quad 1$
2
3
4
5

I totally disagree.

I absolutely agree.

b. I am worried that I will not be able to cope with labor pain.
0
1
2
3
4
5

I totally disagree.

I absolutely agree.

c. I am worried that I will not be in control during labor and delivery.
$0 \quad 1$
2
3
4
5

I totally disagree.

I absolutely agree.

d. I am worried that labor and delivery will be very exhausting.
0
1
2
3
4
5

I totally disagree.

I absolutely agree.

e. I fear that I will be defenseless during labor and delivery.

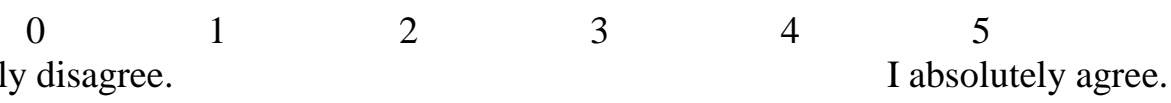

f. I am worried that I will not be able to deliver my baby.
0
1
2
3
4
5
I absolutely agree.

I totally disagree.

g. I would like to experience the moment when my baby is born. 


$\begin{array}{lllllc}0 & 1 & 2 & 3 & 4 & 5 \\ \text { Ially disagree. } & & & & & \\ \text { I absolutely agree. }\end{array}$

h. I have had many bad experiences about health care.

$\begin{array}{lllllc}0 & 1 & 2 & 3 & 4 & 5 \\ \text { disagree. } & & & & & \text { I absolutely agree. }\end{array}$

I totally disagree.

i. I am sure that I will receive the best care during labor and delivery.

$\begin{array}{llllll}0 & 1 & 2 & 3 & 4 & 5\end{array}$

I totally disagree. I absolutely agree.

j. I feel that I know almost nothing about what will happen to me on the day of my delivery.

$\begin{array}{llllll}0 & 1 & 2 & 3 & 4 & 5\end{array}$

I totally disagree. $\quad$ I absolutely agree.

k. I have heard many terrible birth stories of family members and friends.

$\begin{array}{cccccc}0 & 1 & 2 & 3 & 4 & 5 \\ \text { I totally disagree. } & & & & & \text { I absolutely agree. }\end{array}$

1. I am looking forward to holding my baby in my arms right after delivery.

$\begin{array}{llllll}0 & 1 & 2 & 3 & 4 & 5\end{array}$

I totally disagree. $\quad$ I absolutely agree.

$\mathrm{m}$. The concept of general anesthesia frightens me.

$\begin{array}{llllll}0 & 1 & 2 & 3 & 4 & 5\end{array}$

I totally disagree.

n. I believe that CS is the safer way for my baby to be delivered.

0

12

I totally disagree.

2

3

34

45

I absolutely agree.

o. I am worried about my sexual life being spoilt after VD.
$0 \quad 1$
2
3
4
5
I absolutely agree.

p. I am worried that urinary incontinence will develop after VD.

$\begin{array}{cccccc}0 & 1 & 2 & 3 & 4 & 5 \\ \text { I totally disagree. } & & & & & \text { I absolutely agree. }\end{array}$

q. In my opinion, it is better for a child to be born vaginally.
0
1
2
3
4
5
I absolutely agree.

I totally disagree. 
r. It is hard for me to cope with uncertainty.

$\begin{array}{lllllc}0 & 1 & 2 & 3 & 4 & 5 \\ y \text { disagree. } & & & & & \text { I absolutely agree. }\end{array}$

s. I trust my body's implicit knowledge.
0 1
2
3
4
5

I totally disagree.

I absolutely agree.

t. It does matter to me which day my baby will be born on.
$0 \quad 1$
2
3
4
5

I totally disagree.

I absolutely agree.

u. My doctor convinced me that CS is the most adequate way for me to deliver my baby.
$0 \quad 1$
2
3
4
5

I totally disagree.

I absolutely agree.

v. I believe that I have the right to make decisions regarding my body and to choose the way I want to deliver my baby.
0 1
2
3
4
5

I totally disagree.

I absolutely agree.

w. CS is a simple and easy way of delivery.
0
1
2
3
4
5

I totally disagree.

I absolutely agree.

$\mathrm{x}$. I believe that being born vaginally is very important for the healthy psychological development of my baby.
I totally disagree.
2
3
4
5
I absolutely agree.

y. I would like to breastfeed.

0

12

3

4

5

I totally disagree.

I absolutely agree.

z. Acquaintances and friends of mine recommend CS.
0
1
2
3
4
5
I absolutely agree.

I totally disagree.

aa. I would like to have a delivery as natural as possible.

$0 \quad 1$

2

3

4

5

I totally disagree.

I absolutely agree.

bb. It is very important for me to be able to take care of my baby as soon as possible after delivery. 


$\begin{array}{lllllc}0 & 1 & 2 & 3 & 4 & 5 \\ \text { lly disagree. } & & & & & \\ \text { I absolutely agree. }\end{array}$

cc. I absolutely trust the judgment of obstetricians.

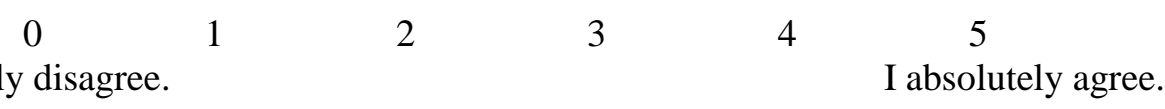

dd. You cannot force a woman to be delivering vaginally.

$\begin{array}{llllll}0 & 1 & 2 & 3 & 4 & 5\end{array}$

I totally disagree. $\quad$ I absolutely agree.

ee. I would like to discuss many issues with the doctor but I feel that he is always short of time.

$\begin{array}{lllllc}0 & 1 & 2 & 3 & 4 & 5 \\ \text { y disagree. } & & & & & \text { I absolutely agree. }\end{array}$

ff. I would be very disappointed if I had to deliver by CS.

$\begin{array}{cccccc}0 & 1 & 2 & 3 & 4 & 5 \\ \text { I totally disagree. } & & & & & \text { I absolutely agree. }\end{array}$

gg. My partner/my family members are worried about what could happen to me and my baby during VD.

$0 \quad 1$

I totally disagree.
2

3

4

I absolutely agree 
Appendix 3 (Hungarian version)

Kérdőív a szüléshez kapcsolódó várakozások és élmények feltérképezésére

(W-DEQ) A változat

\section{ÚTMUTATÓ}

(C) 2005 K. Wijma

Ezen kérdőív célja, hogy feltárja a majdani vajúdáshoz és szüléshez kapcsolódó érzéseket és gondolatokat.

A kérdésekre adott válaszok egy 0-tól 5-ig terjedő skálán találhatók. A skála két végén elhelyezkedő válaszok (0 és 5) egy bizonyos érzés vagy gondolat ellenkező végleteinek felelnek meg.

Kérem, minden kérdésnél karikázza be azt a számot, amelyik a leginkább megfelel annak, ahogyan az Ön előtt álló vajúdást illetve szülést elképzeli.

Kérem, válaszai azt tükrözzék, ahogyan elképzeli majdani vajúdását és szülését - és ne azt, ahogyan reméli, hogy zajlani fog.

I Mit gondol, hogyan fog alakulni a vajúdás illetve a szülés összességében?

1

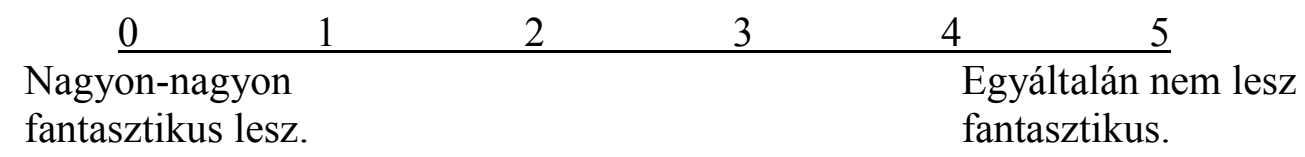

2

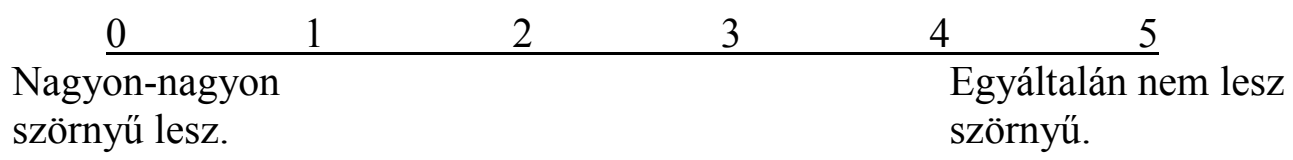

II Mit gondol, hogyan fogja érezni magát a vajúdás illetve a szülés alatt általánosságban?

$$
\underline{0}
$$

Teljesen magányosnak fogom magam érezni.
23

$4 \quad 5$

Egyáltalán nem fogom magányosnak érezni magam.

4

$$
\underline{0}
$$

2
$2 \quad 3$ Rendkívül erősnek fogom magam érezni.

Egyáltalán nem fogom erősnek érezni magam.

5

Teljesen eltölt majd a magabiztosság érzése.

6

$\stackrel{0}{0} \quad 1$
Tele leszek
aggodalommal.

2 3

\begin{tabular}{ll}
$3 \quad 5$ & \multicolumn{1}{c}{5} \\
& Egy csepp \\
magabiztosság \\
sem lesz bennem.
\end{tabular}

7

0

$1 \quad 2$

$2 \quad 3$

4

Teljesen védtelennek

fogom magam érezni.

Egyáltalán nem fogom védtelennek érezni magam. 
II Mit gondol, hogyan fogja érezni magát a vajúdás illetve a szülés alatt?

8

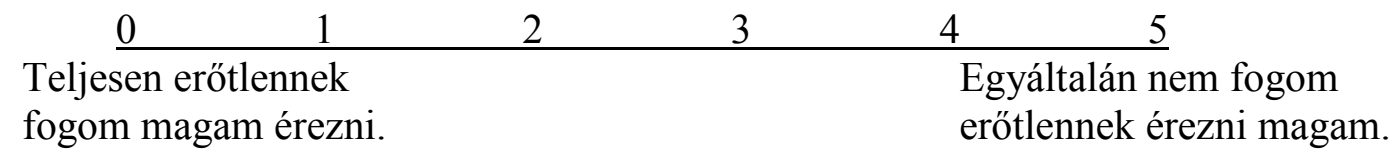

9

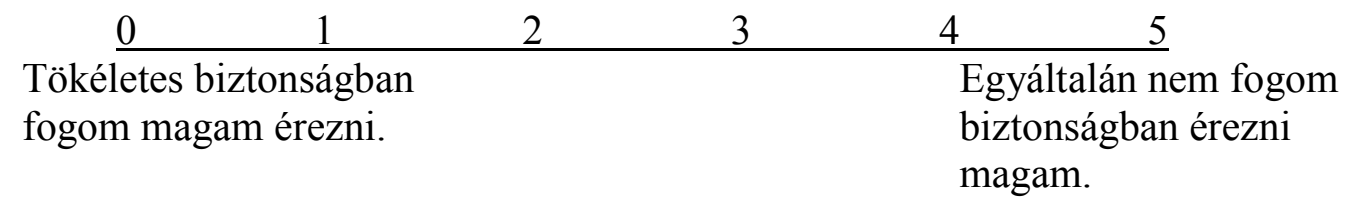

10

Teljesen önállónak fogom

$2 \quad 3$

$4 \quad 5$

magam érezni.

Egyáltalán nem fogom önállónak érezni magam.

11

$\underline{0} \quad 1$

Rendkívül lehangolt $\quad$ Egyáltalán nem leszek

leszek.

lehangolt.

12

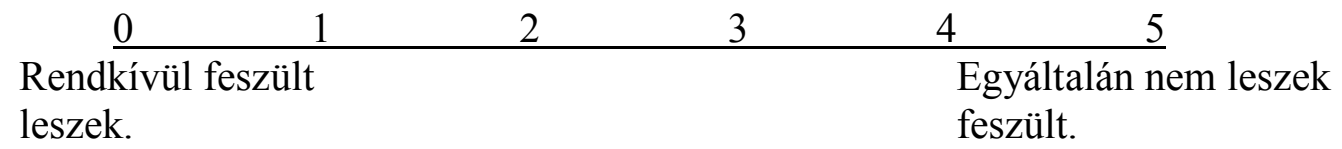

13

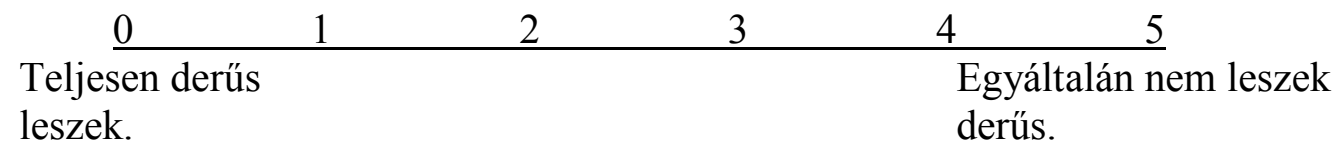

14

\begin{tabular}{llllll}
0 & 1 & 2 & 3 & 4 & 5 \\
\hline & & & & Egyáltalán nem fog
\end{tabular}

fog eltölteni. büszkeség eltölteni.

15

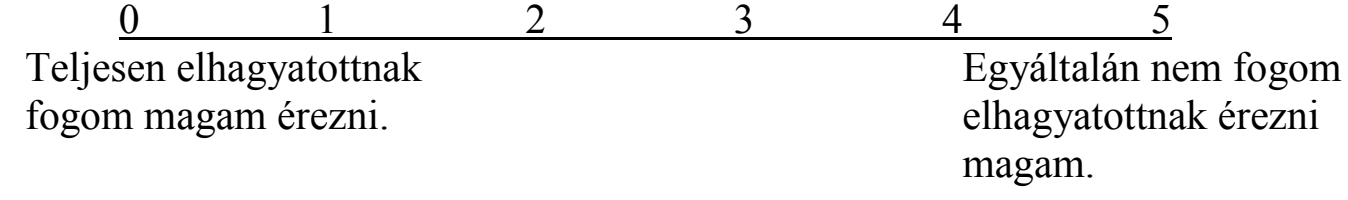

16

Teljesen összeszedett

leszek.

$3 \quad 4 \quad 5$

Egyáltalán nem leszek összeszedett.

17

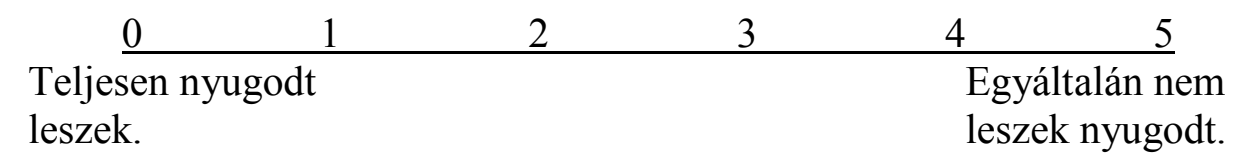

18

0

1

2

3

$4 \quad 5$

Tökéletes boldogság

fog eltölteni.

Egy cseppet sem

leszek boldog. 
III Mit gondol, mit fog érezni a vajúdás és a szülés alatt?

19

$\begin{array}{lllll}0 & 2 & 3 & 4 & 5 \\ \begin{array}{l}\text { Nagyon erös } \\ \text { rémület lesz rajtam úrrá. }\end{array} & & & & \text { Egy csepp rémületet } \\ \text { sem fogok érezni. }\end{array}$

20

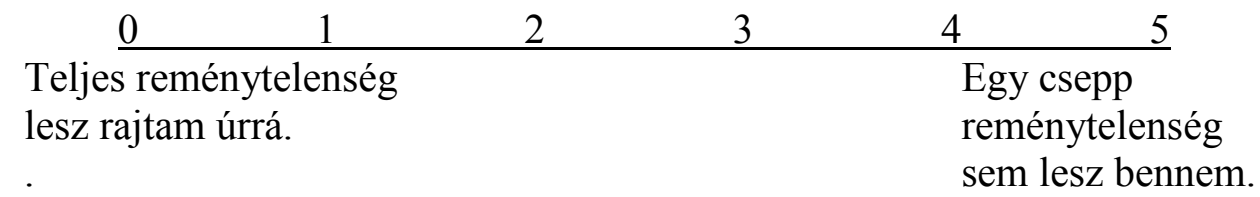

21

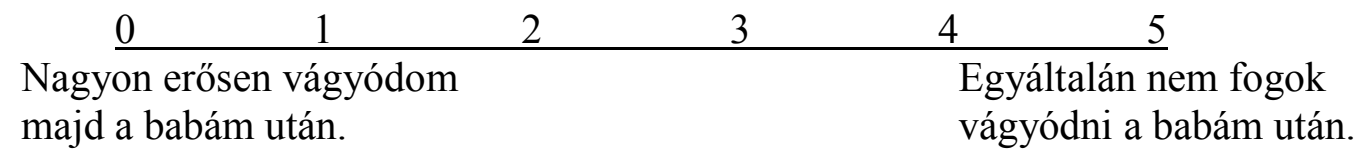

22

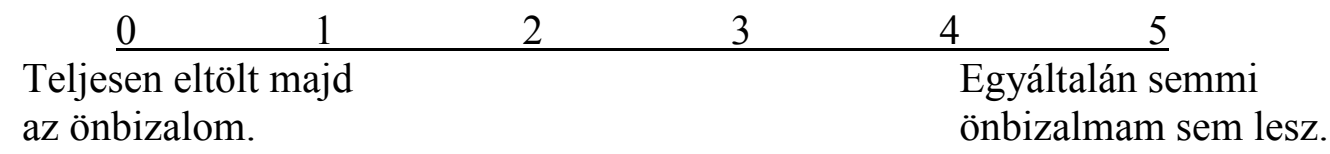

23

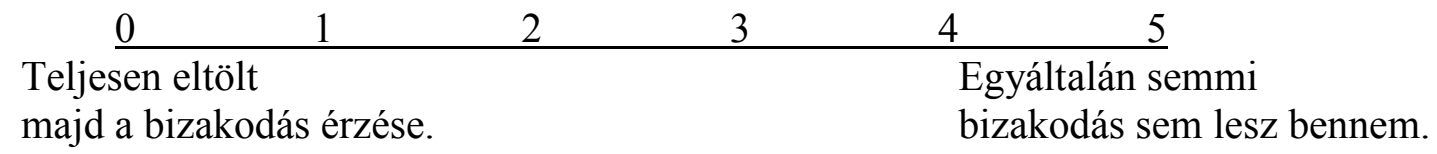

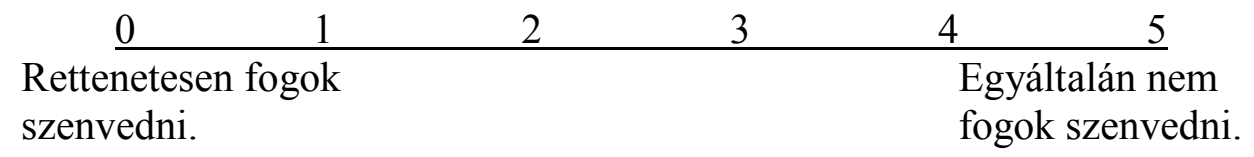

IV Mit gondol, mi fog történni, amikor a legintenzívebben fog vajúdni?

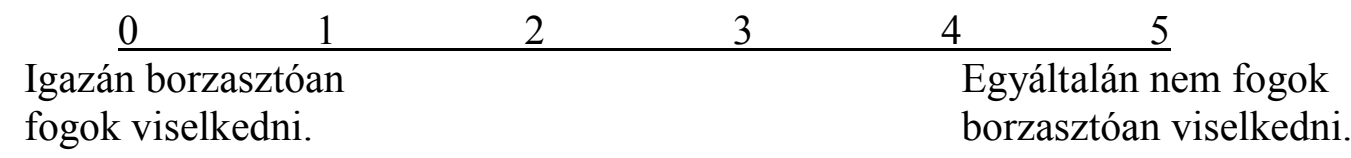

0

Hagyni fogom, hogy a testem

teljesen átvegye

az irányítást.
$4 \quad 5$

Egyáltalán nem fogom hagyni, hogy a testem átvegye az irányítást.

27

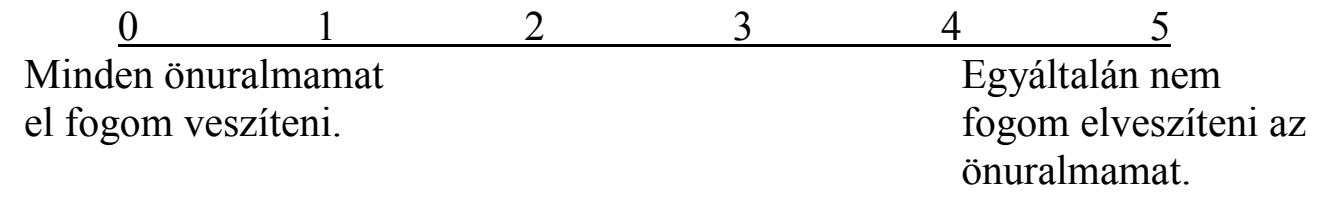


V Hogyan képzeli azt a pillanatot, amikor megszüli a babáját?

28

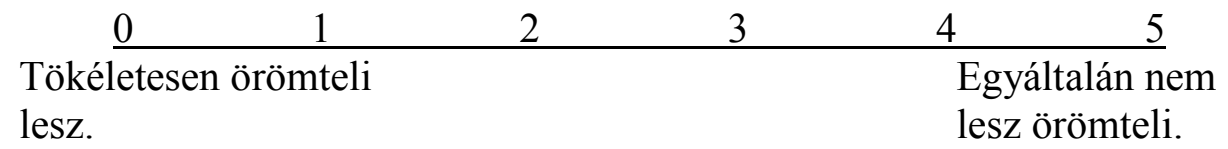

29

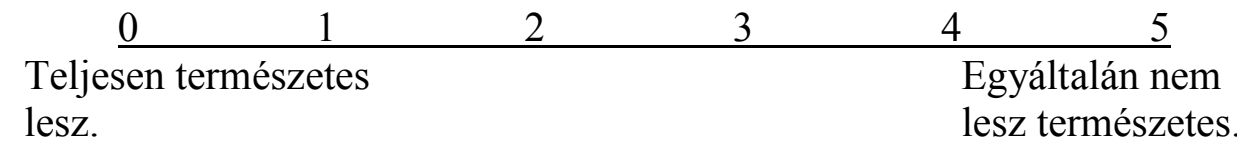

30

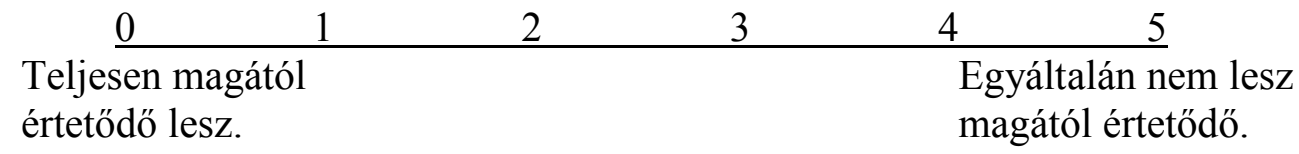

31

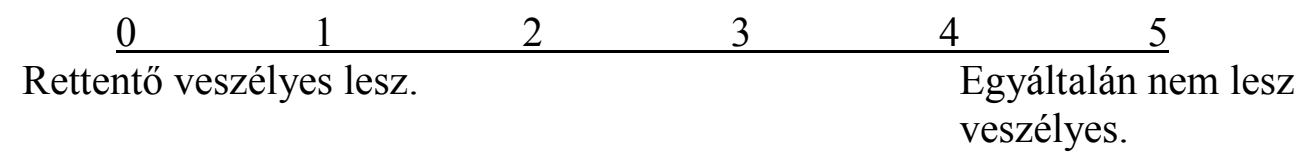

VI Voltak-e az elmúlt hónapban a vajúdással illetve a szüléssel kapcsolatos rémképei, mint például:

$32 \ldots$ hogy a gyermeke meg fog halni a vajúdás vagy a szülés során?

Soha. $\begin{array}{llllll}0 & 1 & 2 & 3 & 4 & 5 \\ & & & & & \text { Nagyon gyakran. }\end{array}$

$33 \ldots$ hogy gyermekének baja fog esni a vajúdás vagy a szülés során?

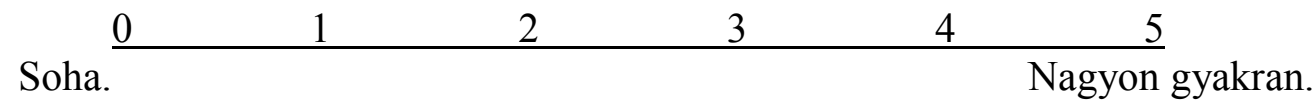

Most kérem, ellenőrizze, hogy minden kérdésre válaszolt-e! 


\section{The Wijma Delivery Expectancy/Experience Questionnaire}

(W-DEQ) version A

\section{INSTRUCTION}

(C) 2005 K. Wijma

This questionnaire is about feelings and thoughts women may have at the prospect of labour and delivery.

The answers to each question appear as a scale from 0 to 5 . The outermost answers

( 0 and 5 respectively) correspond to the opposite extremes of a certain feeling or thought.

Please complete each question by drawing a circle around the number belonging to the answer which most closely corresponds to how you imagine your labour and delivery will be.

Please answer how you imagine your labour and delivery will be - not the way you hope it will be.

I How do you think your labour and delivery will turn out as a whole?

1

$\begin{array}{lllll}0 & 1 & 2 & 3 & 4 \\ \begin{array}{l}\text { Extremely } \\ \text { fantastic }\end{array} & & & \begin{array}{l}\text { Not at all } \\ \text { fantastic }\end{array}\end{array}$

2

$\begin{array}{lllll}0 & 1 & 2 & 3 & 4\end{array}$

II How do you think you will feel in general during the labour and delivery?

3

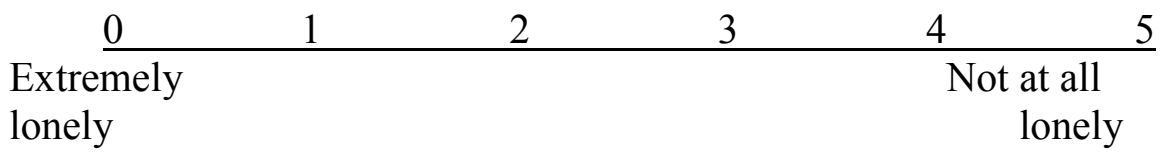

4

$\begin{array}{llllcr}0 & 1 & 2 & 3 & 4 & 5 \\ \begin{array}{l}\text { Extremely } \\ \text { strong }\end{array} & & & \text { Not at all } \\ \text { strong }\end{array}$

5

$\begin{array}{lllll}0 & 1 & 2 & 3 & 4 \\ \begin{array}{l}\text { Extremely } \\ \text { confident }\end{array} & & & \begin{array}{l}\text { Not at all } \\ \text { confident }\end{array}\end{array}$

6

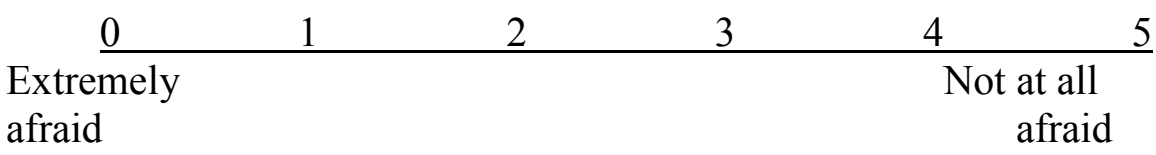

7

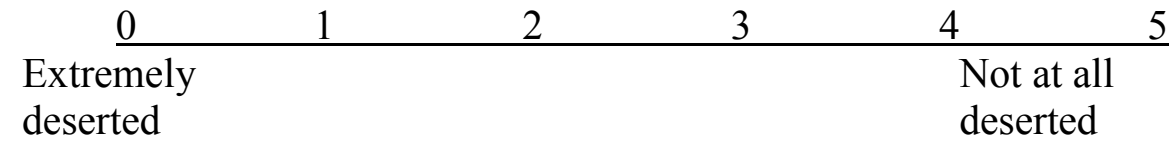


II How do you think you will feel in general during the labour and delivery?

8

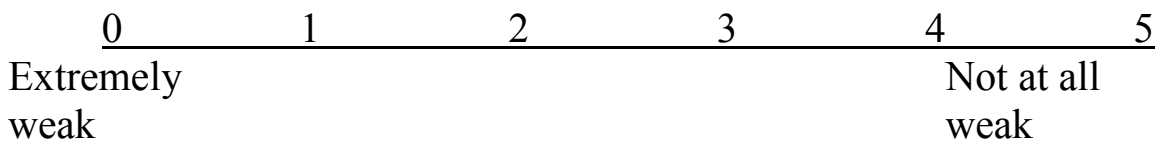

9

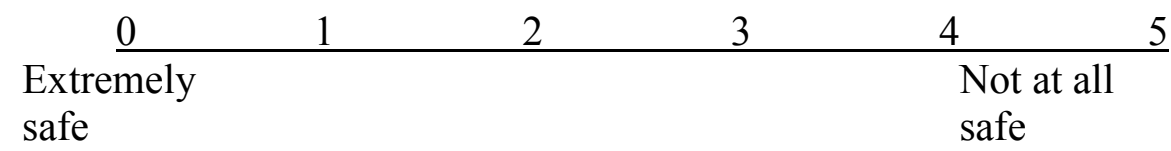

10

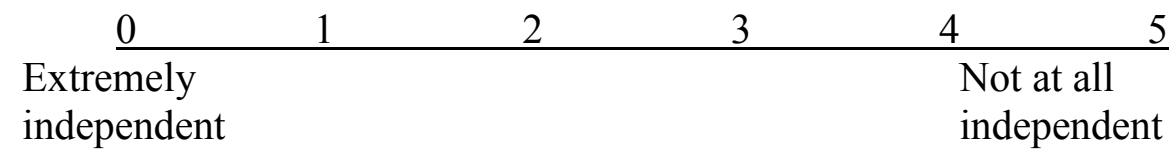

11

$\begin{array}{lllll}0 & 1 & 2 & 3 & 4\end{array}$

12

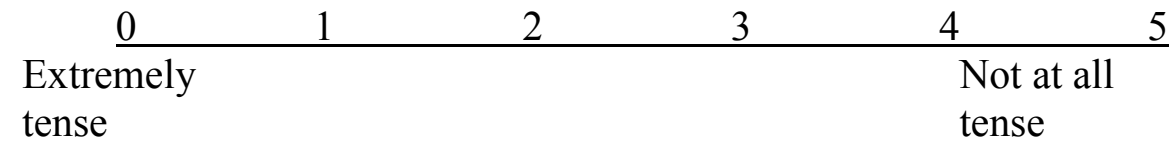

13

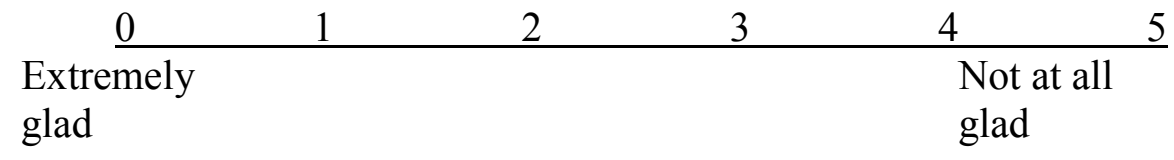

14

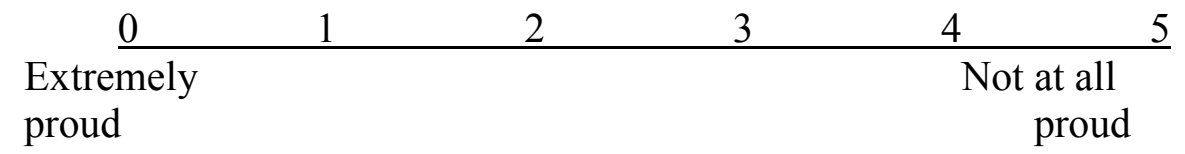

15

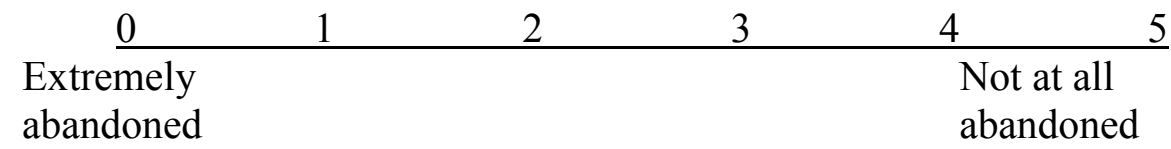

16

$\begin{array}{lllll}0 & 1 & 2 & 3 & 4\end{array}$

17

$\begin{array}{lllll}0 & 1 & 2 & 3 & 4 \\ \begin{array}{l}\text { Extremely } \\ \text { relaxed }\end{array} & & & \begin{array}{l}\text { Not at all } \\ \text { relaxed }\end{array}\end{array}$

18

$\begin{array}{llllc}0 & 1 & 2 & 3 & 4\end{array}$


III What do you think you will feel during the labour and delivery?

19

$\begin{array}{lllll}0 & 1 & 2 & 3 & 4 \\ \begin{array}{l}\text { Extreme } \\ \text { panic }\end{array} & & & \text { No panic } \\ \text { at all }\end{array}$

20

$\begin{array}{lllll}0 & 1 & 2 & 3 & 4\end{array}$

21

$\begin{array}{lllll}0 & 1 & 2 & 3 & 4\end{array}$

22

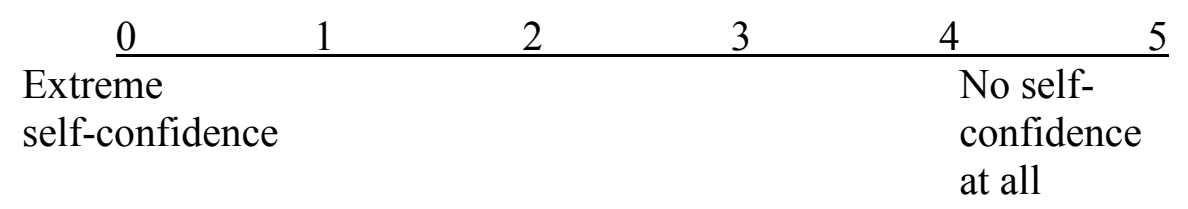

23

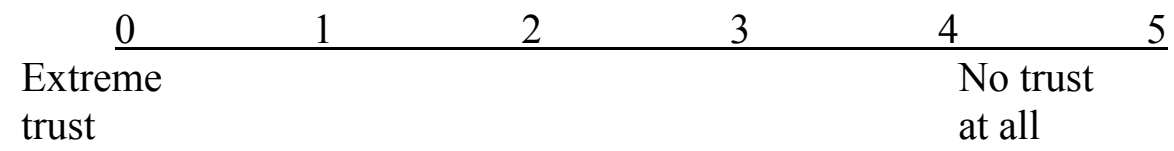

24

$\begin{array}{lllll}0 & 1 & 2 & 3 & 4 \\ \begin{array}{l}\text { Extreme } \\ \text { pain }\end{array} & & & \text { No pain } \\ \text { at all }\end{array}$

IV What do you think will happen when labour is most intense?

25

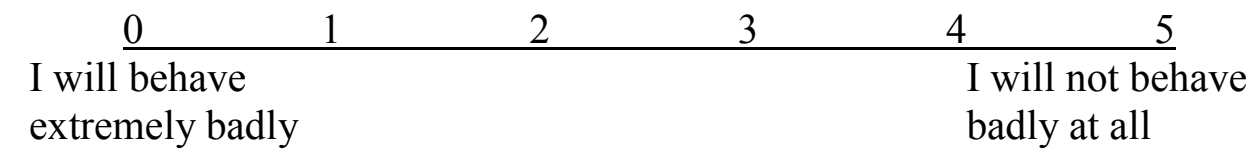

26

\begin{tabular}{llll}
\multicolumn{1}{l}{1} & 2 & 3 & 4
\end{tabular}

27

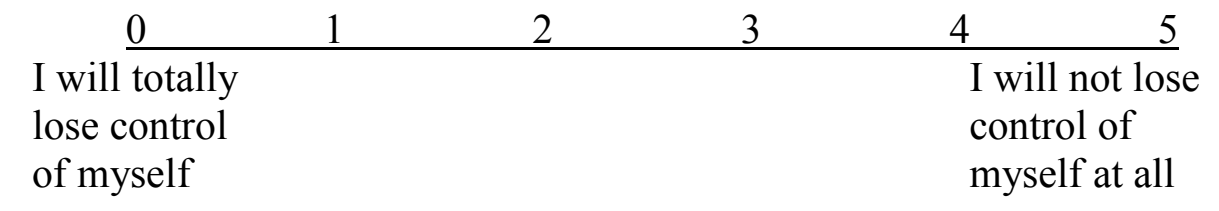


V How do you imagine it will feel the very moment you deliver the baby?

28

$\begin{array}{lllll}0 & 1 & 2 & 3 & 4 \\ \begin{array}{l}\text { Extremely } \\ \text { enjoyable }\end{array} & & & \begin{array}{l}\text { Not at all } \\ \text { enjoyable }\end{array}\end{array}$

29

$\begin{array}{lllll}0 & 1 & 2 & 3 & 4 \\ \begin{array}{l}\text { Extremely } \\ \text { natural }\end{array} & & & \begin{array}{l}\text { Not at all } \\ \text { natural }\end{array}\end{array}$

30

$\begin{array}{lllll}0 & 1 & 2 & 3 & 4\end{array}$

31

$\begin{array}{lllll}0 & 1 & 2 & 3 & 4 \\ \begin{array}{l}\text { Extremely } \\ \text { dangerous }\end{array} & & & \begin{array}{l}\text { Not at all } \\ \text { dangerous }\end{array}\end{array}$

VI Have you, during the last month, had fantasies about the labour and delivery, for example.....

32 ... fantasies that your child will die during labour/delivery?

$\begin{array}{rrrrrr}0 & 1 & 2 & 3 & 4 & 5 \\ \text { Never } & & & & & \text { Very often }\end{array}$

33 ... fantasies that your child will be injured during labour/delivery?

$\begin{array}{rrrrrr}0 & 1 & 2 & 3 & 4 & 5 \\ \text { Never } & & & & & \text { Very often }\end{array}$

Would you please now check that you have not forgotten to answer any questions? 


\section{Appendix 4 (Hungarian version)}

1. Életkora (betöltött éveinek száma):

2. Milyen kapcsolatban áll magzata édesapjával?
a. Házastársam.
b. Élettársam.
c. Külön élünk, de tartjuk a kapcsolatot.
d. Nem tartjuk a kapcsolatot.

3. Lakhelye:
a. Megyeszékhely
b. Nagyváros
c. Falu, község
d. Tanya, külterület

4. Legmagasabb iskolai végzettsége:
a. Kevesebb, mint 8 általános
b. 8 általános
c. Szakmunkás képző
d. Érettségi
e. Felsőfokú végzettség

5. Hogyan ítéli meg jelenlegi anyagi helyzetét?
a. Kissé átlagon aluli
b. Átlagon aluli
c. Teljesen átlagos
d. Átlag feletti
e. Jóval átlag feletti

6. Tervezett volt-e ez a terhesség?
a. Igen.
b. Nem.

7. Milyen hosszan vágyódtak a terhesség után: mennyi idő telt el az elhatározástól a magzat megfoganásáig?
a. Kevesebb, mint fél év
b. 6 hó -1év
c. 1-2 év
d. 2-5 év
e. Több, mint 5 év

8. Spontán, természetes módon fogant-e jelen terhessége?
a. Igen.
b. Inseminatio útján.
c. Lombikbébi program keretében (IVF-ET).

9. Dohányzik-e?
a. Nem.
b. Igen.

10. Van-e választott orvosa, aki majd jelen lesz a szülésnél?
a. Igen, van.

b. Nem, nincs.

11. Van-e választott szülésznője, aki majd jelen lesz szülésénél?
a. Igen, van.
b. Nem, nincs.

12. Várhatóan lesz-e kísérője a szülésnél?

a. Igen, mégpedig:.

b. Nem. 


\section{Appendix 4 (English version)}

1. Age (years):...

2. Civil status:
a. married
b. cohabiting
c. living separately from partner, but keep in touch
d. living separately from partner

3. Place of residence:
a. large town
b. smaller town
c. village
d. farm

4. Level of education:
a. 8 years $>$
b. 8-11 years
c. 11-12 years
d. graduated from secondary school
e. college or university degree

5. Self-rated financial status
a. very much below average
b. slightly below average
c. average
d. slightly above average
e. very much above average

6. Was this pregnancy a planned one?
a. yes
b. no

7. How long did it take from the decision to get pregnant to the conception?
a. less than six months
b. 6 months -1 year
c. 1-2 years
d. 2-5 years
e. 5years<

8. Mode of fertilization:
a. spontaneous
b. arteficial insemination
c. in vitro fertilization

9. Tobacco habits:
a. non-smoker
b. smoker

10. Are you planning to be seen by private obstetrician at delivery?
a. yes
b. no

11. Are you planning to be seen by private midwife at delivery?
a. yes
b. no

12. Do you expect to be unaccompanied at delivery?
a. yes, the following person(s):.........
b. no 